\title{
65 $S_{38}$
}




\section{wor a saregerey}

collow Mon

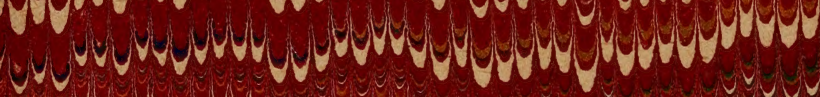

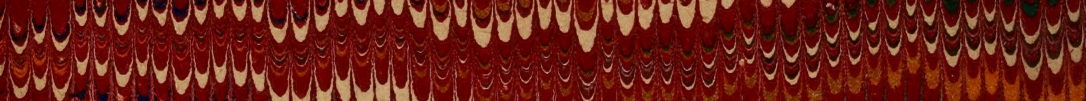
you

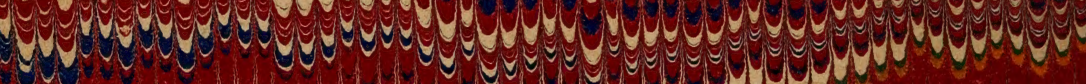

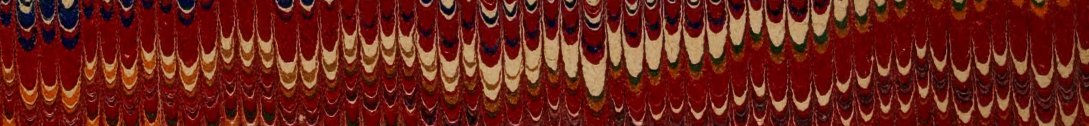
arylus?

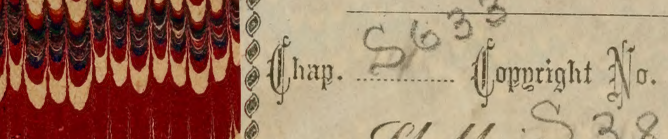
wull: Sholf $\$ 38$ LIBRARY OF CONGRESS. DUNENU arayey

UNITED STATES OF AMERICA.

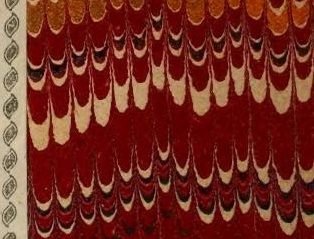

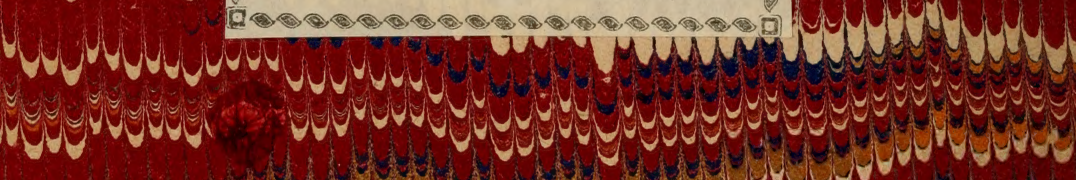

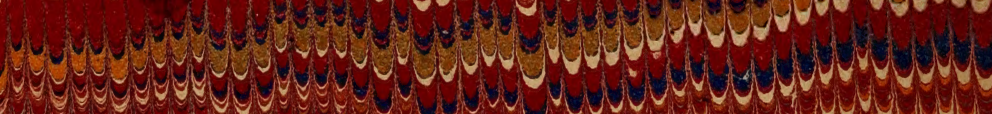

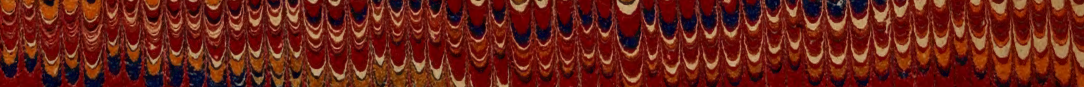

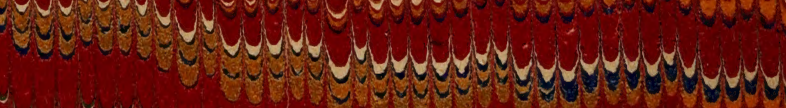

con do a 
W.1. .

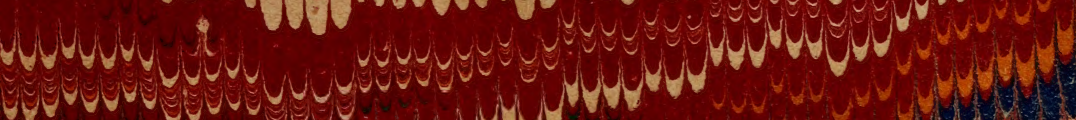

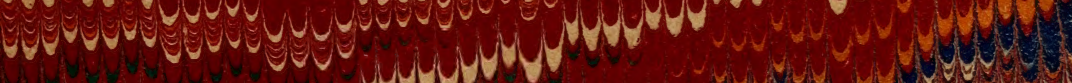
aver

colve man Wow to whendury whym

owney are cos alw

(t)

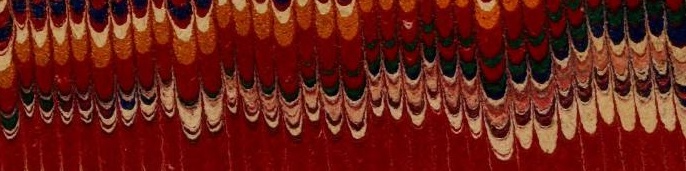

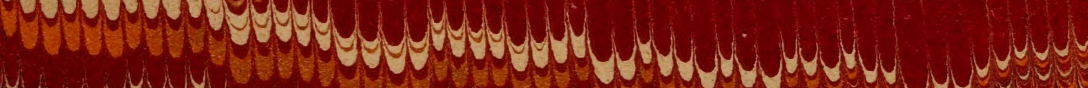

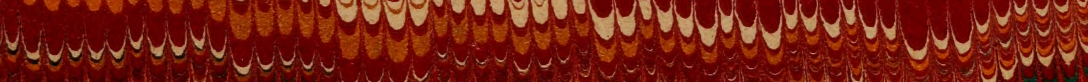

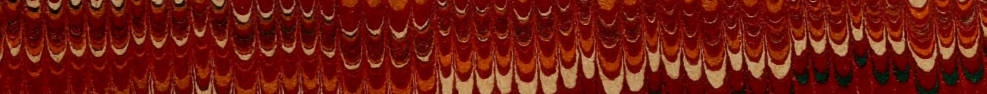

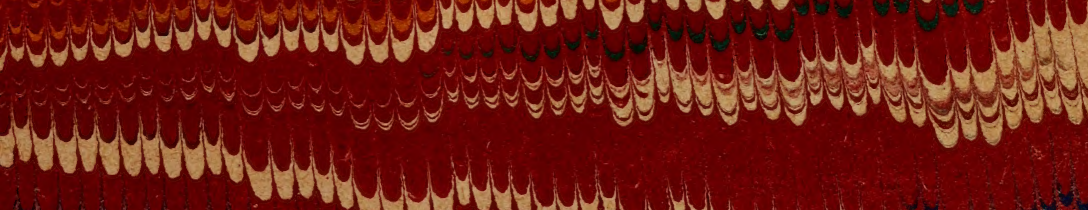

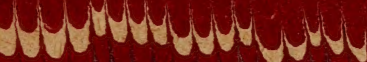







A BOOK OF INSTRUCTION FOR EVERY FARMER AND HORTICULTURIST.

\section{THE NEW FARMER'S GUIDE:}

SHOWING BY

EXPERIMENTS OF THE TRIAL FARMS IN EUROPE, THAT WITH $A$ JUDICIOUS $\triangle$ PPLICATION OY

\section{CHEMICAL FERTILIZERS,}

THE YIELD OF THE PRINCIPAL AGRICULTURAL CROPS MAY BE DOUBLED OR TREBLED;

ALSO GIVIsG

SIMPLE AND EASY METHODS

FOR THE

NITRIFICATION OF THE SOIL.

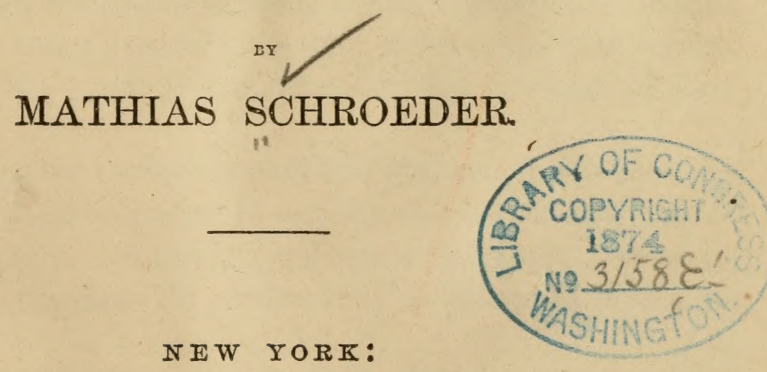

BAKER \& GODWIN, PRINTERS,

No. 25 PẠK RoW. 
Entered, according to Act of Congress, in the year 1874,

BY MATHIAS SCHROEDER,

In the Office of the Librarian of Congress, at Washington.

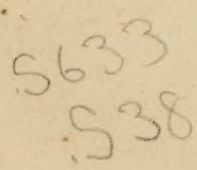




\section{PREFA CE.}

Trie following pages are submitted to the attention of American farmers as a compendium of the latest and most reliable information obtained from the experiments and trials made by European agriculturists. The opinions of many of the ablest and most intelligent writers are given, not with a view of unduly exalting the merits of chemical fertilizers, but simply with the intention of showing how these fertilizers may, with the exercise of proper judgment and care in their manufacture and application, become of the greatest value in increasing the productiveness of the soil.

There has been much misunderstanding as to the relative value and excellences of farm-yard manures and chemical fertilizer's. I do not advocate the extreme views of Mr. George Ville (from whose works I have quoted) as to the comparative uselessness of farm-yard manure, although, at the same time, I should not wish to be understood as undervaluing the general excellence of the writings of that gentleman.

1 My object is rather to hold the balance fairly between the two kinds of manure, to explain the active qualities of each, and point out the ingredients which must always be present in manures in order that a favorable result be attained.

In this way I seek to convince the American farmer that, in a great majority of cases, it will be greatly to his advan- 
tage to use the fertilizers, if they are properly manufactured from pure materials:

I have also thrown out hints upon a variety of topics, which will be found of some importance to agriculturists. More especially do I direct attention to the interesting: questions connected with a discussion of the nitrification of the soil-a matter that has recently obtained a good deal of notice, but which needs to be much better understood by farmers generally.

As a practical and theoretical agriculturist for a number of years, I feel anxious that the discussions introduced in these pages shall receive general attention; and with that view, I invite the co-operation of members of Farmers' Clubs and other kindred associations in the dissemination of the information they contain, which I have endeav. ored to present in such a form as shall be readily under. stood, and be easily applied to practical use in the improve. ment of our systems of cultivation of the soil.

Mathias Schroeder. 


\section{CONTENTS.}

Preface.................................... $3-4$

Experiments at the French "School of Manures."-Lecture by George

Ville............................... $7-20$

Explanation of Terms.-Vegetable and Animal Kingdoms........ 21-22

Composition of Chemical Substances.................... 23

Elements required in a Soil to produce Grent Fertility. . . . . . . 21-28

Efiects of Tarious Kinds of Manure Explained.-Mr. Ville's Theories

Discussed...............................29-32

Absorption of Atmospheric Nitrog n by Vegetation........... $83-38$

The Passage of Gases through the Vegetable Colloidal Membrane... . 38

Results of an Investigation in Fast India._Nitrates. _Soda . . . . . $39-42$

Researches of Boussingault on the Nitrification of the Soil.-Percent.

ages of Saltpetre in the Soil.-The Nitre Deds of Algeria...... 43-45

Jeauncl on Nitrates and Nitrites................... 40

Analytical Tables compiled by Emil Wolf.............. 47-56

Comparative Quantitics of Potash, Lime, Dhosphoric Acid, and Nitro-

gen, ill an arerage crop of the principal Agricultural Products of

Germany............................... 57-58

Why Amcrican Agriculturists O'ject to Chemical Fertilizers. ..... 59-60

Approximate Exhaustive Time Table of Manures and Fertilizers, \&c.,

By Count Von Lippe-Wiehenfeld................... 61

Stassfurt Potash Salts-of what they consist, \&c............ 62

Artificial Plaster, or Sulphate of Jime................. 63

Fermentation of MIanures and Nitrification of the Soll..........64-65

Deep and Shallow Plowing.......................66-67

Why Wet Lands should be Plowe 1 in Beds................ 68

Synopsis of Agricultural Trials made at Proskau, Germany . ...... 69-70

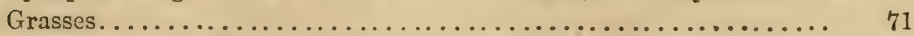

Potato Trials, with Turf and Inorganic Matter............. 72-73

Trials on Sugar Beets, with Turf and Fertilizers............ 74-75 
Method of Determining the Quantity of Starch in Potatces....... 76-77 Address of Baron Justus Von Liebig. ................. $78-79$ Wheat Trials by Messrs. Lawes and Gilberts............. 80 Efiect of Various Kinds of Manure on Oats and Barley......... 81 Miscellaneous Topics: Plow and Cart Horses.-Live Stock, Butter and Cheese Factories.-Canals for Irrigation and Transportation.-All Seeds for Planting should be imported Free of Duty . . 82-84 Conclusion................................ 85 87 French Kilogrammes reduced to U. S. Pounds............. 88 


\section{EXPERIMENTS}

AT THE

\section{FRENCH SCHOOL OF MANURES.}

BY GEORGE VILLE.

A series of annual conferences are held at Vincennes, France, in connection with a national association known as the "School of Manures," at which the attendance usually includes a considerable number of the most eminent French farmers, as well as gentlemen from other countries interested in the questions discussed. At one of these conferences a very valuable paper, conveying information of much interest, was read to the assembled agriculturists (among whom was M. Durny, Minister of Public Instruction) by Mir. George Ville, then superintendent of the institution, under the appointment of the late Emperor, Napoleon III. The main portions of this essay, which was published at the time in the Joumal Officiel de l'Empire Français, have been translated.

We present Mir. Ville's lecture to the American public without any comment, agreeing in the main with the principles laid down, although, in another portion of this work, it has been necessary to state points on which there is reason to believe this very able agriculturist is incorrect in his assertions. 


\section{MR. VILLE'S LECTURE.}

The year 1869 will be prominent in the annals of agriculture for the progress that has been made, and more especially for the number of experiments which have had for their object the determining of the nature and effect of the various chemical manures. By a brief review, we shall be able to form an idea of the importance of the new systems which have been inaugurated by the Vincennes school.

Nearly six hundred experiments have been conducted, and these have been made in every portion of our land, and under the most varied circumstances, so that they have encountered all the unfavorable chances which are met with in practical agriculture. Not to multiply details, I will confine myself to a statement of the results of these experiments in relation to the three most important plants of our climate-wheat, beet and potatoes.

As many as 138 experiments were made on wheat, the results of which are summed up in the following tables:

921 kilogrammes of chemical manure produced, on an average, of grain per hectare 29 hecto. 73-100 while with

40,203 kilogrammes of farm manure, the crop was only..................... 21 hecto. $6-100$

This shows an excess, in round numbers, of $8 \frac{1}{2}$ hectolitres of grain per hectare in favor of the chemical manure. But that is not all: from a classification of these 138 experiments we find that the variations of crop were as follows:

No. of Experiments.

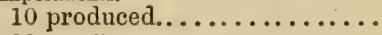

22

20

22

26

38
Crop of Wheat per Hectare.

$\begin{array}{cc}\begin{array}{c}\text { Chemical Manure. } \\ \text { Hectolitres. }\end{array} & \begin{array}{c}\text { Farm Manure. } \\ \text { Hectolitres. } \\ 46.50\end{array} \\ 35.90 & 39.22 \\ 31.20 & 26.84 \\ 27.42 & 19.31 \\ 22.44 & 14.50 \\ 15.00 & 14.50 \\ & 12.03\end{array}$


Or, to put the same statement in a simpler form, out of every four trials, the crops have been in the following; proportions:

No. of Experiments.

Two produced............

One

One

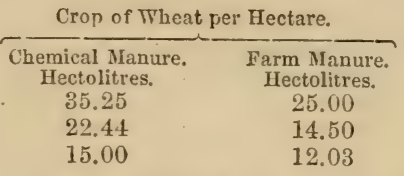

Hence, it will be seen that, with chemical manure, the prospect would be two large crops, one good average crop, and one middling crop, out of four plantings; while, with farm manure, the result from the same number of trials wonld be an average crop twice, and a middling crop twice.

The experiments with beet lead also to the same conclusion. There were 190 trials, and

1,326 kilo. of chemical manure gave an average per hectare of ................... 51,948 kilo. while

50,650 kilo. of farm manure gave a crop, per hectare, of only.................. 41,811 "

Excess in favor of chemical manure... $\overline{10,137}$ "

When we proceed to classify these trials, the result shows a contrast not less significant than in the case of wheat, as to the proportionate efficiency of the two agents:

No. of Experiments.

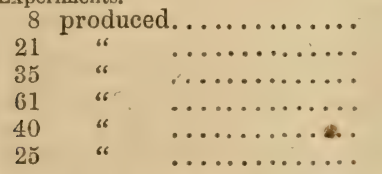

Crop of Beet per Hectare.

$\begin{array}{cc}\text { Chemical Manure. } & \text { Farm Manure. } \\ \text { Kilogrammes. } & \text { Kilogrammes. } \\ 91,664 & 70,149 \\ 63,507 & 49,900 \\ 53,673 & 43,670 \\ 43,640 & 34,784 \\ 35,373 & 28,920 \\ 24,433 & 23,453\end{array}$

Thus, in four plantings, the proportion with chemical manure is two and one-half increased crops, one average crop, and one-half middling crop; while, in the three first plantings, there was an excess of 10,000 kilogrammes over the crops obtained by farm manure. 
With potatoes, 83 experiments were made, with similar satisfactory results:

No. of Experiments.

17 produced.

16

26

24

"6 6

" d...............

(..............

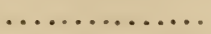

\begin{tabular}{|c|c|}
\hline \multicolumn{2}{|c|}{ Crop of Potatoes per Hectare. } \\
\hline $\begin{array}{c}\text { Chemical Manure. } \\
\text { Kilogrammes. } \\
38,271\end{array}$ & $\begin{array}{c}\text { Farm Manure. } \\
\text { Kilogrammes. } \\
30,812\end{array}$ \\
\hline 24,288 & 16,871 \\
\hline 17,266 & 14,921 \\
\hline 11,119 & 11,633 \\
\hline
\end{tabular}

The average crop per hectare would, therefore, be as follows :

Kilo.

Crop of Potatoes per Hectare.

1,090 of chemical manure Kilogrammes.

39,946 of farm manure.

22,736

Excess in favor of chemical inanure.

4,177

\section{EXPERIMENTS IN THE COLONIES.}

The results which have been obtained from experiments in the colonies with the sugar-cane are no less striking. The yield of the cane is of two kinds, viz., the crop of the first year, derived from a planting of cuttings, known as planted canes; and the canes derived from the mother stock in succeeding years, which are called sprouts. The firt crop is generally the largest.

I am indebted to the Marquis de Rancougne, proprietor: of one of the most important sugar manufactories in Guadiloupe, for an abstract of the average yield of a plantation of 21,000,000 kilo. (both planted canes and sprouts), which is placed at 34,000 kilo. From the experiments which have been carried on at Guadeloupe by M. de Javrun, during the last three years, it appears that, with chemical manure, the cane yielded the first year, 84-,782 kilo., and the second year, 26,875 kilo. This was an average of 55,000 kilo. per hectare, instead of 34,000 . What is more remarkable still, moreover, is that, where the chemical manure was 
used, the canes gave $17 \frac{80}{100}$ per cent. of sugar, while those cultivated without manure produced only $11_{\frac{5}{100}}^{5}$ per cent.

The importance of these results, in an economical point of vicw, is evident; but I leave that to be developed by the practical men who made the experiments.

M. Autier, who carries on the farm of Saint Denis, near Lechesne, in the Ardennes, with great ability, writing me on the 13th of February, 1862, says :

"My farm has the following distribution of crops:

Beet, with 50,000 kilo. of manure.

Wheat.

Clover.

Oats.

Hay (annual).

Colza, with 30,000 kilo, of manure.

Wheat.

"With these 80,000 kilo. of manure, divided over a period of seven years, I have obtained, up to the present time:

17 to 20 hectolitres of wheat per hectare.
30 to 35 " " oats ". "
16 to 17 " colza " "

"With a supplementary expense of 100 francs per hectare for chemical fertilizers, my crops have increased the last year in the following ratio:

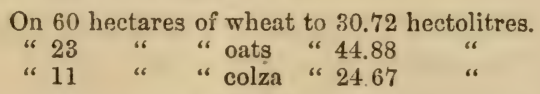

"The soil in the neighborhood surrounding my farm is rich-at least double the value of my land; but nowhere are chemical fertilizers used. The crops which I have obtained through their application have exceeded by 30 per cent. the crops of my neighbors."

M. Debaine, a cultivator at St. Remi, in the department of Seine and Oise, gives the following words of advice to the farmers of Beance, whose vast tracts of land are poorly 
manured: "Concentrate your manure in the half of the ground." And to other's he says: "Employ chemical fertilizers, and you will double your crops."

M. Schatteumann, the oldest and one of the most experienced of French agriculturists, recently dead, goes even further. "France," said he, "must lose no time in making. all possible use of chemical fertilizers, so that she may be enabled to supply her own wants, and not be surpassed by other nations."

Indeed, no one doubts the fact that with chemical fertilizers crops are always more abundant than with dungheap manures; but some people raise the objection that they are not really fertilizers - that the only action of the so-called chemical fertilizers is to dissolve the elements of fertility contained in the soil, and thus, sooner or later, exhaust it. Others raise the objection that these fertilizers cannot take the place of farm-yard manures, because they are deficient in certain qualities which are always found in the latter, and which plants cannot do without. What amount of truth is there in these assertions? Absolutely none! In proof, take an analysis of farm-yard manure. We find, in the first place, 80 per. cent. of water; but it is not to water that it is indebted for its good qualities. The useful properties of farm-yard manures are, therefore, to be found in the remaining twerty parts. But the value of these is considerably reduced when other necessary deductions are made: 13.29 per cent. must be subtracted on account of the woody fibres and straw, which contain hardly any fertilizing properties. Silica, oxide of iron, sulphuric acid, chlorine, soda, represent 5.07 per cent., and all of these the worst soils are full of. The really active properties contained in farm-yard manures are, therefore, reduced to 1.64 per cent. 
RECAPITLLATION.

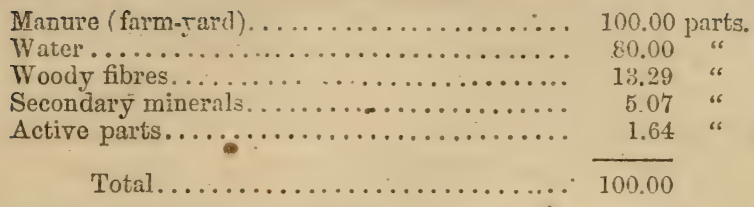

The active parts (1.61) are composed as follows:

Azote................................ 0.41

Phosphoric acid........................ 0.18

Potassium.......................... 0.49

Lime $. . . \ldots \ldots \ldots \ldots \ldots \ldots \ldots \ldots \ldots, 0.56$

1.64

These are the very four suibstances of which mineral manures are composed.

But there is another objection jet. Is it really certain that in the 13.29 per cent. of moody fibres there is nothing of any real value as a fertilizer? Wo reply, Nothing is more certain. These fibres are, in fact, composed only of carbon, hydrogen and oxygen, and each of these the plant can obtain in sufficient quantity from other sources-the carbon from the carbonic acid of the air, and the hydrogen and oxygen from the rain-water. Let some shavings or sawdust be allowed to rot in a manure pit, and what do we get? A manure which is altogether wortliless, of a similar nature to turf, which is entirely inefficacious as a fertilizer. Now, it is not reasonable to expect that carbon, hydrogen and oxygen in straw will be of any value, when it is known that the same agents in other substances are utterly worthless. Geology confirms us in this conclusion. In the order of creation, vegetables were the first representatives of life on the surface of the globe, and the coal deposits, which are so extensive, were formed from the decomposition of the primeval forests. At that remote period, regetation possessed a luxuriance and vigor of growth which has since 
greatly decreased. The calamites and the lepidodendrons of those primitive ages grew to more than 45 feet in height, and formed extensive forests, but they are represented today by simple plants - the lycopodes and the shave grasses. Now, did the lepidodendrons and the calamites find in the soil any substances composed of carbon, hydrogen and oxygen analogous to the humids? It could not have been so, for the presence of these substances would necessarily presuppose an anterior creation. It is evident, then, that the new flora derived its nourishment from other sources than the substances which many now regard as highly productive of fertility, but which we declare to be altogether worthless. Carbon, hydrogen and oxygen cannot be indispensable to fertility now, for vegetation was much more luxuriant at a period when the soil was altogether devoid of them.

Another objection may be urged-that I have struck out, from among the active parts of farm-yard manures, silica, chlorine, sulphuric acid, oxide of iron, soda and magnesia; these I call secondary minerals, and they make up 5.07 per cent. of this manure. These substances are not useless in the promotion of vegetable life; on the contrary, plants cannot do without them. Why, then, should they be left out of the calculation? For this reason: that the very worst soils possess them in abundance. Let them either be added or taken away from the manure, and its action as a fertilizer remains the same. Why, therefore, should any ingredients be introduced which are of no real value?

We have now arrived at this point in the discussion: that farm-yard manures derives its active properties neither from its 80 per cent. of water nor from its 13.29 per cent. of woody fibres, nor yet from the 5.07 per cent. of second- 
ary minerals ; but only from its azote, phosphoric acid, pctassium, and lime, which form $1 \frac{64}{100}$ per cent., and of which our chemical fertilizers are also composed. Hence, it follows that the superiority of chemical manures-demonstrated by the experience of large cultivators-is clearly established and borne out by the analysis of chemical fertilizers and farm-yard manures; and this fact also becomes clear-that, in spite of the difference in the quantity and form, the active substances are one and the same, although, in farm-yard manures, there are a number of ingredients which are utterly worthless, and which, in the case of chemical fertilizers, are carefully excluded. Can there any longer be a shadow of doubt in the matter?

Another argument may be used which will throw still greater light upon the subject. If the venerable Mathieu de Dombasles had been told, some thirty years ago, that it was pcssible, through the use of certain chemical products, to regulate the process of vegetation as surely as if it were a simple piece of mechanism, that eminent agriculturist would have received the assertion with a smile of incredulity. Yet nothing can be more certain than that this has been done in the experiments carried on at Vincennes during the last ten years. The method by which this has been accomplished is as follows: All known vegetables, despite their different organizations and properties, are composed of a small number of elements, which remain always the same. These are divided into two groups, distinct in their nature and origin.

\section{Grodp I.}

Carbon, hydrogen, oxygen, azote.

\section{Group II.}

Manganese, phosphor, sulphur, chlorine, iron, silicum, magnesia, potassium, and sodium. 
These groups include all the bodies that are found in regetables, notwithstanding all differences of origin, form, and quality. Scientists conceived the illea that it was possible to create vegetation from these substances, just as they trould manufacture an ordinary commercial product, such as alum or soap. In order to meet all objections, the experiments were begun by selecting a worthless soil-calcined sand-that is to say, pure silica, which is an inert matter. This was watered with distilled water', which is pure water, and some wheat was sown. Vegetation, under these conditions, produced hardly the rudiment of a plant - the blade scarcely reached a height of 20 centimetres (about $\frac{r}{10}$ of an inch), with a diameter about the same as that of a medium-sized knitting needle. In the second experiment, some pure carbon was added, with no better results-only stunted plants were produced, as on the first occasion. On the third trial, a composition of car. bon, hydrogen, and oxygen was added, but still the result remained the same-the regetation languished, neither increasing nor diminishing. At this, of course, we are not at all surprised, as we know that all the carbon, hydrogen, and oxygen required by plants is furnished by the air and the rain.

The next step in the experiment was to add the ten mineral substances of the second group, in the following compositions, viz.: phosphate of lime, phospliate of magnesia, sulphate of lime, chloride of sodium, and the silicates of potash; of soda, of iron, and of manganese; but even then the result was no hetter. We are, therefore, led to the in-. evitable but singular conclusion that, of the fourteen elements which enter into the composition of veget? thirteen are wholly inert.

In pure sand, we have only a stunted vegetation; in 
sand containing an admixture of compositions of carbon, hydrogen, and oxygen, the same result; and no appreciable difierence when all the minerals are added. One more chance is left: let us try the effect of the application of azote in the form of ammoniacal salt, and this produces a certain action: the foliage of the plant becomes greener, and from its appearance when it begins to germinate, one might be led to suppose that the plant would continue to shoot up. But this is not so; first indications prove deceptive; the plant does not really flourish-some unfavorable influences seem to hang over it, and the crop turns out bad. There is an early promise of success, but the result is insignificant.

But now, as the last resource, let us persevere in the use of azote in the form of ammoniacal salt, adding also the ten minerals of the second gronp, and everything is changed at once. In this soil, which betore had appeared to be cursed and disinherited, in the absence of any fertilizing influence, a plant springs up, grows, cover's itself with flowers, and bears seed exactly similar in every respect to the seeds produced in good soil. And now, for the first time, science is the master of vegetation.

Observe, this is no mere theory; it is a successful exqueriment which speaks for itself; it is a fact, which every one must acknowledge to be worthy of notice.

But, to proceed a step further, let us endeavor to solve another problem. Since azote, associated with the-above ten minerals, produces in a sterile soil a crop equal to the growth in a naturally good soil, we will select a soil of calcined sand, and add to it a composition of azote, as an invariable ingredient, and also all the minerals, less one. Renew this trial as many times as there are minerals, so as to observe the influence of the withdrawal of each one. 
The resilt will be, that while with the composition of tho azote and all the minerals ineluded, the crop is $25 \mathrm{grammes}$ for 22 grains of seed, without the phosphate of lime the plant dies; the withdrawal of the potash reduces the crop to nine grammes, and the absence of the lime lessens the crop Irom 25 grammes to 18 . As to the secondary minerals, there is no need to speak further, as they are always found in abundance in the soil.

Thus we have established, against all possible denial, the proposition with which we started-that, by the action of certain chemical matters, vegetation may be produced; and we have proved, by trials made with kuown substances, that different degrees of fertility may be attained.

Now, let us proceed to inquire, what are the consequences that follow as the resuit of these experiments? If, by the aid of these chemical products, we can obtain, in a soil altogether deficient in the essentials for producing vegetation, resuits exactly similar to thuse produced by good soil, with the aid of manure, does it not follow that all the ingredients of farm manure, outside of the chemieal portion which I have described, are useless, or, at least, of secondary importance? I maintain that the identity of results cain only be traced to a similarity of causes.

Now, as to the last objection that may be urged, Is thore any doubt as to the correctness of the experiments themselves? let me say: M. Rieffel, manager of the school of Grarid-Jouan, had undertaken to superintend them, and they were conducted upon an uncultivated and worthless piece of land, ploughed up specially for the purpose. He sowcd two parallel crops of wheat and buckwheat, and obtrined the following results per hectare:

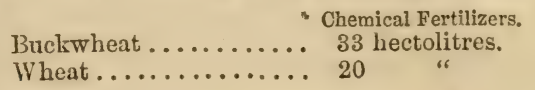

Farm Manure. 19 hectolitres. 16 
Chemical manure is thus seen to be superior to farm manure. On land without any manure, nothing at all was produced, no crop whatcver. It cannot, therefore, be said that the larger crops obtained by the use of the chemical fertilizers were the result of any substances inherent to the soil.

But this is not all. I said that the withdrawal of one of the ingredients in the chemical fertilizer annuls the effect of all the other parts. M. Ricffel made new experiments on this branch of the subject. He omitted the phosphate of lime-there was no crop; he employed the azote matter clone-no crop; he then tried the soil without any manure - still no crop; but when all the elements rere united, there was an aloundant crop. A11 my argument amounts to this: that I would advise agriculturists to have dono with discussions, and make triais for themselves. Many have done this, and the result of their experiments has been to prove that chemical mantre is from tro to three hundred times more productire than farm manure. The explanation of this is, that in farm-yard manure rre have the elements of the chmical fertilizer, but they are so mised up with useless substances as to retard their good effects.

Finalif, at my request, trials were made in producing vegetation with the chemical fertilizer alone, to the exclusion of all others, and the experiment succeeded admirably. So that there need be no donbt or hesitation. The most extensive agriculturai trials confirm our conclusions. The chemical fertilizers derive their efiects from the presence of the same elements as are in farm-yard manure; and ail that the latter contains, in excess of the former, is not nceded by the soil. In order to demonstrate this fact more clcarly, $\bar{i}$ have united in the same table a staternent of the composition of farm manure, of a plant, and of the soil taking as a 
unit of comparison the hectare. The manuring and crop of a hectare, and the arable layer spread over a hectarewhat does this table tell us? It shows that the dung-heap possesses about the same composition as the plant, which is quite natural, since it is derived from vegetable productions modified by animal digestion. Again, it shows that the ground contains enormous quantities of the minerals comprised in the second group, as silica, iron, manganese, sulphur, magnesia, etc., and thiis renders their presence useless in manure; while of azote, phosphoric acid, potash and lime, the amount is limited; therefore it is necessary to give them back to the ground to make it fertile, and that is why we make use of these four substances in the composition of our chemical manure.

We repeat, then, that azote, phosphoric acid, potash and lime are the elements which regulate the production of plants. Practical agriculture acknowledges this to be the case; the vegetation of the primitive ages confirms it, and the most precise and exact experiments derelop and sub-. stantiate the truth of this theory. But what I must further remark, although I have not before allucled to it, is that these four substances, though always necessary, do not fulfill an equal rôle with regard to all plants. According to the nature of the plant, one or other of these four substances manifests an action more or less decided on the crop-that particular substance dominates in the work of prodncing: the erop. In cereals and beet, the dominant agent is azote; while potash has the like effect in the case of beans, peas, and the leguminous plants. But we must always remember that this action never takes place without the aid and coöperation of the other three elements. If they are withdrawn, the one substance alone would have no action whatever. 


\section{THE VEGLTABLE AND ANIMAL KINGDOM.}

\section{EXPLANATION OF TERMS.}

With the majority of farmers, there would probably be some difficulty in understanding chemical experiments, unless an explanation were given of the technical and scientific terms used. As far as possible, the use of these terms is avoided throughout this pamphlet, but in order that everything may be rightly understood, and a correct judgment formed, I will now proceed to give such explanation as may be needed.

Chemists have proved that the vegetable and animal king doms consist entirely of fifteen substances, called chemical ingredients. These are divided into two groups. The tirst group comprises carbon, hydrogen, oxygen", and azote (or nitrogen); the second group consists of potash, soda, lime, magnesia, silica, alumin, iron, manganese, sulphur, phosphorus, and chlorine. These eleven included in the second group are inorganic matters, or salts contained in the ashes of plants, and therefore they are called the inorganic ingredients of plants. The first group are known as gases; although carbon is a solid matter, it is in the air, as a gas, called carbonic acid. By the wonderful laws of nature, each of these substances has such remarkable powers of attraction or affinity for the others, in forming chemical combinations or assimilations, they need only to be used judiciously to be available in bringing all kinds of plants to the highest degree of perfection. Now, for instance, we 
know that the air is composed of four-fitths nitrogen, onefifth oxygen, and $\frac{1}{2500}$ part carbonic acid, and that it holds from 1 per cent. to $2 \frac{1}{2}$ per cent. of water. We know that water is composed of one-ninth hydrogen and eight-ninths oxygen, the two gases chemically bound forming a liquid body. Potash, soda, lime and magnesia are combinations of oxygen, and these metals only. Ammoniacal gas is cuinposed of azote and hydrogen; and nitric acid is a compound of azote and oxygen. Common salt consists of chlorine and sodium - the first, a suffocating gas, the second, a metal that takes fire when brought in contact with water.

We know, also, that carbonic acid is composed of 23 per cent. of carbon and 72 per cent. of oxygen; that the leaf of a plant absorbs carbon and nitrogen, while it rejects the oxygen; that 50 pounds of carbon and 50 pounds of water produce 100 pounds of woody fibre; that 50 pounds of carbcn and $72 \frac{1}{2}$ pounds of water produce $122 \frac{1}{2}$ pounds of either sugar, starch, or gum; and that 50 pounds of car'bon and 56 pounds of water make 106 pounds of vinegar.

We further know that about one-half the weight of all the crops gathered, for the nourishment of man and beast, consist of carbon-the oxygen forms a little over a third part, the hydrogen enters into their composition only to the extent of a little over 5 per cent., and the azote seldom exceeds $2 \frac{1}{2}$ or 3 per cent., with from 2 to 8 per cent. of ashes. This is shown in the following analysis of the component parts of different crops in perfect dryness :

\begin{tabular}{|c|c|c|c|c|c|}
\hline & Carbon. & Hydrogen. & Oxygen. & Azote. & Ashes. \\
\hline Hay... . . . . . . . . . & 45.8 & 5.0 & 38.7 & 1.5 & 9.0 \\
\hline Hay and straw...... & 47.4 & 5.0 & 37.8 & 2.1 & 7.7 \\
\hline Potatoes............ & 44.0 & 5.8 & 44.7 & 1.5 & 4.0 \\
\hline Wheat .............. & 46.1 . & 5.8 & 48.4 & 2.3 & 2.4 \\
\hline Wheat straw........ & 48.7 & 5.3 & $38.9 \frac{1}{2}$ & $0.3 \frac{1}{2}$ & 7.0 \\
\hline 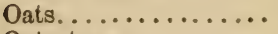 & 50.7 & 6.4 & 36.7 & 2.2 & 4.0 \\
\hline Oat straw.......... & 50.1 & 5.4 & 39.0 & 0.4 & 5.1 \\
\hline
\end{tabular}




\section{Composttion of Chemical Substances.}

The following will explain the composition of the various substances and matters mentioned in the foregoing:

$\Lambda$ mmonia consists of 14 parts of nitrogen and 3 parts of liydrogen.

Nitric acid consists of 14 parts of nitrogen to 40 parts of oxygren.

Phosphoric acid contains 31 parts of phosphorus to 40 parts of oxygen.

Superphosphate of lime contains, in 100 parts, about 60 parts of phos. phoric acid, about 25 parts of lime, and 15 parts of water.

Carbonic acid contains 6 parts of carbon and 16 parts of oxygen.

Sulphuric acid is composed of 16 parts of sulphur to 24 parts of oxygen.

Silicic acid consists, in 100 parts, of 46 66-100 of silicon to 53 34-100 of oxygen.

Carbonate of lime, in 100 parts, contains about 44 parts of carbonic acid and 56 parts of lime.

Protoxide of iron consists of 28 parts of iron to 8 parts of oxygen; and peroxide of iron, 56 parts of iron to 24 parts of oxygen.

Magnesia contains, in 100 parts, $604-100$ of magnesium to $396-100$ of oxygen.

Sulphate of lime contains, in 100 parts, 46 of sulphuric acid, 32 of lime, and about 21 of water.

Common salt contains, in 100 parts, when pure, 6068.100 of chlorine and $3932-100$ of sodium.

Nitrate of soda contains, in 100 parts, $6353-100$ of nitric acid and 36 47-100 of soda.

Potassa contains, in 100 parts, $5341-100$ of nitric acid, and $4659-100$ of potassa.

Sulphate of ammonia contains, in 100 parts, $0060-100$ of sulphuric acid, 25 76-100 of ammonia, and 13 64-100 of water. 


\section{ELEMENTS REQUIRED IN A SOIL TO PRO- DUCE GREAT FERTLLTTY.}

Every farmer is acquainted with this fact, that the bulk of all soils consists of three distinct materials, as, for instance, sand, clay and limestone soil. Fure sand is the basis of silica; pure clay is the basis of aluminum, and is composed of about 60 per cent. of silica and 40 per cent. of aluminum; and lime, or carbonate of lime, is a composition of lime and carbonic acid. But besides these three substances, the soil contains a great deal of organic and inorganic matter, and upon the quantity and quality of this latter depends the fertility or the sterility of a soil. This point is illustrated by the well-executed analysis of three different soils, given below, which was prepared by Professor Sprengel, a German chemist, while he was at the head of the Prussian High School of Agriculture. No. 1 in the analysis is a very fertile alluvial soil in Frisland, formerly covered by sea-water, but which had been cultivated over 80 years, and yielded heavy crops without any manure. No. 2 is a fertile soil near Göttingen, producing goorl crops of clover, potatoes and turnips, yielding particularly well when manured with plaster. No. 3 is a very sterile soil near Kunebourg. After sufficient water had been applied to these three varieties of land, to separate the soluble parts from the insoluble matter, the coarse sand from 
the finer ingredients, the analysis for 1,000 parts showed as follows :

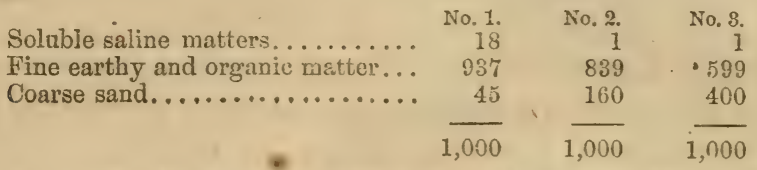

The most striking difference in these numbers is the large quantity of saline matters found in the No.1, these consisting of chloride cf sodium, chloride of potassium, sulphate of potassium, and plaster, with traces of sulphate of magnesia, sulphate of iron, and phospliate of socia. The presence of such a large quantity of saline matters is, without doubt, to be accounted for by the fact that the soil had formerly been covered by sea-water, and it was probably owing to the same circumstance that it had produced large crops without any manure. No. 3, the sterile soil, is found to be the lightest of the three -40 per cent. of it was coarse sand, but that alone is not sufficient to accomnt for its sterility, as there are soils which contain even a greater quantity of sand without being sterile. The fine matters, separateil from the coarse sand and the soluble ingredients, were, in 1,000 parts, as follows :

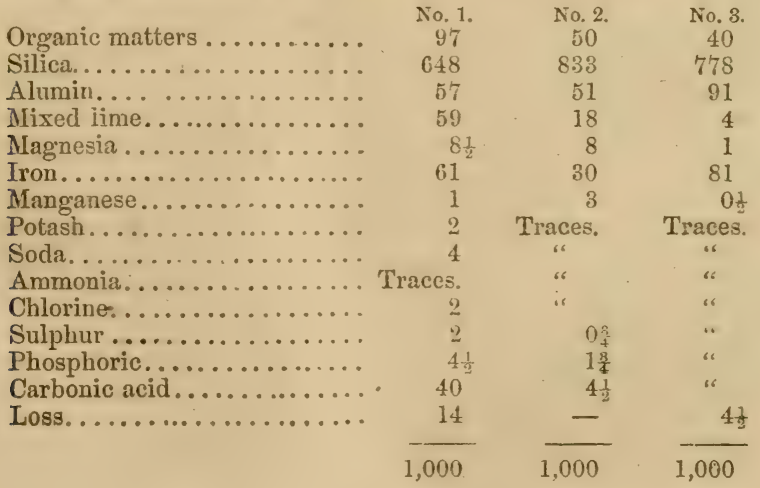


The composition of No. 1 verifies the correctness of the general principle laid down, that the presence of a great quantity of inorganic matters of every kind is needed to render a soil eminently fertile. It is necessary, not only that the soil contain a considerable quantity of soluble and saline ingredients, but that it has, in addition thereto, nearly 10 per cent. of organic matters; and this becomes of still greater importance, in consideration of the large quantity of inorganic ingredients- 6 per cent. of lime, and also potash, soda, and the different acids.

The soil No. 2, though fertile, has but a very small proportion of soluble saline matters, and amongst the insoluble parts, there exist only traces of potash, soda, and the important acids-there is only 5 per cent. of organic matters and about 2 per cent. of lime. The smallness of the quantities of some important ingredients, and the entire absence of several others, places this soil below that class of soils which would be called, naturally very fertile; but, under the treatment of a judicious farmer, it might be brought to a high degree of productiveness, while, if cultivated without manure, it would soon become unproductive.

In the "fine matters" of the soil, we find that soil No. 3 has less of the fertilizing ingredients than No. 2-the organic matters amount to about 4 per cent., and the lime to one-half per cent.; but it contains 40 per cent. of coarse sand, so that, out of 100 parts, there is only 60 per cent. of fine matters, as the first table shows. The absence to such a great degree of fertilizing ingredients would not, however, in itself be sufficient to condemn such a soil as irremediably sterile; but there is another element in the case to be considered: in the fine matters of that soil we find over 5 per cent. of oxide of iron, and experience has proved that where there is so small a quantity of the vegetable matters, that 
proportion of oxide of iron is too great, and would exercise a very hurtful influence on cultivated plants. To improve such a soil, it would be necessary not only to furnish it with additional inorganic ingredients, but also with other reactive matters, which should neutralize the injurious effects of the oxide of iron.

In the analysis of these three soils, we find that the first sample contains in itself all the elements of fertility in great plenty; the second sample presents a soil which, thongh fertile, is wanting in several important elements, but which could be supplied by manuring, and it is reported that plaster produces a particularly good effect upon it; and, finally, in the third sample, we have a soil which is not only wanting in a great variety of inorganic elements necessary to the life and growth of plants, but which also abounds in an inorganic substance that is always injurious to vegetable life.

The following is an analysis of a very fertile soil in the vicinity of the Zuyder Zee, in Holland, as given by the celebrated chemist, Mulder:

Insoluble sand with alumina.............. 57.646

Soluble silica........................ 2.340

Alumina, soluble..................... 1.830

Peroxide of iron....................... 9.039

Protoxide of iron .................... 0.350

Lime............................... 4.092

Magnesia .............................. 0.130

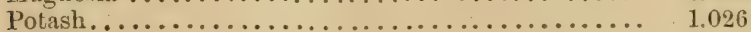

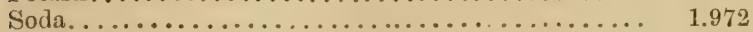

Ammonia ............................. 0.060

Phosphoric acid........................ 0.466

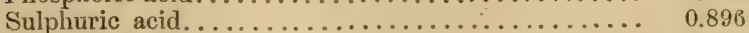

Carbonic acid............................. 6.08.5

Chlorine................................. 1.240

Humus, or mold, vegetable remains and water chemically combined...................... 12.000

Loss............................... 0.828

Total...................... 100.000 
This is a most remarkably rich soil, and few in the world can compare with it in furnishing the raw material for producing bread and meat.

These examples will help farmers to comprehend of what great service a chemical analysis may be in enlightening them as to the composition and real value of a soil, and they will readily see the practical benefits to be derived therefrom. 


\section{EFFECTS OF VARIOUS KINDS OF MANURE EXPLAINED.}

\section{MR. VILLE'S THEORIES DISCUSSED.}

In the discussion of the advantages resulting from using the various kinds of manures and fertilizers, the main object will be not to set up new theories, so much as to show, by reference to experiments and the views of writers on the subjects, what we deem to be the most correct and best established principles.

Naturally, in the consideration of such a question, the point first to be referred to is the influence of farm-yard manure on the soil.

In a translation of the opinions of $\mathrm{Mr}$. Ville (the gentleman already referred to), which has been made by M. A. A. Fesquet, and published in this country, the following passage occurs :

\section{FARM-YARD MANURE.}

"Q. How does such a manure act upon the soil?

" $A$. It acts by its nitrogenized matter, phosphate of lime, potassa, and lime, which are the indispensable agents for keeping up the fertility of soils, and obtaining all kinds of crops. substances?

"Q. Does farm-yard manure contain only these four

"A. It contains at least ten more, which it is not necessary to consider, since plants always find them in the earth and in the air." 
The writer here apparently ignores altogether the beneficial effects on the soil produced by the nitrification, the fermentation, and the dissolvent power of farm-yard manures.

In another part of the same work I find the following:

"Q. Is it known in what proportion the soil and air furnish nitrogen for the principal crops?

" $A$. Here are the proportions indicated by carefully made experiments:

\begin{tabular}{|c|c|c|}
\hline Nitrogen. & From the Air. & $\begin{array}{l}\text { From the Soil. } \\
\text { None }\end{array}$ \\
\hline $\begin{array}{l}\text { Clover. } \\
\text { Barley . }\end{array}$ & $\begin{array}{l}\text { The whole. } \\
80 \text { per cent. }\end{array}$ & $\begin{array}{l}\text { None. } \\
20 \text { per cent }\end{array}$ \\
\hline Rye... & 80 & \\
\hline Wheat & 50 & 50 \\
\hline Beets ............. & 60 & 40 \\
\hline Rape or cole seed (colze & $70 \cdots$ & 30 \\
\hline
\end{tabular}

"Q. How can we prove that it is so, and that clover or" peas, for instance, take no nitrogen from the earth, and draw it all from the air?

" $A$. It may be proved in two different ways-by laboratory experiments, and by culture in the field. Let us speak first of the laboratory experiments, because the results are simple and certain.

"A sample of earth was calcined in a porcelain furnace, in order to destroy all organized substances which may have existed in it; this earth was then mixed with phosphate of lime, potassa, and lime, and watered with pure distilled water. Clover sown in it grew perfectly well, and the crop being analyzed, de:nonstrated the presence of a large proportion of nitrogen, evidently due to the air, since there was none in the soil.

"The practical proofs are not less certain. When a soil is cultivated without manuring, the crops become poor very rapidly. When wheat is grown every other year, the crop is better; if wheat alternates with horse-beans, which con- 
tain a great deal of nitrogen, the yield of wheat does not diminish. Indeed, the rotation with horse-beans is nearly as favorable to wheat as a year of fallow land. 'Why is it so? Because horse-beans draw their nitrogen from the air, whereas wheat extracts it from the soil."

My reply to this statement is, that the sample of calcined earth, mixed as described, was in the very best condition to form nitrates, and a crop of wheat even could have been growu upon it. It cannot be stated in what proportion the nitrogen was absorbed by the soil or by the leaves.

The beneficial effert of all the long-rooted and largeleafed plants upon the soil is known perfectly well by all practical farmers, but the proofs given by Mr. Ville, are scarcely sufficient to warrant such sweeping assertions as he has made.

Concerning the calcined or burned soil, I take the opportunity of stating that, in the mountainous regions of Europe, the most unproductive soils are, from time to time, thinly over-sliced and burned in small heaps in the dry season; then the dried heaps are left for nitrification undisturbed until the seeding-time, when the heaps are evenly spread, and the seed sown, the burnings being hoed in in small rows., Low, wet, turfy lands, which can readily be drained, are, when dry, burned to the extent of six or seven inches deep, and one-half, more or less, of the burnings is used for the manuring of other soils, as it is said the whole quantity, if used, would render the soil too rich. The characteristics of the crops of these fields are: stifi straw, with well-filled ears, and a good quality of grain; they render about double the amount of grain, in proportion to the straw, of the growth of cultivated land-that is to say, one pound of straw gives as much grain as would be obtained 
from two pounds of the straw of cultivated land. This is due to the dissolvent power of burning on the inorganic matter, which is the cause of nitrification.

Mr. Ville also says that " 30 per cent. of nitrogen is lost during the decomposition of animal substances," and that this loss is altogether unpreventible and without remedy. This is not so, as the application of plaster in large quantities would have prevented the loss of nitrogen. In composing his fertilizers, he calls the sulphate of lime, limethe incredulous believe that it is more soluble; but the fatct is, that 500 parts of water will dissolve one part of plaster, while it takes 1,000 parts of water to dissolve an equal quantity of calcined lime; therefore, how can his theory be correct? It should be noted that Mr. Ville constantly speaks of plaster as lime, when it really contains only 32 parts of lime, the rest being sulphuric acid and water. Several times he says, also, that goda has no effect on plants; but, in the end, he found that, practically, it was useful for roots, and even potatoes.

In the same work, referring to potassa, we find the following:

" $Q$. Which is preferable, nitrate of potassa, or refined potassa?

"A. Nitrate of potassa is preferable, because its potassa costs 0.75 francs per kilogramme (or about seven cents per pound), whereas, that of the refined potassa amounts to 1.50 franes per kilogramme (or 14 cents per pound)."

At the very time this was written, in Germany, refined potassa, of 50 to 54 per cent. of pure potassa, was quoted from 2 to $2 \frac{1}{2}$ cents, gold, per pound. Is this not very much like intentionally ignoring known facts? 


\section{ABSORPTION OF ATMOSPHERIC NITROGEN BI VEGETATION.}

This subject has been treated upon by M. S. P. Dehérain, a well-known writer upon agricultural topics, and member of the French Academy of Science. The subjoined is an abstract of a lecture delivered by M. Dehérain, some years since, before the members of the Academy:

Numerous analyses of arable earths have been made, and form part of the records of agricultural science. We find this fact to be clearly demonstrated - that there exists in the soil a considerable quantity of combined nitrogen, the origin of which cannot be attributed to old dressings, inasmuch as M. Boussingault has discovered that the amount of nitrogen absorbed by vegetation during the growth of crops, upon a given surface, exceeded the quantity contained in the manure which that surface had received. The excess is often very considerable; and the explanation must be, either the admission that plants draw nitrogen directly from the air, and retain it in their tissues, or that, in consequence of some reaction, as yet imperfectly understood, arable earth becomes charged with atmospheric nitrogen, which is then transmitted to the vegetation.

The numerous experiments of $M$. Boussingault, in France, and Messr's. Laws, Gilbert and Pugh, in England, attempted with a view of ascertaining if plants absorb nitrogen direct from the air, have failed. The ammonia, or 
nitric acid, which may be prorluced by meteoric phenomena, rain, snow, or dew, is scarcely sufficient to cover the loss occasioned by the evaporation of ammonia in the air, by the draining of superficial and subsoil (which would easily be the means of carrying away nitrates), and by the emission of free nitrogen, which is produced during the decomposition of organic matter used as manure. It is, therefore, evident, a priori, that some powerful canse must act npon the soil to produce that fraction of nitrogen, the presence of which is proved by analysis. After reflecting upon the various circumstances under which the union of the two elements of the air occurs, it is found to habitually accompany the oxidation of the organic matter, and it seemed to me, that oxidation of the organic matter arising from the remains of former vegetation, or from manure, might, perhaps, produce the combination of atmospheric nitrogen with oxygen.

To render this certain, I resolved to undertake two series of experiments. By the first, I have ascertained the absorption of gaseous nitrogen during the oxidation of organic matter. In the second experiment, I examined the nitrogen in combination, with the view of discovering and pointing out those reactions which produce the black matter (or humus) of arable earth. After several attempts, I succeeded in obtaining a regular absorption of nitrogen by the following means: Into a matrass of green glass, capable of containing 200 cubic centimetres, was introduced a mixture of equal volumes of air and oxygen, whose esact compositions had been ascertained, and then a liquid, consisting of 15 grms. of glucose, dissolved in 15 c. c. of water, and 15 c. c. of common ammonia. This is closed before the blowpipe, and if the manipulation is rapid, only a very insignificant portion of air can enter the matrass. Even 
should a larger quantity obtain entrance, the experiment will not be spoiled. The proportion of nitrogen in the matrass will become rather larger than is indicated by the analysis, only a small quantity of the nitrogen absorbed passing unperceived. Heat is applied for 100 hours by the water bath, and when completely cooled, the height of the liquid is marked upon the neck of the reversed matrass, and the end is broken under water. Compared with the preceding proportions, the absorption is considerable, nothing but nitrogen remaining; all the oxygen and carbonic acid will have disappeared. The gas is collected in a graduated eprovette (or tester); the entire absence of oxygen, or carbonic acid, is ascertained by the application of potash and pyrogallic acid; and the remaining quantity of nitrogen is read off, the quantity being considerably less than what was introduced. Here are particulars of the two experiments:

Of 100 parts of gas introduced, $58 \frac{40}{100}$ consisted of oxygen, $41 \frac{60}{100}$ of nitrogen; the liquid glucose and ammonia occupied 30 c. c., and the gas contained in matrass 184 c. c. Before the experiment, there were $76_{\frac{5}{10} \sigma}$ c. c. of nitrogen in the mixture; when, after heating the matrass, the end was broken under water, only 70 c. c. of gas were found, containing neither oxygen nor carbonic acid- $6 \frac{5}{100}$ c. c. of nitrogen were, therefore, absorbed, or $8 \frac{6}{100}$ per cent.

In one of the experiments, made with the nitrated glucose of H.P. Thenard, and with ammonia, with gas containing 52 of nitrogen to 48 of oxygen, an absorption was ascertained of 113 c. c., against 53 introduced; that is to say, 215 per cent. Six experinents were made with humic acid mixed with potash, acting upon atmospheric air; and of 100 volumes of nitrogen introduced, an average of seven volumes was absorbed. Two experiments were made with 
decayed wood mixed with potash; the introduced gas was rich in oxygen- 36 volumes were absorbed per cent. . Upon substituting ammonia for the potash, no absorption of nitrogen was perceived; on the contrary, at the end of the experiment, more nitrogen was found than at the commencement. In twenty of these experiments, made with glucose and ammonia acting upon equal volumes of air and oxygen, an average absorption was established of $5_{100} \frac{9}{100}$ c. c. of nitrogen to 100 introduced. Lastly, in four experiments, in which a mixture of M. P. Thenard's nitrated gilucose with ammonia was employed, an average absorption of 15.4 to 100 of introduced nitrogen was observed.

Thus, in the presence of slow combustion of organic matters, atmospheric nitrogen enters into combination, probably to form nitric acid, which, from contact with excess of carbonaceous matter, is reduced, and yiclds its nitrogen to the organic matter. This last reaction has been established by M. P. Thenard, and having verified it, we may, by depending upon it, endeavor to imagine what is the origin of the excess of nitrogen found in plants, and in thie soil, over the quantity furnished by manures. The conditions under which atmospheric nitrogen is brought into combination, require that some organic matters should be consumed in the air; every plant, whose leaves remain upon the soil which bears it, is the means of more or less fixation of nitrogen. This reaction continues during inany years, and ends by accumulating, upon soil abandoned to spontaneous vegetation, such as waste land, a quantity of nitrogen sufficient to enable a cultivator, after clearing, to obtain several crops without the action of nitrated manure.

The productive powers of the soil of forests and prairies are, however, not to be compared to those of arable land. The vegetable remains left upon the former are not in so 
favorable a state for fermentation as those which form the dressing received by the latter; f'or we have already seen that nitrated glucose, which occurs during the manufacture of farm-yard manure, is the most favorable of all mixtures employed for the fixation of atmospheric nitrogen. The action of manure upon vegetation is lot due only to the nitrogen it holds, but also to the decomposing carbonaceous matter which constitutes the entire mass. When buried in the earth, this matter is preserved there some time, if the cultivator does not endeavor to finish its oxidation. To this end, he tears the earth, he aërates it, he is unsparing of his means; under the influence of the air, the organic matter burns, producing in the soil those considerable quantities of carbonic acid which the analyses of Messrs. Boussingault and Levy have discovered in the air. This combination determines the union of the two elements of the air, and there is added to the nitrogen, which the dressing naturally contains, that which, drawn from the atmosphere, is thence conducted through a series of metamorphoses, from the soil to the plant, and from the plant to animals.

What are the conditions of composition, aëration, and moisture most favorable to the fixation of atmospheric nitrogen in arable soils? This is an important question, since, by experiments, the circumstances under which the combination of gase us nitrogen occurs are very clearly defined; and it is also known that it does not so easily take place if the oxidation is either too rapid or too slow.

The French Association at Paris for the Encouragement of Science has recognized the importance of making further inquiries upon this subject by offering a prize of 2,000 francs for the best mode of procuring the absorption of atmospheric nitrogen, either in the form of nitrates, ammonia, or cyanogen. The prize is offered for the year 1876 . 
Nitrate of potassa is obtained by the decomposition, under large open sheds, of materials of animal origin.mixed with earths holding clay and limestone, and which are afterwards lixiviated, in order to extract the nitre. This salt, for a long time, was produced from old building materials. It is not generally known amongst agriculturists that, by such a very simple process, nitrogen can be obtained.

\section{THE PASSAGE OF GASES THROUGII THE VEG ETABLE COLIOIDAL MEVBRANE.}

The recent experiments of M. Bartholomy lead to the conclusion that the natural colloidal surfaces of vegetables have 13 to 15 times greater admissive power for carbonic acid than for nitrogen, and six to seven times more than for oxygen. These experiments, proving the dialysis of carbonic acid through the cuticle of leaves, are of the same nature as the investigations of Dutrochet, on membranes and aqueons solutions, made with a view to determine the endosmose by the cellules. In a word, cuticular respiration appears sufficiently proved by the presence of this membrane on all the organs. 


\section{RESULTS OF AN INVESTIGATION IN EAST INDIA.}

Some additional information may be gathered on this subject by a perusal of the following extract from a very valuable and carefully prepared report made to the British Government by Mrr. Edward Nicholls, a gentleman who was appointed specially for the purpose of making an investigation as to the quality and composition of water for drinking purposes in Eastern India:

\section{Nitrates.}

Nitrates are invariably found in well-water derived from subsoils of decomposed felspar or of clay. Ammonia, whether that normally found in the atmosphere or that produced by organic decay, becomes oxidized when in contact with porous soil ; and in presence of bases with weak acids, such as silicates and carbonates, it changes into nitric acid, and expels the weaker acid. As there are few soils that do not contain silicates or carbonates of potassium, sodium, magnesium, or calcium, the presence of nitrates is nearly universal, and we would naturally expect to find them in the washings of salt mounds. The filtration of water through soil containing silicates or carbonates would generate nitrates, even if none were present originally. I found as much as 15 per cent. of nitric acid in the solid residue of a sample of earth washings-a quantity equal to 76 centi- 
grammes per litre of the fluid, and the moisture adhering to the crystals of salt, subsequently olstained, was highly nitrous. The nitrates present in earth washings are always deliquescent nitrates of calcium and magnesium, the sodium salts being excluded, in consequence of earthy sulphates and chlorides having already decomposed any sodium silicate or carbonate that would have been available for the saturation of nitrie acid, as it is formed.

Potassium, being of comparatively rare occurrence in these soils, is excluded also from combination as nitrate. Nitrates, existing in every sample of earth washings that I have examined, are consequently wasted; while, if the mother liquor of the salt crystals was treated with wood ashes, or other convenient source of potash, the earthy metals would be replaced by potassium, and nitrates would be obtained; the quantity obtained, it is true, would be not more than two or three per cent.

The nearest place where I could ind nitrates to be regularly made was at Sirragirri, about 20 miles north of Bellarg. From the account given me of the process by the nitrate maker of Sirragirri, it would appear that earthy nitrates are never utilized, and that soil containing potassium nitrate already formed, is the only kind worked. To obtain nitrates at once in this condition, in a country where potassium salts are in the soil, the nitrate maker must contine his operations to soils in the neighborhood of villages, selecting those spots where, from infiltration of urine, from drainage of cattle-sheds, or from the vicinity of ash-heaps, the earth has become artificially supplied with potash. Considering that Indians generally use the manufacturing processes which are best adapted to circumstances, and which, thongh rude, prove quite as profitable to them as the more ingenions, but more expensive, processes of Euro- 
pean industry, I am rather surprised that the addition of potash to earth washing's containing earthy nitrates is not practiced in India as in Europe. The earth washings are allowed to evaporate, and are lost in the mother liquor. The nitrate is obtained, tolerably clear, in small prismatic crystals, mixed with the cubic crystals of common salt; this impurity varies from sir to twenty per cent., or more; if required to be refined, it is purified by solution and recrystalization-a most wasteful process, under the circumstances, as about 30 per cent. of the nitrate is lost.

The impure nitrate is sold at one rupee per mound of 24 lbs.; when purified, the same quantity costs one rupee twelve annas; this low figure is, I think, occasioned by the nitrate being impure for shipment, as the manufacturers are not acquainted with the process of refining economically. The nitrate might be bought and refined at a total cost of not more than 12s. per ewt., it being worth $28 s$. to 30 s. at home. Ignorance of an economical refining process affords the only explanation of the low prices obtained for an article of such value. To refine it economically, it would be necessary to accumulate a large quantity, mix it well, and determine by analysis of a sample the process to be adopted for its purification. The process applicable to a nitrate containing five per cent. of impurity, would be quite inapplicable to another containing 40 per cent. of impurity.

\section{SODA.}

I have not been able to meet with any instance of this salt being produced near Bellarg; that sold in the ceded districts is made, I believe, near Cuddolph; the sodinm carbonate, of which impure soda principally consists, is the result of decomposition of sodium silicate by atmospheric carbonic acid. Silicate and carbonic acid are of equal strength, and 
it entirely depends on circumstances which acid can expel the other from the combination. Silicic acid expels carbonic acid from solution, whilst carbonic acid acting in excess, and for long periods of time, expels silicic acid from silicates. In parts where soda is produced, it is found principally as an efflorescence on the surface, the sodium silicate of the soil having evidently been decomposed by atmospheric acid. Its presence is incompatible with that of earthy chlorides, sulphates and nitrates, and as these are constantly found accompanying the salt and nitrates yielded by black cotton soil, it is evident that the production of salt or nitrates excludes that of soda. Natural sodium carbonate does not appear to be produced in India to any considerable extent -perhaps little in excess of the limited requirements of washermen. The main features of the production of these earth salts may be thus summarized:

Salt is derived from marine deposits in the black cotton soil ; it may be mixed with the following impurities:

(1.) Marine earthy salts, principally magnesium chloride and sulphate.

(2.) Sodium sulphate, produced by decomposition of marine sulphates by sodium silicate.

(3.) Nitrates, principally magnesium and calcium.

Nitrates do not accompany salt as such (as potash nitre), but indirectly as earthy nitrates. Potash can only be obtained from soils to which potassium has been added accidentally or purposely; soils containing the nitrified products of decayed animal matter are alone profitable to work ; even in these there is a great loss, unless potassium salts be added. Soda is produced by action of carbonic acid on the sodium silicate of decomposed felspar rocks; both carbonate and the silicate of sodium being decomposed by the soluble earthy salts which invariably aceompany salt; and nitre soils yielding the latter salis cannt yield soda. 


\section{RESEARCHES OF BOUSSINGAULT ON THE NITRIFICATION OF THE SOIL.}

M. Boussingault, in the reports presented by hin to the Academy of Science, at Paris, France, gives the results of experiments made in hermetically sealed glass balloons, during a period of eleven years, with specially prepared soils and common air. These experiments proved that no more nitrates were produced during that eleven years than were formed during the first sixteen or eighteen months; in all cases it was found that not one-fourth of the nitrogenabsorbing capacity of the soil was saturated, and the quantity of nitrogen in the inclosed air did not change, although nitrification took place. Therefore, we infer that confined dry air with a dry soil will not offer the best conditions for promoting nitrification, as is proved in another part of this work.

One of M. Boussingault's experiments was on ten kilogrammes (equal to 22 pounds) of air-dried garden soil, which was first washed, to deprive it of the most of its nitrates, and then exposed to the aị under cover, being every two weeks moistened. The indications of the presence of nitrates was as follows:

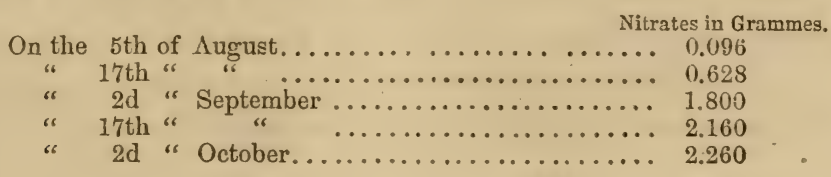


After the last-mentioned date, the nitrification was continued but very feebly; and several other trials made in the same way showed but little variation in the quantity of nitrates present.

\section{Percentages of Saltpetre in Soil.}

M. Boussingault also shows the percentages of saltpetre contained in some of the soils in France, which had been worked for a number of years in the manufacture of powder, to be as follows:

Quantity of Saltpetre in each Kilogramme of Earth.

In the Northern Provinces. . ................... 1.2 No. of Grammes.

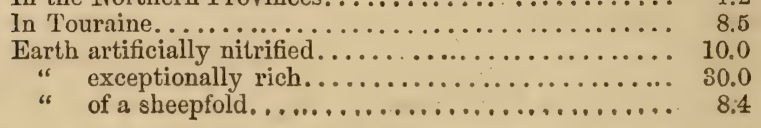

The artificial nitre beds consisted of clay soil, mixed with lime and animal matters, under an open shade, and worked over as a compost heap, generally for a period of 15 to 18 months.

In the same address, which was delivered about a year ago, M. Boussingault repeated a statement which he said he had made before the Academy many years previous, - that land well plowed and manured possessed very much or the same qualities as a nitre bed-in both cases the minerals are associated with inorganic matters in forming the composition.

Among the nitre mines on the equatorial line, the most important is that known as the Tacunga, which is very rich: it is composed of humus, phosphates, silicate of lime, and a great proportion of alkalies. In many parts of Spain the soil is so rich that the farmer can produce either saltpetre in great abundance or very large crops of wheat. In the 
valley of the Ganges, in India, the saltpetre of Houssage is very much renowned; it is found in great quantities on the surface of the soil, where it is deposited by the waters of the river, and it is found side by side with rich crops of tobacco, indigo, maize, \&c. Therefore, it is certain that the association of mineral elements with organic matters is not the only condition upon which depends the formation of nitrates. There is in Peru an inexhaustible deposit of the nitrate of soda which, for its great abundance, is compared to the deposit of the common salt, except that it has a different origin.

\section{The Nitre Beds of Algeria}

Have been described somewhat minutely by Colonel Chabrier, an officer of the French army, who, when serving in Algiers, embraced the opportunity of studying them very carefully. They are found on the sites of destroyed villages, and are composed of organic and animal matter mixed with mineral ingredients, such as lime, phosphate, silicates, and alkali salts, in a more or less decomposed state. The richness and consequently the value of these nitre beds depended upon the quantity of organic and mineral matters found in them, those containing the greatest proportion and in the most advanced state of decomposition being the highest in point of value. 


\section{JEAUNEL ON NITRATES AND NITRITES.}

The following is an extract from a paper by M. J. Jeaunel, a member of the French Academy:

"Many physiologists and horticulturists believe that it is impossible to group plants in a sterile soil by means of artificial food composed of mineral substances dissolved in water. My aim is to prove by experiments, (1) that nitrates and nitrites are naturally found in soils containing organic vegetable matter when in contact with air; (2) that it is possible to feed plants with solutions of mineral compounds suitably prepared, so that the plants receive from these solutions the mineral constituents they require, and may thus grow more vigorously even in pure sand than in the best garden mold.

"This opinion was put forth in 1856 by Boussingault, as the result of his experiments, and now the same conclusion is arrived at by My. Ville.

"Soils containing humus or lime determine, while dry* ing, the combination of the elements of the air, without any intervention of ammonia, so that either nitric or nitrous acid is formed, which is at once fixed by the lime."

When a moist nitrogenized animal matter is exposed to the action of the air, ammonis is always liberated; nitric acid is never formed. But when alkalies or alkaline bases are present, a union of oxygen with the nitrogen and nitrates is formed.-Liebig. 


\section{ANALYTICAL TABLES.}

COMPILED BY Dr. EMILE WOLF.

The following analyses are selected from a series published in a very celebrated analytical work by Dr. Emile Wolf, Superintendent of Experimental Department at the Royal Agricultural Academy at Hohenheime, Wurtemburg, Germany.

Table I shows clearly the dominating influence of the four principal ingredients-potash, lime, and phosphor, with nitrogen-over the secondary mineral salts in the principal agricultural crops. In the crops described as maximum, where the four dominating ingredients are found in the largest quantities, the secondary ingredients are also present to a great extent; while, in the minimum crops, where the four dominating ingredients are in the smallest quantity, their influence on the secondary ingredients is nearly lost, because the latter can scarcely be found present in the crops.

Table II shows the influence upon the ashes in plants of the alkali salts-potash and soda-when present in either a maximum, mean, or minimum quantity. The study of this table will be of great interest, as the presence of a larger or smaller quantity of the alkalies is seen to have a strikingly different effect upon the other ingredients. This contradicts altogether the statements of $\mathrm{Mr}$. Ville and others, that soda has no influence upon vegetable growth. The alkalies also play a very important part in the nitrification of soils.

The tables are of great importance to the practical agriculturist-they are the best upon this subject that have ever been prepared, and deserve the most careful study and perusal. 


\title{
COMPARATIVE STATEMENT OF THE PERCENTAGE OF ASHES
}

\author{
FOUND IN AN ANALTSIS OF
}

THE PRINCIPAL AGRICULTURAL CROPS.

\begin{tabular}{|c|c|c|c|c|c|c|c|c|c|c|c|c|}
\hline \multirow{2}{*}{\multicolumn{2}{|c|}{ DESCRIPTION.A }} & \multirow{2}{*}{ 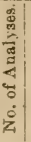 } & \multirow[b]{2}{*}{ 离 } & \multicolumn{9}{|c|}{ IN 100 PARTS OF PURE ASHES. } \\
\hline & & & & : & :ुํ. & 离 & 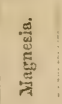 & 密 & 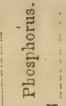 & 岂 & $\stackrel{\Xi}{\ddot{~}}$ & 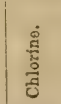 \\
\hline w Hay.......... & & 39 & $\mid \begin{array}{r}11.30 \\
6.02 \\
2.20\end{array}$ & $\begin{array}{r}56.58 \\
25.54 \\
7.63\end{array}$ & $\begin{array}{r}13.78 \\
4.43 \\
0.30\end{array}$ & \begin{tabular}{|r|}
32.70 \\
16.72 \\
8.38
\end{tabular} & $\begin{array}{r}16.65 \\
6.31 \\
2.52\end{array}$ & $\begin{array}{l}4.92 \\
1.25 \\
0.13\end{array}$ & $\begin{array}{r}21.31 \\
8.01 \\
4.61\end{array}$ & $\begin{array}{l}8.64 \\
4.56 \\
0.65\end{array}$ & $\begin{array}{l}63.21 \\
27.01 \\
10.44\end{array}$ & $\begin{array}{r}21.39 \\
7.22 \\
1.88\end{array}$ \\
\hline Red Clover in Flower.. . & & 98 & $\begin{array}{l}9.15 \\
6.83 \\
5.02\end{array}$ & $\begin{array}{r}52 \\
32.15 \\
8.77\end{array}$ & $\begin{array}{l}8.89 \\
2.03 \\
0.00\end{array}$ & $\begin{array}{l}53.36 \\
35.22 \\
21.91\end{array}$ & $\begin{array}{r}26.07 \\
10.89 \\
\mathbf{5} .34\end{array}$ & $\begin{array}{l}5.01 \\
1.06 \\
0.32\end{array}$ & $\begin{array}{r}15.00 \\
987 \\
4.01\end{array}$ & $\begin{array}{l}665 \\
3.01 \\
1.26\end{array}$ & $\begin{array}{r}20.20 \\
2.37 \\
0.00\end{array}$ & $\begin{array}{l}11.76 \\
3.89 \\
1.20\end{array}$ \\
\hline ucerne............. & & 9 & $\begin{array}{l}9.53 \\
7.46 \\
5.36\end{array}$ & $\begin{array}{l}41.91 \\
24.58 \\
11.40\end{array}$ & $\begin{array}{l}6.22 \\
2.05 \\
0.40\end{array}$ & $\begin{array}{l}62.88 \\
42.17 \\
24.74\end{array}$ & $\begin{array}{l}9.00 \\
5.24 \\
2.80\end{array}$ & $\begin{array}{l}3.01 \\
1.38 \\
0.50\end{array}$ & $\begin{array}{r}19.34 \\
8.80 \\
4.54\end{array}$ & $\begin{array}{l}8.58 \\
5.93 \\
3.94\end{array}$ & $\begin{array}{r}19.85 \\
6.07 \\
0.81\end{array}$ & $\begin{array}{l}8.05 \\
3.45 \\
0.95\end{array}$ \\
\hline Winter Wheat (grain).. & & 98 & $\begin{array}{l}2.46 \\
1.97 \\
1.58\end{array}$ & $\begin{array}{l}36.60 \\
31.16 \\
23.18\end{array}$ & $\begin{array}{l}9.07 \\
2.25 \\
0.00\end{array}$ & $\begin{array}{l}8.21 \\
3.34 \\
0.90\end{array}$ & $\begin{array}{r}16.26 \\
11.97 \\
9.10\end{array}$ & $\begin{array}{l}2.99 \\
1.31 \\
0.00\end{array}$ & $\begin{array}{l}52.62 \\
46.98 \\
39.20\end{array}$ & $\begin{array}{l}2.22 \\
0.37 \\
0.00\end{array}$ & $\begin{array}{l}5.91 \\
2.11 \\
0.00\end{array}$ & $\begin{array}{l}1.01 \\
0.22 \\
0.00\end{array}$ \\
\hline ummer Whea & & 14 & $\begin{array}{l}2.23 \\
2.14 \\
2.07\end{array}$ & & $\begin{array}{l}4.06 \\
1.93 \\
0.2 \mathrm{i}\end{array}$ & $\begin{array}{l}4.12 \\
2.93 \\
2.07\end{array}$ & $\begin{array}{l}13.62 \\
12.09 \\
10.68\end{array}$ & $\begin{array}{l}0.59 \\
0.51 \\
0.30\end{array}$ & & $\begin{array}{l}2.48 \\
1.52 \\
0.20\end{array}$ & $\begin{array}{l}2.14 \\
1.64 \\
0.23\end{array}$ & $\begin{array}{l}0.80 \\
0.48 \\
0.07\end{array}$ \\
\hline Vinter Rye (grain).... & & 20 & $\begin{array}{l}3.52 \\
2.09 \\
1.60\end{array}$ & $\begin{array}{l}37.54 \\
31.47 \\
27.78\end{array}$ & $\begin{array}{l}4.45 \\
1.70 \\
0.00\end{array}$ & $\begin{array}{l}4.11 \\
2.63 \\
1.34\end{array}$ & $\begin{array}{l}14.37 \\
11.54 \\
10.13\end{array}$ & $\begin{array}{l}3.88 \\
1.63 \\
0.20\end{array}$ & & $\begin{array}{l}3.02 \\
1.10 \\
0.00\end{array}$ & $\begin{array}{l}4.51 \\
1.88 \\
0.52\end{array}$ & $\begin{array}{l}1.50 \\
0.61 \\
0.00\end{array}$ \\
\hline 3arley (grain) & & 50 & $\begin{array}{l}3.09 \\
2.60 \\
1.90\end{array}$ & & $\begin{array}{r}6.00 \\
2.53 \\
0.00\end{array}$ & $\begin{array}{l}4.20 \\
2.60 \\
1.21\end{array}$ & $\begin{array}{r}12.47 \\
8.6 \\
5.00\end{array}$ & $\begin{array}{l}2.93 \\
0.97 \\
0.00\end{array}$ & & $\begin{array}{l}3.50 \\
1.69 \\
0.00\end{array}$ & $\begin{array}{l}36.73 \\
27.54 \\
17.27\end{array}$ & $\begin{array}{l}5.24 \\
0.93 \\
000\end{array}$ \\
\hline Dats (grain).. & & 23 & $\begin{array}{l}4.07 \\
3.14 \\
2.50\end{array}$ & $\begin{array}{l}24.30 \\
16.35 \\
12.94\end{array}$ & $\begin{array}{l}5.27 \\
2.24 \\
0.00\end{array}$ & $\begin{array}{l}8.35 \\
3.73 \\
1.31\end{array}$ & $\begin{array}{l}9.72 \\
7.06 \\
4.93\end{array}$ & $\begin{array}{l}2.05 \\
0.67 \\
0.00\end{array}$ & & $\begin{array}{r}4.01 \\
1.36 \\
0.00\end{array}$ & $\begin{array}{l}55.95 \\
44.33 \\
38.46\end{array}$ & $\begin{array}{l}2.38 \\
0.58 \\
0.00\end{array}$ \\
\hline Indian Corn (gra & $\begin{array}{l}\max \\
\text { medi } \\
\text { mi:t }\end{array}$ & 9 & $\begin{array}{l}1.72 \\
1.51 \\
1.28\end{array}$ & $\begin{array}{l}31.86 \\
27.93 \\
24.33\end{array}$ & $\begin{array}{l}7.54 \\
1.83 \\
0.00\end{array}$ & $\begin{array}{l}3.76 \\
2.28 \\
0.27\end{array}$ & & & & $\begin{array}{l}4.13 \\
1.30 \\
0.00\end{array}$ & $\begin{array}{l}5.54 \\
1.88 \\
0.00\end{array}$ & $\begin{array}{l}4.79 \\
1.42 \\
0.00\end{array}$ \\
\hline Peas (grain)..... & $\begin{array}{l}\text { max. } \\
\text { medt. } \\
\text { min. }\end{array}$ & 29 & $\begin{array}{l}4.27 \\
2.73 \\
2.36\end{array}$ & & $\begin{array}{l}3.57 \\
0.96 \\
0.00\end{array}$ & $\begin{array}{l}7.90 \\
4.99 \\
2.21\end{array}$ & $\begin{array}{r}13.02 \\
7.96 \\
5.80\end{array}$ & & & $\begin{array}{l}9.46 \\
8.49 \\
0.00\end{array}$ & $\begin{array}{l}3.02 \\
0.86 \\
0.00\end{array}$ & $\begin{array}{l}6.50 \\
1.54 \\
0.00\end{array}$ \\
\hline Horse Beans (grain). & $\begin{array}{l}\max \\
\text { med. } \\
\text { min. }\end{array}$ & 15 & $\begin{array}{l}4.30 \\
3.57 \\
3.28\end{array}$ & & $\begin{array}{l}2.61 \\
1.34 \\
0.00\end{array}$ & $\begin{array}{l}8.90 \\
4.73 \\
2.86\end{array}$ & $\begin{array}{r}9.86 \\
7.08 \\
5.33\end{array}$ & $\begin{array}{l}1.06 \\
0.57 \\
0.00\end{array}$ & & $\begin{array}{l}4.63 \\
2.53 \\
1.37\end{array}$ & $\begin{array}{l}5.24 \\
0.73 \\
0.00\end{array}$ & $\begin{array}{l}6.85 \\
1.57 \\
0.00\end{array}$ \\
\hline Beans (grain). . & $\begin{array}{l}\max . \\
\text { med. } \\
\text { min. }\end{array}$ & 13 & $\begin{array}{l}4.02 \\
3.22 \\
2.85\end{array}$ & $\begin{array}{l}51.90 \\
44.01 \\
37.30\end{array}$ & $\begin{array}{l}4.20 \\
1.49 \\
0.00\end{array}$ & $\begin{array}{r}13.40 \\
6.38 \\
1.20\end{array}$ & $\begin{array}{r}12.12 \\
7.62 \\
5.80\end{array}$ & $\begin{array}{l}0.70 \\
0.32 \\
0.00\end{array}$ & $\begin{array}{l}46.60 \\
35.52 \\
27.10\end{array}$ & $\begin{array}{l}6.40 \\
4.05 \\
1.38\end{array}$ & $\begin{array}{l}1.71 \\
0.57 \\
0.00\end{array}$ & $\begin{array}{l}2.30 \\
0.86 \\
0.00\end{array}$ \\
\hline Rapeseed (grai & $\begin{array}{l}\text { med. } \\
\text { min. }\end{array}$ & 18 & $\begin{array}{l}5 . \\
4 . \\
3 .\end{array}$ & & $\begin{array}{l}8.23 \\
1.63 \\
0.00\end{array}$ & $\begin{array}{l}17.30 \\
14.18 \\
10.40\end{array}$ & $\begin{array}{r}15.55 \\
11.80 \\
6.57\end{array}$ & $\begin{array}{l}3.32 \\
1.56 \\
0.63\end{array}$ & & $\begin{array}{l}9.41 \\
2.39 \\
0.00\end{array}$ & \begin{tabular}{|l|}
5.99 \\
1.42 \\
0.00
\end{tabular} & $\begin{array}{l}0.88 \\
0.16 \\
0.00\end{array}$ \\
\hline
\end{tabular}


COMPARATIVE STATEMENT, dc-Continued

\begin{tabular}{|c|c|c|c|c|c|c|c|c|c|c|c|c|}
\hline \multirow{2}{*}{\multicolumn{2}{|c|}{ DESCRIPTION. }} & \multirow[b]{2}{*}{ 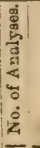 } & \multicolumn{10}{|c|}{ IN 100 PARTS OF PURE ASHES. } \\
\hline & & & 宽 & 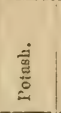 & वृँ & 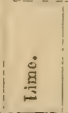 & 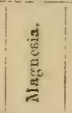 & ¿્વ & 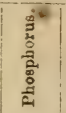 & 咅 & 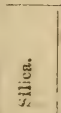 & t) \\
\hline Flaxseed (grain)... & $\begin{array}{l}\max \\
\text { med } \\
\text { min }\end{array}$ & 5 & $\begin{array}{l}4.19 \\
3.69 \\
3.05\end{array}$ & $\begin{array}{l}85.97 \\
30.68 \\
27.14\end{array}$ & $\begin{array}{l}3.24 \\
2.07 \\
1.27\end{array}$ & $\begin{array}{l}945 \\
8.10 \\
6.60\end{array}$ & $\begin{array}{l}1807 \\
14.29 \\
10.04\end{array}$ & $\begin{array}{l}2.08 \\
1.12 \\
0.38\end{array}$ & $\begin{array}{l}44.73 \\
41.50 \\
35.99\end{array}$ & $\begin{array}{l}8.15 \\
2.34 \\
0.24\end{array}$ & $\begin{array}{l}2.48 \\
1.24 \\
0.40\end{array}$ & $\begin{array}{l}0.44 \\
0.16 \\
0.06\end{array}$ \\
\hline Winter Wheat (straw).. & $\begin{array}{l}\max \\
\text { med. } \\
\text { min }\end{array}$ & 18 & $\begin{array}{l}7.00 \\
5.37 \\
4.46\end{array}$ & $\begin{array}{rr}27 & 35 \\
18.65 \\
9.47\end{array}$ & $\begin{array}{l}7.23 \\
1.38 \\
0.00\end{array}$ & $\begin{array}{l}8.86 \\
5.76 \\
2.65\end{array}$ & $\begin{array}{l}5.18 \\
2.48 \\
1.25\end{array}$ & $\begin{array}{l}1.22 \\
0.61 \\
0.06\end{array}$ & $\begin{array}{l}8.90 \\
4.81 \\
2.21\end{array}$ & $\begin{array}{l}5.59 \\
2.45 \\
0.74\end{array}$ & $\begin{array}{l}72.46 \\
67.30 \\
49.58\end{array}$ & $\begin{array}{l}7.43 \\
1.68 \\
0.00\end{array}$ \\
\hline Summer Wheat (straw). & $\begin{array}{l}\max \\
\text { med, } \\
\text { min }\end{array}$ & 7 & $\begin{array}{l}6.09 \\
4.45 \\
2.99\end{array}$ & $\begin{array}{l}48.40 \\
28.91 \\
10.05\end{array}$ & $\begin{array}{l}6.57 \\
2.69 \\
034\end{array}$ & $\begin{array}{r}1461 \\
6.89 \\
2.89\end{array}$ & $\begin{array}{l}4.04 \\
2.45 \\
1.59\end{array}$ & $\begin{array}{l}1.95 \\
0.72 \\
0.17\end{array}$ & $\begin{array}{l}6.40 \\
5.15 \\
3.40\end{array}$ & $\begin{array}{l}3.95 \\
3.13 \\
1.46\end{array}$ & $\begin{array}{l}60.62 \\
47.60 \\
39.02\end{array}$ & $\begin{array}{r}6.13 \\
2.19 \\
1.10\end{array}$ \\
\hline Winter Rye (straw).... & $\begin{array}{l}\max \\
\text { med. } \\
\text { min }\end{array}$ & 10 & $\begin{array}{l}5.86 \\
4.79 \\
3.15\end{array}$ & $\begin{array}{r}26.48 \\
19.24 \\
9.83\end{array}$ & $=\begin{array}{l}6.27 \\
215 \\
0.30\end{array}$ & $\begin{array}{r}10.11 \\
8.58 \\
5.45\end{array}$ & $\mid \begin{array}{l}3.41 \\
2.72 \\
201\end{array}$ & $\begin{array}{l}2.50 \\
1.04 \\
0.16\end{array}$ & $\begin{array}{l}7.78 \\
5.14 \\
3.21\end{array}$ & $\begin{array}{l}5.79 \\
271 \\
0.83\end{array}$ & $\begin{array}{l}65.17 \\
5638 \\
46.52\end{array}$ & $\begin{array}{l}4.66 \\
2.51 \\
0.47\end{array}$ \\
\hline Barley (straw)... & $\begin{array}{l}\max \\
\text { med. } \\
\text { min }\end{array}$ & & $\begin{array}{l}6.80 \\
4.80 \\
2.97\end{array}$ & $\begin{array}{l}44.46 \\
22.85 \\
10.76\end{array}$ & $\mid \begin{array}{l}8.45 \\
4.13 \\
1.13\end{array}$ & $\begin{array}{l}13.10 \\
7.77 \\
5.84\end{array}$ & $\begin{array}{l}5.70 \\
2.60 \\
1.64\end{array}$ & $\begin{array}{l}1.98 \\
0.69 \\
0.00\end{array}$ & $\begin{array}{r}7.20 \\
4.48 \\
2.20\end{array}$ & $\begin{array}{l}8.01 \\
3 \\
0.81 \\
0.8\end{array}$ & $\begin{array}{ll}68.50 \\
52.02 \\
32 & 11\end{array}$ & $\begin{array}{l}9.05 \\
2.26 \\
0.00\end{array}$ \\
\hline Oats (straw).... & $\begin{array}{l}\max \\
\text { med. } \\
\text { mia. }\end{array}$ & 9 & $\begin{array}{l}5.20 \\
4.70 \\
8.33\end{array}$ & $\begin{array}{l}31.40 \\
22.12 \\
13.82\end{array}$ & $\begin{array}{l}4.66 \\
2.89 \\
0.83\end{array}$ & $\begin{array}{l}15.28 \\
8.86 \\
4.88\end{array}$ & $\begin{array}{l}7.03 \\
4.14 \\
2.88\end{array}$ & $\begin{array}{l}2 . \pi 0 \\
1.45 \\
0.40\end{array}$ & $\begin{array}{l}7.54 \\
4.69 \\
1.94\end{array}$ & $\begin{array}{l}\text { 4. } 36 \\
8.19 \\
2.15\end{array}$ & $\begin{array}{l}55.41 \\
4.3 .57 \\
33.03\end{array}$ & $\begin{array}{r}11.99 \\
6.81 \\
1.50\end{array}$ \\
\hline Peas (straw)...... & $\begin{array}{l}\max \\
\text { med. } \\
\text { min }\end{array}$ & 23 & $\begin{array}{l}6.80 \\
5.18 \\
3.39\end{array}$ & $\begin{array}{r}35.85 \\
22.90 \\
9.34\end{array}$ & $\begin{array}{c}13.57 \\
4.7 \\
0.00\end{array}$ & $\begin{array}{l}43.90 \\
36.89 \\
17.30\end{array}$ & $\begin{array}{r}13.89 \\
8.04 \\
3.29\end{array}$ & $\begin{array}{l}4.56 \\
1.72 \\
0.00\end{array}$ & $\begin{array}{r}18.15 \\
8.05 \\
3.31\end{array}$ & $\begin{array}{c}16.02 \\
0.20 \\
0.61\end{array}$ & $\begin{array}{r}21.35 \\
6.83 \\
0.56\end{array}$ & $\begin{array}{l}16.16 \\
5.64 \\
0.00\end{array}$ \\
\hline Horse Beans (straw)... & $\begin{array}{l}\max \\
\text { med }\end{array}$ & 9 & $\begin{array}{l}7.94 \\
5.35 \\
3.65\end{array}$ & $\begin{array}{ll}47 & 21 \\
42 & 16 \\
37.22\end{array}$ & $\begin{array}{l}8.61 \\
2.45 \\
1.75\end{array}$ & $\begin{array}{l}29.59 \\
22.40 \\
10.03\end{array}$ & $\begin{array}{r}11.71 \\
7.58 \\
5.66\end{array}$ & $\begin{array}{l}2.67 \\
1.26 \\
0.31\end{array}$ & $\begin{array}{l}8.80 \\
7.39 \\
5.03\end{array}$ & $\begin{array}{l}8.37 \\
3.55 \\
0.00\end{array}$ & $\begin{array}{r}13.93 \\
7.37 \\
2.39\end{array}$ & $\begin{array}{r}14.97 \\
5.84 \\
0.00\end{array}$ \\
\hline Kapeseed (stram).... & $\begin{array}{l}\text { max. } \\
\text { med. } \\
\text { nin. }\end{array}$ & 14 & $\begin{array}{l}6.63 \\
4.92 \\
3.51 \\
\end{array}$ & $\begin{array}{r}88.76 \\
27.28 \\
983\end{array}$ & $\begin{array}{c}25.35 \\
9.34 \\
0.00\end{array}$ & $\begin{array}{l}35.47 \\
28.37 \\
19.66\end{array}$ & $\begin{array}{r}15.40 \\
6.01 \\
2.78\end{array}$ & $\begin{array}{l}5.52 \\
1.84 \\
6.00\end{array}$ & $\begin{array}{r}11.82 \\
5.96 \\
1.23\end{array}$ & $\begin{array}{r}18.06 \\
7.59 \\
1.43\end{array}$ & $\begin{array}{r}17.12 \\
6.34 \\
0.60\end{array}$ & $\begin{array}{r}24.40 \\
8.37 \\
0.00\end{array}$ \\
\hline Flaxseed (straw) $\ldots . .$. & $\begin{array}{l}\max \\
\text { med. } \\
\text { min }\end{array}$ & 16 & $\begin{array}{l}4.44 \\
3.53 \\
2.06\end{array}$ & $\begin{array}{r}45.95 \\
31.06 \\
9.70\end{array}$ & $\begin{array}{l}29.65 \\
814 \\
0.00\end{array}$ & $\begin{array}{l}28.09 \\
-22.23 \\
14.90\end{array}$ & $\begin{array}{r}11.74 \\
6.58 \\
3.50\end{array}$ & $\begin{array}{l}6.62 \\
2.40 \\
1.02\end{array}$ & $\begin{array}{r}296 \\
13.59 \\
8.03\end{array}$ & $\begin{array}{r}13.42 \\
6.51 \\
3.38\end{array}$ & $\begin{array}{r}14.22 \\
5.51 \\
1.47\end{array}$ & $\begin{array}{l}8.59 \\
4.09 \\
0.62\end{array}$ \\
\hline Potato (tuber)........ & $\begin{array}{l}\max \\
\text { med. } \\
\text { min. }\end{array}$ & 53 & $\begin{array}{l}5.5 \\
3.78 \\
2.20\end{array}$ & $\begin{array}{l}75.61 \\
60.37 \\
43.95\end{array}$ & $\begin{array}{c}16.93 \\
2.62 \\
0.00\end{array}$ & $\begin{array}{l}6.28 \\
2.57 \\
0.51\end{array}$ & $\begin{array}{r}13.58 \\
4.69 \\
1.32\end{array}$ & $\begin{array}{l}7.18 \\
1.18 \\
0.04\end{array}$ & $\begin{array}{r}27.14 \\
17.23 \\
8.39\end{array}$ & $\begin{array}{r}14.89 \\
6.49 \\
0.44\end{array}$ & $\begin{array}{l}8.11 \\
7.13 \\
0.00\end{array}$ & $\begin{array}{r}10.75 \\
3.11 \\
0.85\end{array}$ \\
\hline Beets (for cattls)..... & $\begin{array}{l}\max \\
\text { med. } \\
\text { min. }\end{array}$ & 15 & $\begin{array}{l}9.27 \\
6.44 \\
4.41\end{array}$ & $\begin{array}{l}69.40 \\
51.0 \\
25.57\end{array}$ & $\begin{array}{r}39.20 \\
15.9 \\
5.80\end{array}$ & $\begin{array}{l}8.78 \\
4.19 \\
2.17\end{array}$ & $\begin{array}{l}7.90 \\
4.54 \\
2.11\end{array}$ & \begin{tabular}{ll|}
3.11 \\
0.82 \\
0.39
\end{tabular} & $\begin{array}{r}13.02 \\
8.4 \bar{j} \\
1.95\end{array}$ & $\begin{array}{l}6.04 \\
3.17 \\
2.41\end{array}$ & $\begin{array}{r}10.02 \\
2.83 \\
0.60\end{array}$ & $\begin{array}{r}35.45 \\
8.40 \\
1.86\end{array}$ \\
\hline Sugar Bee & $\begin{array}{l}\max \\
\text { med. } \\
\text { min }\end{array}$ & 98 & $\begin{array}{l}6.56 \\
3.86 \\
2.45\end{array}$ & $\begin{array}{l}78.11 \\
55.11 \\
39.70\end{array}$ & $\begin{array}{l}24.08 \\
10.00 \\
0.97\end{array}$ & $\begin{array}{r}12.20 \\
5.26 \\
1.59\end{array}$ & $\begin{array}{r}11.62 \\
7.53 \\
2.34\end{array}$ & $\begin{array}{l}3.17 \\
1.93 \\
0.20\end{array}$ & $\begin{array}{l}1845 \\
10.94 \\
631\end{array}$ & $\begin{array}{l}889 \\
3.81 \\
1.27\end{array}$ & $\begin{array}{l}9.00 \\
1.80 \\
0.77\end{array}$ & $\begin{array}{r}10.95 \\
5.18 \\
0.52\end{array}$ \\
\hline Turnips (root)..... & $\begin{array}{l}\max \\
\text { med. } \\
\text { min }\end{array}$ & 32 & $\begin{array}{r}1397 \\
8.0 ! \\
4.89\end{array}$ & $\begin{array}{l}62.68 \\
45.40 \\
26.55\end{array}$ & $\begin{array}{l}20.71 \\
9.51 \\
0.00\end{array}$ & $\begin{array}{r}15.90 \\
10.60 \\
5.47\end{array}$ & $\begin{array}{l}6.41 \\
3.69 \\
1.61\end{array}$ & $\begin{array}{l}2.55 \\
0.81 \\
0.19\end{array}$ & $\begin{array}{r}18.94 \\
12.71 \\
5.48\end{array}$ & $\begin{array}{r}18.07 \\
11.19 \\
2.62\end{array}$ & $\begin{array}{l}7.96 \\
1.87 \\
0.00\end{array}$ & $\begin{array}{r}13.85 \\
5.07 \\
1.35\end{array}$ \\
\hline Carrots (root). & $\begin{array}{l}\max \\
\text { med. } \\
\text { min. }\end{array}$ & 11 & $\begin{array}{l}8.04 \\
5.58 \\
4.34\end{array}$ & $\begin{array}{l}53.3 \\
35.2 \\
17.0\end{array}$ & $\begin{array}{l}34.75 \\
22.07 \\
10.92\end{array}$ & $\begin{array}{c}16.52 \\
11.42 \\
6.35\end{array}$ & $\mid \begin{array}{l}7.28 \\
4.73 \\
1.54\end{array}$ & $\begin{array}{l}2.02 \\
108 \\
0.00\end{array}$ & $\begin{array}{r}15.02 \\
12.46 \\
9.55\end{array}$ & $\begin{array}{l}11.78 \\
6.72 \\
3.49\end{array}$ & $\begin{array}{l}5.72 \\
2.47 \\
0.90\end{array}$ & $\begin{array}{r}10.49 \\
5.19 \\
0.69\end{array}$ \\
\hline
\end{tabular}


COMPARATIVE STATEMENT, \&C.-continuea:

\begin{tabular}{|c|c|c|c|c|c|c|c|c|c|c|c|c|}
\hline \multirow{2}{*}{\multicolumn{2}{|c|}{ DESCRIPTION. }} & \multirow{2}{*}{ 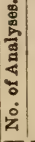 } & \multirow[b]{2}{*}{$\frac{8}{4}$} & \multicolumn{9}{|c|}{ IN 100 PARTS OF PUKE ASHES, } \\
\hline & & & & 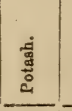 & 离 & 弯 & 离 & 茝 & 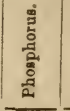 & 总 & 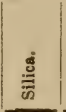 & 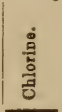 \\
\hline Sea-kale (root)....... & $\begin{array}{l}\max \\
\operatorname{med} \\
\min \end{array}$ & 15 & $\begin{array}{r}5.25 \\
3.35 \\
2.29\end{array}$ & $\mid \begin{array}{lll}54 & 91 & 2 \\
38 & 30 & 1 \\
27.94\end{array}$ & $\begin{array}{r}24.74 \\
15.68 \\
2.75\end{array}$ & $\begin{array}{r}10.78 \\
7.02 \\
4.41\end{array}$ & $\begin{array}{l}8.11 \\
4.69 \\
1.30\end{array}$ & $\begin{array}{l}7.19 \\
2.51 \\
076\end{array}$ & $\begin{array}{r}16.33 \\
12.49 \\
8.68\end{array}$ & $\begin{array}{r}15.13 \\
7.93 \\
5.13\end{array}$ & $\begin{array}{r}17.21 \\
4.93 \\
1.07\end{array}$ & $\begin{array}{r}10.59 \\
6.95 \\
1.80\end{array}$ \\
\hline Potato (straw)....... & $\begin{array}{c}\max \\
\text { med. } \\
\text { min. }\end{array}$ & & $\begin{array}{r}12.89 \\
8.58 \\
5.16\end{array}$ & $\begin{array}{r}42.78 \\
21.78 \\
6.38\end{array}$ & $\begin{array}{l}7.44 \\
2.31 \\
0.001\end{array}$ & $\begin{array}{l}46.70 \\
32.65 \\
16.12\end{array}$ & $\begin{array}{r}28.47 \\
16.51 \\
6.98\end{array}$ & $\begin{array}{l}4.32 \\
2.80 \\
1.82\end{array}$ & $\mid \begin{array}{r}12.14 \\
7.89 \\
2.60\end{array}$ & $\begin{array}{l}7.93 \\
6.32 \\
4.90\end{array}$ & $\begin{array}{l}9.40 \\
4.32 \\
1.93\end{array}$ & $\begin{array}{l}10.45 \\
5.78 \\
2.79\end{array}$ \\
\hline Beet (for cattle-leaves) & $\begin{array}{l}\max \\
\text { med. }\end{array}$ & 13 & $\begin{array}{l}20.95 \\
15.18 \\
11.10\end{array}$ & $\begin{array}{r}45.89 \\
30.75 \\
5.961\end{array}$ & $\begin{array}{l}34.56 \\
20.29 \\
10.44\end{array}$ & $\begin{array}{r}13.92 \\
11.10 \\
7.82\end{array}$ & $\begin{array}{r}14.52 \\
9.51 \\
6.68\end{array}$ & $\begin{array}{l}2.67 \\
1.45 \\
0.51\end{array}$ & $\begin{array}{l}7.27 \\
5.46 \\
2.08\end{array}$ & $\begin{array}{r}10.20 \\
5.97 \\
3.08\end{array}$ & $\begin{array}{l}8.27 \\
3.60 \\
1.15\end{array}$ & $\begin{array}{l}26.70 \\
14.86 \\
1.40\end{array}$ \\
\hline Sugar Beet (leaves)... & $\begin{array}{l}\max . \\
\text { med. } \\
\text { min. }\end{array}$ & 10 & $\begin{array}{r}29.23 \\
17.58 \\
8.30\end{array}$ & $\begin{array}{l}39.961 \\
28.481 \\
12.62\end{array}$ & $\begin{array}{c}19.40 \\
14.65 \\
6.79\end{array}$ & $\begin{array}{r}19.66 \\
14.65 \\
5.73\end{array}$ & $\begin{array}{r}20.40 \\
14.98 \\
6.84\end{array}$ & $\begin{array}{l}2.33 \\
0.98 \\
0.17\end{array}$ & $\begin{array}{r}15.491 \\
6.93 \\
2.77\end{array}$ & $\begin{array}{r}11.09 \\
5.19 \\
1.89\end{array}$ & $\begin{array}{l}5.58 \\
3.21 \\
1.49\end{array}$ & $\begin{array}{r}26.78 \\
11.47 \\
3.66\end{array}$ \\
\hline Turnips (leaves)..... & $\begin{array}{l}\text { max. } \\
\text { med. } \\
\text { min. }\end{array}$ & 10 & $\begin{array}{r}15.39 \\
11.64 \\
7.81\end{array}$ & $\left|\begin{array}{lll}86 & 68 \\
23 & 43 \\
12.32\end{array}\right|$ & $\begin{array}{r}20.26 \\
9.45 \\
3.96\end{array}$ & $\begin{array}{l}40.78 \\
32.92 \\
25.56\end{array}$ & $\begin{array}{l}9.25 \\
3.96 \\
1.00\end{array}$ & $\begin{array}{l}3.29 \\
1.58 \\
0.71\end{array}$ & $\begin{array}{r}14.281 \\
7.30 \\
2.43\end{array}$ & \begin{tabular}{|r|}
15.27 \\
9.40 \\
4.97
\end{tabular} & $\begin{array}{l}8.57 \\
3.83 \\
0.00\end{array}$ & $\begin{array}{r}16.30 \\
10.13 \\
245\end{array}$ \\
\hline Carrots (leaves) .... & $\begin{array}{l}\max . \\
\operatorname{med} . \\
\min .\end{array}$ & & \begin{tabular}{|r|}
17.83 \\
13.53 \\
8.42
\end{tabular} & $\begin{array}{r}22.26 \\
11.26 \\
7.65\end{array}$ & $\begin{array}{r}28.70 \\
19.83 \\
8.81\end{array}$ & $\begin{array}{l}41.79 \\
32.75 \\
21.29\end{array}$ & $\begin{array}{l}6.70 \\
3.46 \\
1.16\end{array}$ & $\begin{array}{ll}4 & 85 \\
2.51 \\
0.59\end{array}$ & $\begin{array}{l}8.09 \\
4.42 \\
1.44\end{array}$ & $\begin{array}{l}9.90 \\
7.49 \\
4.28\end{array}$ & $\begin{array}{r}24.58 \\
11.26 \\
2.40\end{array}$ & $\begin{array}{r}14.36 \\
8.93 \\
2.72\end{array}$ \\
\hline Sea-kale (leaves).... & $\begin{array}{l}\max \\
\text { med. } \\
\text { min }\end{array}$ & 10 & $\begin{array}{r}12.46 \\
10.98 \\
8.38\end{array}$ & $\begin{array}{l}5995 \\
26.181 \\
11.46\end{array}$ & $\begin{array}{r}28.08 \\
17.63 \\
4.06\end{array}$ & $\begin{array}{ll}26 & 13 \\
19.67 \\
13.53\end{array}$ & $\begin{array}{ll}6 & 47 \\
2.42 \\
1.12\end{array}$ & \begin{tabular}{rr|}
3 & .31 \\
1 & 87 \\
0.80
\end{tabular} & $\begin{array}{l}8.99 \\
6.30 \\
4.68\end{array}$ & $\begin{array}{rr}10.69 \\
8 & 61 \\
5 & 41\end{array}$ & $\begin{array}{l}6.17 \\
3.46 \\
1.02\end{array}$ & $\begin{array}{r}22.90 \\
16.19 \\
2.00\end{array}$ \\
\hline Hops..... . & $\begin{array}{c}\max \\
\text { med. } \\
\text { min }\end{array}$ & 25 & $\begin{array}{r}15.27 \\
7.59 \\
5.31\end{array}$ & $\begin{array}{l}51.61 \\
34.45 \\
16.31\end{array}$ & $\begin{array}{l}8.78 \\
2.19 \\
0.00\end{array}$ & $\begin{array}{r}24.58 \\
16.65 \\
9.77\end{array}$ & $\begin{array}{r}1836 \\
5.47 \\
1.49\end{array}$ & $\begin{array}{l}3.18 \\
1.45 \\
0.35\end{array}$ & $\begin{array}{r}22.61 \\
16.70 \\
9.20\end{array}$ & $\begin{array}{r}12.23 \\
3.58 \\
000\end{array}$ & $\begin{array}{l}26.06 \\
16.61) \\
10.48\end{array}$ & $\begin{array}{l}6.95 \\
3.28 \\
2.12\end{array}$ \\
\hline Hops (leaves)..... & $\begin{array}{l}\max . \\
\operatorname{med} . \\
\min .\end{array}$ & & \begin{tabular}{|l|}
28.35 \\
18.04 \\
13.08
\end{tabular} & $\begin{array}{r}16.58 \\
12.43 \\
5.71\end{array}$ & $\begin{array}{l}6.134 \\
3.80 \\
1.57\end{array}$ & $\begin{array}{l}49.68 \\
42.55 \\
34.98\end{array}$ & $\begin{array}{r}11.61 \\
6.45 \\
2.38\end{array}$ & $\begin{array}{l}2.41 \\
0.89 \\
0.12\end{array}$ & $\begin{array}{r}11.62 \\
6.08 \\
3.52\end{array}$ & $\begin{array}{l}9.13 \\
412 \\
1.77\end{array}$ & $\begin{array}{l}29.13 \\
21.56 \\
12.14\end{array}$ & $\begin{array}{l}5.76 \\
2.78 \\
0.00\end{array}$ \\
\hline Hops (bine)......... & $\begin{array}{l}\max \\
\text { med. } \\
\text { min }\end{array}$ & 5 & $\begin{array}{l}6.41 \\
4.85 \\
8.74\end{array}$ & $\begin{array}{l}31.15 \\
28.03 \\
17.11\end{array}$ & $\begin{array}{r}10.17 \\
4.04 \\
1.58\end{array}$ & $\begin{array}{l}39.73 \\
3088 \\
22.94\end{array}$ & $\begin{array}{r}16.61 \\
6.68 \\
4.12\end{array}$ & $\begin{array}{l}2.51 \\
0.88 \\
0.21\end{array}$ & $\begin{array}{r}13.70 \\
10.78 \\
6.92\end{array}$ & $\begin{array}{l}4.14 \\
3.26 \\
2.64\end{array}$ & $\begin{array}{r}11.84 \\
8.46 \\
6.07\end{array}$ & $\begin{array}{r}10.22 \\
9.07 \\
8.02\end{array}$ \\
\hline Tobacco (leaves)..... & $\begin{array}{l}\max . \\
\text { med. } \\
\text { min. }\end{array}$ & 12 & $\begin{array}{l}22.93 \\
18.41 \\
17.16\end{array}$ & $\begin{array}{l}30.98 \\
20.07 \\
11.43\end{array}$ & $\begin{array}{l}7.88 \\
3.39 \\
137\end{array}$ & $\begin{array}{l}52.03 \\
41.59 \\
27.10\end{array}$ & $\begin{array}{r}15.73 \\
11.72 \\
7.22\end{array}$ & $\begin{array}{l}4.55 \\
3.07 \\
0.57\end{array}$ & $\begin{array}{l}4.77 \\
3.16 \\
1.97\end{array}$ & $\begin{array}{l}5.94 \\
386 \\
2.78\end{array}$ & $\begin{array}{l}18.39 \\
8.92 \\
4.51\end{array}$ & $\begin{array}{l}11.14 \\
5.22 \\
0.55\end{array}$ \\
\hline Wine (must) ......... & $\begin{array}{l}\text { max. } \\
\text { med. } \\
\text { min. }\end{array}$ & & $\begin{array}{l}0.410 \\
0.277 \\
0.162\end{array}$ & $\begin{array}{l}71.85 \\
6367 \\
51.97\end{array}$ & $\begin{array}{l}3.66 \\
1.04 \\
0.00\end{array}$ & $\begin{array}{l}7.46 \\
5.05 \\
3.87\end{array}$ & $\begin{array}{r}10.6 ? \\
5.47 \\
3.27\end{array}$ & $\begin{array}{l}0.73 \\
0.37 \\
0.00\end{array}$ & $\begin{array}{l}25.43 \\
17.23 \\
14.07\end{array}$ & $\begin{array}{l}5.93 \\
3.56 \\
0.00\end{array}$ & $\begin{array}{l}2.18 \\
1.62 \\
0.37\end{array}$ & $\begin{array}{l}5.82 \\
1.42 \\
0.00\end{array}$ \\
\hline Graperine . & $\begin{array}{l}\max . \\
\text { med. } \\
\text { min. }\end{array}$ & 19 & $\begin{array}{l}3.69 \\
2.89 \\
2.11\end{array}$ & & $\begin{array}{r}28.61 \\
11.10 \\
0.29\end{array}$ & $\begin{array}{l}46.56 \\
34.68 \\
25.58\end{array}$ & $\begin{array}{l}9.16 \\
5.19 \\
0.19\end{array}$ & $\begin{array}{l}5.50 \\
1.31 \\
0.16\end{array}$ & $\begin{array}{r}20.81 \\
12.64 \\
5.25\end{array}$ & $\begin{array}{l}3.64 \\
2.13 \\
0.81\end{array}$ & $\begin{array}{l}3.18 \\
1.66 \\
0.00\end{array}$ & $\begin{array}{l}8.65 \\
0.89 \\
0.09\end{array}$ \\
\hline Mulberry (leaves).... & $\begin{array}{l}\text { max. } \\
\text { med. } \\
\text { min. }\end{array}$ & 15 & $\begin{array}{r}13.43 \\
10.89 \\
7.48\end{array}$ & $\begin{array}{l}31.27 \\
23.87 \\
16.37\end{array}$ & $\begin{array}{l}2.76 \\
1.36 \\
0.00\end{array}$ & $\begin{array}{l}40.59 \\
32.78 \\
27.67\end{array}$ & $\begin{array}{r}12.48 \\
6.34 \\
3.04\end{array}$ & $\begin{array}{l}1.94 \\
1.13 \\
0.74\end{array}$ & $\begin{array}{r}12.65 \\
784 \\
3.51\end{array}$ & $\begin{array}{l}4.64 \\
184 \\
0.12\end{array}$ & $\begin{array}{l}37.71 \\
26.71 \\
1.45\end{array}$ & $\begin{array}{l}3.15 \\
1.23 \\
0.00\end{array}$ \\
\hline Sugar Beets (pressed). & $\begin{array}{l}\text { max. } \\
\text { med. } \\
\text { min. }\end{array}$ & $\mid 11$ & $\begin{array}{l}5.05 \\
1.70 \\
2.78\end{array}$ & $\begin{array}{l}53.80 \\
34.53 \\
3.20 .84\end{array}$ & $\mid \begin{array}{r}18.46 \\
7.98 \\
2.45\end{array}$ & $\left|\begin{array}{ll}30.72 \\
22 & .35 \\
11 & 59\end{array}\right|$ & $\begin{array}{l}22.27 \\
6.52 \\
0.00\end{array}$ & $\begin{array}{l}6.76 \\
8.05 \\
0.96\end{array}$ & $\mid \begin{array}{r}19.13 \\
9.84 \\
4.16\end{array}$ & $\begin{array}{l}6.48 \\
3.33 \\
1.45\end{array}$ & $\begin{array}{l}25.23 \\
7.72 \\
0.00\end{array}$ & $\begin{array}{l}21.40 \\
3.60 \\
0.35\end{array}$ \\
\hline
\end{tabular}


COMPARATIVE STATEMENT, dC.-continued.

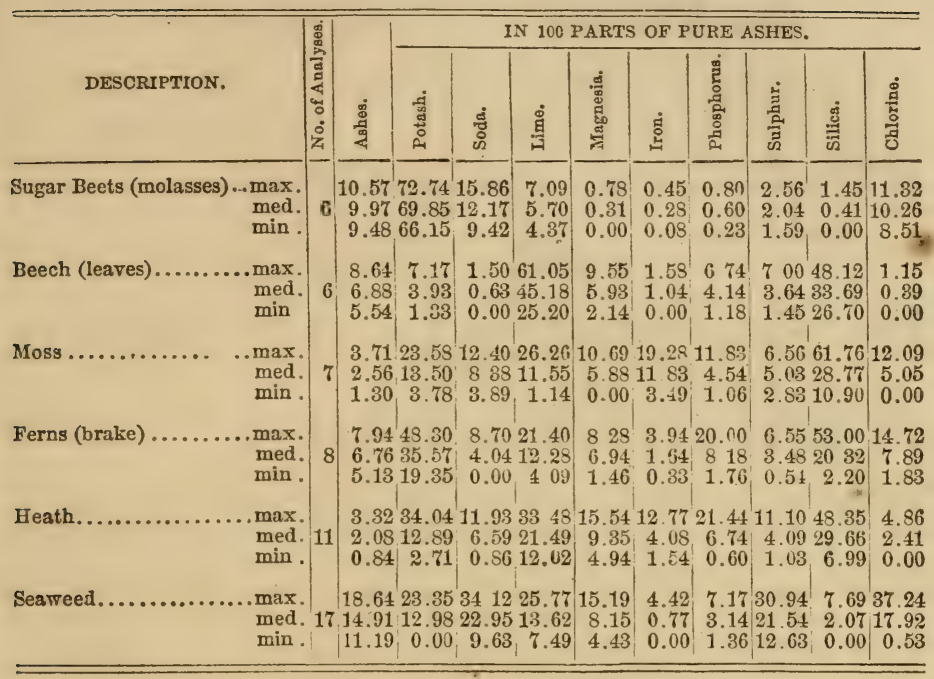




\section{COMPARATIVE STATEMENT}

SHOWING THE INFLUENCE UPON THE ASHES OF PLANTS

OF THE

AIIKAII SAITS, POTASI AII SODA, WHEN PIESENT IN EITHET A MAXIMUM, MEDIUM, OR MINIMCM QUANTITY.

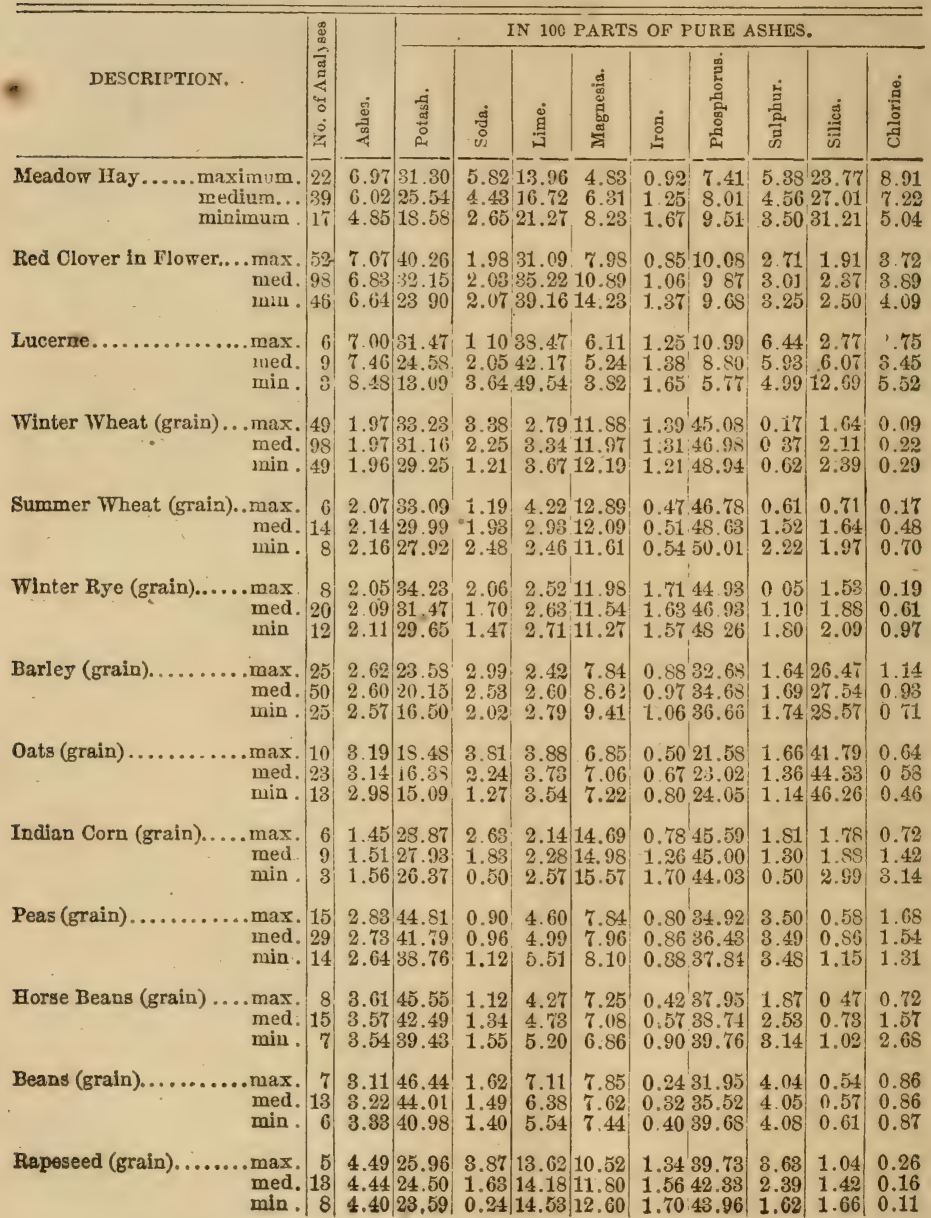


COMPARATIVE STATEMENT, \&c.-continued.

\begin{tabular}{|c|c|c|c|c|c|c|c|c|c|c|c|c|}
\hline \multirow{2}{*}{\multicolumn{2}{|c|}{ DESCRIPTION. }} & \multirow{2}{*}{ 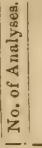 } & \multirow[b]{2}{*}{ 剂 } & \multicolumn{9}{|c|}{ IN 100 PARTS OF PURE ASHES. } \\
\hline & & & & 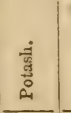 & 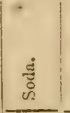 & 苛 & 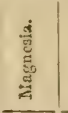 & 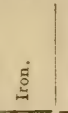 & 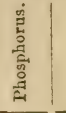 & 竎 & 离 & 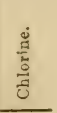 \\
\hline Flaxseed (gra & $\begin{array}{l}\max \\
\operatorname{med} \\
\min \end{array}$ & $\mid \begin{array}{l}2 \\
5 \\
3 \\
\end{array}$ & $\begin{array}{l}3.36 \\
3.69 \\
3.91 \\
\end{array}$ & $\begin{array}{l}34.26 \\
30.63 \\
28.21\end{array}$ & $\begin{array}{l}1.59 \\
2.07 \\
2.19\end{array}$ & $\begin{array}{l}8.421 \\
8.101 \\
7591\end{array}$ & $\begin{array}{l}1314 \\
14.29 \\
15.16\end{array}$ & $\begin{array}{l}0.503 \\
1124 \\
1.514\end{array}$ & $\begin{array}{l}35.63 \\
41.50 \\
43.41\end{array}$ & $\begin{array}{l}1.5 \pi \\
2.54 \\
2.83\end{array}$ & $\begin{array}{l}1.46 \\
1.24 \\
1.10\end{array}$ & $\begin{array}{l}0.52 \\
0.17 \\
0.15\end{array}$ \\
\hline Winter Wheat (straw).. & $\begin{array}{l}\max \\
\text { med. } \\
\text { min. }\end{array}$ & $\begin{array}{r}8 \\
18 \\
10\end{array}$ & $\begin{array}{l}5.17 \\
5.37 \\
5.56\end{array}$ & $\begin{array}{l}1836 \\
18.65 \\
11.32\end{array}$ & $\begin{array}{l}3.08 \\
1.38 \\
0.52\end{array}$ & $\begin{array}{l}5.42 \\
5.16 \\
5.83\end{array}$ & $\begin{array}{l}2.06 \\
2.43 \\
2.82\end{array}$ & $\begin{array}{l}0.63 \\
0.61 \\
0.63\end{array}$ & $\begin{array}{l}3.76 \\
4.81 \\
5.67\end{array}$ & $\begin{array}{l}2.256 \\
2.456 \\
2.616\end{array}$ & $\begin{array}{l}64.73 \\
67.50 \\
69.69\end{array}$ & $\begin{array}{l}2.35 \\
1.68 \\
1.26\end{array}$ \\
\hline Summer Wheat (straw) & $\begin{array}{l}\text { max. } \\
\text { med. } \\
\text { min. }\end{array}$ & $\begin{array}{l}4 \\
7 \\
3\end{array}$ & $\begin{array}{l}4.40 \\
4.45 \\
4.54\end{array}$ & $\begin{array}{l}36.07 \\
28.91 \\
19.35\end{array}$ & $\begin{array}{l}110 \\
2.69 \\
447\end{array}$ & $\begin{array}{r}3.14 \\
6.89 \\
11.91\end{array}$ & $\begin{array}{l}1.91 \\
2.45 \\
3.12\end{array}$ & $\begin{array}{l}0.25 \\
0.72 \\
1.34\end{array}$ & $\begin{array}{l}5.25 \\
5.15 \\
5.01\end{array}$ & $\begin{array}{l}3.604 \\
3.134 \\
2.51\end{array}$ & $\begin{array}{l}46.40 \\
47.60 \\
49.18\end{array}$ & $\begin{array}{l}1.81 \\
2.19 \\
3.17\end{array}$ \\
\hline Winter Rye (straw)... & $\begin{array}{l}\max \\
\text { med. }\end{array}$ & $\begin{array}{r}5 \\
10 \\
5\end{array}$ & $\begin{array}{l}4.41 \\
4.79 \\
5.26\end{array}$ & $\begin{array}{l}22.70 \\
19.24 \\
15.79\end{array}$ & $\begin{array}{l}1.09 \\
215 \\
2.30\end{array}$ & $\begin{array}{l}9.28 \\
8.59 \\
7.78\end{array}$ & $\begin{array}{l}2.67 \\
2.72 \\
2.77\end{array}$ & $\begin{array}{l}0.8 S \\
104 \\
1.20\end{array}$ & $\begin{array}{l}5.23 \\
5.14 \\
5.05\end{array}$ & $\begin{array}{l}2.965 \\
2.715 \\
2.456\end{array}$ & $\begin{array}{l}51.60 \\
5638 \\
60.98\end{array}$ & $\begin{array}{l}2.95 \\
2.51 \\
2.07\end{array}$ \\
\hline Barley (straw).... & $\begin{array}{l}\max \text {. } \\
\text { medin. }\end{array}$ & $\begin{array}{r}12 \\
21 \\
9\end{array}$ & $\begin{array}{l}4.76 \\
4.80 \\
4.91\end{array}$ & $\begin{array}{ll}29 & 51 \\
22.85 \\
13.89\end{array}$ & $\begin{array}{l}4.23 \\
4.13 \\
3.99\end{array}$ & $\begin{array}{l}7.42 \\
7.77 \\
8.26\end{array}$ & $\begin{array}{l}2.46 \\
2.60 \\
2.78\end{array}$ & $\begin{array}{l}0.14 \\
0.69 \\
1.26\end{array}$ & $\begin{array}{l}4.14 \\
4.48 \\
4.94\end{array}$ & $\begin{array}{l}4.524 \\
3715 \\
2.635\end{array}$ & $\begin{array}{l}46.48 \\
52.012 \\
5984\end{array}$ & $\begin{array}{l}1.97 \\
2.26 \\
2.61\end{array}$ \\
\hline Oats (straw)......... & $\begin{array}{l}\max . \\
\text { med. } \\
\text { min. }\end{array}$ & $\begin{array}{l}5 \\
9 \\
4\end{array}$ & $\begin{array}{l}5.11 \\
4.70 \\
4.30\end{array}$ & $\begin{array}{l}25.14 \\
2.2 .12 \\
19.08\end{array}$ & $\begin{array}{l}4.17 \\
2.89 \\
1.61\end{array}$ & $\begin{array}{r}7 . \$ 2 \\
8.56 \\
10.16\end{array}$ & $\begin{array}{l}4.15 \\
4.04 \\
3.59\end{array}$ & $\begin{array}{l}1.32 \\
1.45 \\
1.62\end{array}$ & $\begin{array}{l}4.60 \\
4.69 \\
4.81\end{array}$ & $\begin{array}{l}3.034 \\
3.294 \\
3.674\end{array}$ & $\begin{array}{l}46.27 \\
49.57 \\
48.95\end{array}$ & $\begin{array}{l}4.62 \\
631 \\
7.91\end{array}$ \\
\hline Peas (straw).. & $\begin{array}{l}\text { max. } \\
\text { med. }\end{array}$ & $\begin{array}{r}9 \\
23 \\
14\end{array}$ & $\begin{array}{l}4.95 \\
5.13 \\
5.19\end{array}$ & $\begin{array}{l}28.95 \\
22.90 \\
17.93\end{array}$ & $\begin{array}{l}3.48 \\
4.07 \\
4.52\end{array}$ & $\begin{array}{l}84.55 \\
36.82 \\
40.43\end{array}$ & $\begin{array}{l}7.23 \\
5.01 \\
8.42\end{array}$ & $\begin{array}{l}1.72 \\
1.72 \\
1.71\end{array}$ & $\begin{array}{l}7.06 \\
8.05 \\
8.65\end{array}$ & $\begin{array}{l}6.35 \\
6.26 \\
6.19\end{array}$ & $\begin{array}{l}454 \\
6.83 \\
8.27\end{array}$ & $\begin{array}{l}6.83 \\
5.61 \\
5.10\end{array}$ \\
\hline Horse Beans. (straw)... & $\begin{array}{c}\max \\
\text { medr. } \\
\text { mir. }\end{array}$ & $\begin{array}{l}4 \\
9 \\
5\end{array}$ & $\begin{array}{l}5.02 \\
5.25 \\
5.53\end{array}$ & $\begin{array}{l}4.81 \\
12.16 \\
1017\end{array}$ & $\begin{array}{l}2.75 \\
2.45 \\
2.21\end{array}$ & $\begin{array}{l}18.46 \\
22.40 \\
25.55\end{array}$ & $\begin{array}{l}7.53 \\
7.53 \\
7.62\end{array}$ & $\begin{array}{l}0.93 \\
1.26 \\
152\end{array}$ & $\begin{array}{l}8.29 \\
7.39 \\
6.68\end{array}$ & $\begin{array}{l}4.64 \\
3.55 \\
2.67\end{array}$ & $\begin{array}{l}7.89 \\
7.37 \\
6.57\end{array}$ & $\begin{array}{l}4.29 \\
5.84 \\
7.09\end{array}$ \\
\hline Rapeseed (straw)... & $\begin{array}{c}\max . \\
\text { mell. } \\
\text { min. }\end{array}$ & $\begin{array}{r}7 \\
14 \\
7\end{array}$ & $\begin{array}{l}5.56 \\
4.92 \\
4.28\end{array}$ & & $\begin{array}{r}6.01 \\
9.84 \\
12.67\end{array}$ & $\begin{array}{l}26.10 \\
23.37 \\
30.62\end{array}$ & $\begin{array}{l}5.77 \\
6.01 \\
6.25\end{array}$ & $\begin{array}{l}1.97 \\
1.84 \\
1.70\end{array}$ & $\begin{array}{l}5.40 \\
5.96 \\
6.53\end{array}$ & $\begin{array}{l}8.32 \\
7.59 \\
6.86\end{array}$ & $\begin{array}{l}6.27 \\
6.34 \\
6.41\end{array}$ & $\begin{array}{l}6.90 \\
8.37 \\
9.85\end{array}$ \\
\hline Flaxseed (straw) ..... & $\begin{array}{l}\max \\
\text { med. } \\
\text { min }\end{array}$ & $\begin{array}{r}9 \\
16 \\
7\end{array}$ & $\begin{array}{l}3.43 \\
3.53 \\
3.65\end{array}$ & $\begin{array}{l}35.01 \\
81.06 \\
26.42\end{array}$ & $\begin{array}{l}7.92 \\
8.14 \\
8.42\end{array}$ & $\begin{array}{ll}21 & 84 \\
22.23 \\
22.73\end{array}$ & $\begin{array}{l}6.23 \\
6.58 \\
7.04\end{array}$ & $\begin{array}{l}2.191 \\
2.401 \\
2.671\end{array}$ & $\begin{array}{l}12.73 \\
13.59 \\
14.70\end{array}$ & $\begin{array}{l}6.21 \\
6.54 \\
6.98\end{array}$ & $\begin{array}{l}4.82 \\
5.51 \\
6.31\end{array}$ & $\begin{array}{l}3.18 \\
4.09 \\
5.24\end{array}$ \\
\hline Potato (tuber).. & $\begin{array}{l}\max \text {. } \\
\text { medin. }\end{array}$ & $\begin{array}{l}27 \\
53 \\
26\end{array}$ & $\begin{array}{l}3.90 \\
3.77 \\
3.40\end{array}$ & $\begin{array}{l}61.98 \\
60.37 \\
55.62\end{array}$ & $\begin{array}{l}2.59 \\
2.62 \\
2.50\end{array}$ & $\begin{array}{l}2.24 \\
2.57 \\
2.91\end{array}$ & $\begin{array}{l}4.01 \\
469 \\
5.38\end{array}$ & $\begin{array}{l}1.171 \\
1.181 \\
1.191\end{array}$ & $\begin{array}{l}16.09 \\
17.33 \\
18.70\end{array}$ & $\begin{array}{l}5.18 \\
6.49 \\
8.00\end{array}$ & $\begin{array}{l}0.79 \\
2.13 \\
3.11\end{array}$ & $\begin{array}{l}3.56 \\
3.11 \\
3.00\end{array}$ \\
\hline Beets (for cattle)..... & $\begin{array}{l}\text { max. } \\
\text { med. } \\
\text { min. }\end{array}$ & $\begin{array}{r}9 \\
15 \\
6\end{array}$ & $\begin{array}{l}6.41 \\
6.44 \\
6.46\end{array}$ & $\begin{array}{l}59.57 \\
54.02 \\
45.71\end{array}$ & $\begin{array}{l}15.10 \\
15.90 \\
17.43\end{array}$ & $\begin{array}{l}3.7 \frac{1}{2} \\
4.1 \% \\
4.69\end{array}$ & $\begin{array}{l}4.41 \\
4.54 \\
4.81\end{array}$ & $\begin{array}{l}0.51 \\
0.82 \\
1.06\end{array}$ & $\begin{array}{l}8.56 \\
8.45 \\
8.52\end{array}$ & $\begin{array}{l}2.95 \\
3.17 \\
3.51\end{array}$ & $\begin{array}{l}1.31 \\
2.35 \\
3.931\end{array}$ & $\begin{array}{r}5.24 \\
8.40 \\
13.11\end{array}$ \\
\hline Sugar Beet. & $\begin{array}{l}\max . \\
\text { med. } \\
\text { min. }\end{array}$ & $\begin{array}{l}42 \\
95 \\
56\end{array}$ & $\begin{array}{l}3.69 \\
3.55 \\
3.92\end{array}$ & $\begin{array}{l}63.30 \\
55.11 \\
45.32\end{array}$ & $\begin{array}{r}9.50 \\
10.09 \\
10.53\end{array}$ & $\begin{array}{l}4.07 \\
5.36 \\
6.29\end{array}$ & $\begin{array}{l}5.36 \\
7.53 \\
0.14\end{array}$ & $\begin{array}{l}076 \\
0.931 \\
1.061\end{array}$ & $\begin{array}{r}7.85 \\
10.99 \\
1250\end{array}$ & $\begin{array}{l}2.93 \\
3.81 \\
4.58\end{array}$ & $\begin{array}{l}0.80 \\
1.80 \\
2.55\end{array}$ & $\begin{array}{l}5.54 \\
518 \\
4.75\end{array}$ \\
\hline Turnips (root).... & $\begin{array}{l}\max . \\
\text { med. } \\
\text { min. }\end{array}$ & $\begin{array}{l}16 \\
32 \\
16\end{array}$ & $\begin{array}{l}802 \\
8.01 \\
8.00\end{array}$ & $\begin{array}{l}48.93 \\
45.40 \\
41.56\end{array}$ & $\begin{array}{r}10.75 \\
9.84 \\
8.93\end{array}$ & $\begin{array}{r}9.16 \\
10.60 \\
12.58\end{array}$ & $\begin{array}{l}3.45 \\
3.69 \\
3.90\end{array}$ & $\begin{array}{l}0.651 \\
0.811 \\
1.011\end{array}$ & $\begin{array}{l}11.251 \\
12.71 \\
14.051\end{array}$ & $\begin{array}{l}10.46 \\
11.19 \\
11.79\end{array}$ & $\begin{array}{l}1.03 \\
1.87 \\
2.65\end{array}$ & $\begin{array}{l}5.89 \\
5.07 \\
4.62\end{array}$ \\
\hline Carrots (root)...... & $\begin{array}{l}\text { max. } \\
\text { med. } \\
\text { min. }\end{array}$ & $\begin{array}{r}6 \\
.11 \\
.5\end{array}$ & $\begin{array}{l}5.49 \\
5.53 \\
5.69\end{array}$ & $\begin{array}{l}42.19 \\
435.21 \\
926.53\end{array}$ & $\begin{array}{l}20.87 \\
2207 \\
23.51\end{array}$ & $\begin{array}{r}9.55 \\
11.42 \\
13.88\end{array}$ & $\begin{array}{l}4.33 \\
473 \\
5.21\end{array}$ & $\begin{array}{l}1.02 \\
1.03 \\
1.03\end{array}$ & $\begin{array}{l}11.73 \\
12.46 \\
18.36\end{array}$ & $\begin{array}{l}6.11 \\
6.72 \\
7.45\end{array}$ & $\begin{array}{l}1.38 \\
2.47 \\
3.77\end{array}$ & $\begin{array}{l}3.55 \\
5.19 \\
7.1_{6}\end{array}$ \\
\hline
\end{tabular}


COMPARATIVE STATEMENT, \&O.-continued.

\begin{tabular}{|c|c|c|c|c|c|c|c|c|c|c|c|c|}
\hline \multirow{2}{*}{\multicolumn{2}{|c|}{ DESCRIPTION. }} & \multirow{2}{*}{ 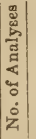 } & \multicolumn{10}{|c|}{ IN 100 PARTS OF PURE ASHES. } \\
\hline & & & 蛋 & 超 & 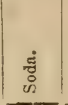 & 亶 & 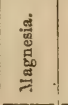 & 范 & 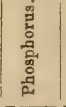 & 营 & 苞 & 竎 \\
\hline 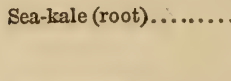 & & $\begin{array}{r}9 \\
15 \\
6\end{array}$ & $\begin{array}{l}3.38 \\
3.35 \\
3.18\end{array}$ & & $\begin{array}{l}19.06 \\
15.68 \\
10.61\end{array}$ & $\begin{array}{l}6.00 \\
7.02 \\
8.54\end{array}$ & $\begin{array}{l}3.90 \\
4.69 \\
5.89\end{array}$ & $\begin{array}{l}1.67 \\
2.51 \\
3.78\end{array}$ & $\begin{array}{l}12.46 \\
12.49 \\
12.53\end{array}$ & $\begin{array}{r}6.53 \\
7.93 \\
10.03\end{array}$ & $\begin{array}{l}3.10 \\
4.93 \\
7.69\end{array}$ & $\begin{array}{l}8.01 \\
6.95 \\
5.35\end{array}$ \\
\hline te $(5,1$ & & $\begin{array}{l}3 \\
6 \\
3\end{array}$ & $\begin{array}{l}9.14 \\
8.58 \\
8.02\end{array}$ & $\begin{array}{r}33.67 \\
21.78 \\
9.56\end{array}$ & $\begin{array}{l}169 \\
2.31 \\
2.94\end{array}$ & $\begin{array}{l}21.95 \\
32.65 \\
43.35\end{array}$ & $\begin{array}{l}12.70 \\
16.51 \\
20.32\end{array}$ & $\begin{array}{l}2.40 \\
2.80^{\circ} \\
3.32\end{array}$ & $\begin{array}{r}10.90 \\
7.89 \\
4.95\end{array}$ & $\begin{array}{l}7.21 \\
6.32 \\
5.44\end{array}$ & $\begin{array}{l}2.32 \\
4.32 \\
5.96\end{array}$ & $\begin{array}{l}6.82 \\
5.78 \\
4.75\end{array}$ \\
\hline & & $\begin{array}{r}71 \\
131 \\
61\end{array}$ & $\begin{array}{l}15.26 \\
15.18 \\
15.10\end{array}$ & & $\begin{array}{l}17.56 \\
20.29 \\
24.12\end{array}$ & $\begin{array}{l}11.18 \\
11.10 \\
10.94\end{array}$ & $\begin{array}{r}8.07 \\
9.51 \\
11.20\end{array}$ & $\begin{array}{l}1.81 \\
1.45 \\
1.04\end{array}$ & $\begin{array}{l}5.93 \\
5.46 \\
4.90\end{array}$ & $\begin{array}{l}6.85 \\
5.97 \\
5.14\end{array}$ & $\begin{array}{l}4.51 \\
360 \\
2.47\end{array}$ & $\begin{array}{r}9.51 \\
14.86 \\
17.92\end{array}$ \\
\hline & & $\begin{array}{r}51 \\
101 \\
51\end{array}$ & $\begin{array}{l}15.80 \\
17.58 \\
16.79\end{array}$ & $\begin{array}{l}36.56 \\
2 \sigma 48 \\
20.40\end{array}$ & $\begin{array}{l}14.82 \\
14.65 \\
14.47\end{array}$ & $\begin{array}{l}11.11 \\
14.65 \\
17.80\end{array}$ & & $\begin{array}{l}0.67 \\
0.98 \\
1.32\end{array}$ & $\begin{array}{l}4.63 \\
6.9 .1 \\
9.16\end{array}$ & $\begin{array}{l}3.71 \\
5.19 \\
6.66\end{array}$ & $\begin{array}{lll}2 & 18 & 1 \\
3 & 21 & 1 \\
4 & 2 & 2\end{array}$ & $\begin{array}{r}15.5 \\
11.4 \\
7.8\end{array}$ \\
\hline & & $\begin{array}{r}51 \\
101 \\
51\end{array}$ & $\begin{array}{l}10 . \\
11 . \\
12 .\end{array}$ & & $\begin{array}{r}6.96 \\
9.45 \\
11.95\end{array}$ & & $\begin{array}{l}4.50 \\
3.96 \\
3.62\end{array}$ & $\begin{array}{l}0.96 \\
1.58 \\
2.20\end{array}$ & $\begin{array}{l}5.22 \\
7.30 \\
8.57\end{array}$ & $\begin{array}{l}9.07 \\
9.40 \\
9.74\end{array}$ & $\begin{array}{l}3251 \\
3.851 \\
4.41\end{array}$ & $\begin{array}{l}10.15 \\
10.13 \\
10 \mathrm{i1}\end{array}$ \\
\hline (lenteg) & & & & & & $\begin{array}{l}33.50 \\
83.75 \\
31.08\end{array}$ & $\begin{array}{l}3.89 \\
3.46 \\
2.90\end{array}$ & $\begin{array}{l}2.54 \\
2.51 \\
2.46\end{array}$ & $\begin{array}{l}4.37 \\
4.42 \\
4.48\end{array}$ & $\begin{array}{l}7.57 \\
7.49 \\
7.39\end{array}$ & $\begin{array}{r}6.28 \\
11.26 \\
17.56\end{array}$ & $\begin{array}{r}7.44 \\
8.93 \\
10.91 \\
\end{array}$ \\
\hline 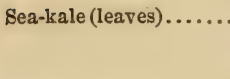 & & $\begin{array}{r}31 \\
10 \\
7\end{array}$ & $\begin{array}{ll}12 & 21 \\
10 & 98 \\
10 & 78\end{array}$ & & & & $\begin{array}{l}285 \\
2.42 \\
2.37\end{array}$ & $\begin{array}{l}1.90 \\
1.87 \\
1.86\end{array}$ & $\begin{array}{l}6.95 \\
6.30 \\
6.02\end{array}$ & $\begin{array}{l}8.88 \\
861 \\
850\end{array}$ & $\begin{array}{l}2.47 \\
3.46 \\
3.89\end{array}$ & $\begin{array}{l}10.20 \\
16.19 \\
18.76\end{array}$ \\
\hline Hor & & $\begin{array}{l}15 \\
25 \\
10\end{array}$ & $\begin{array}{l}7.29 \\
7.59 \\
8.01\end{array}$ & & $\begin{array}{l}2.40 \\
2.19 \\
1.88\end{array}$ & & $\begin{array}{l}4.98 \\
5.47 \\
6.22\end{array}$ & $\begin{array}{l}1.20 \\
1.45 \\
1.81\end{array}$ & & $\begin{array}{l}1.63 \\
3.58 \\
6.52\end{array}$ & & $\begin{array}{l}3.7 \\
3.2 \\
2.6\end{array}$ \\
\hline 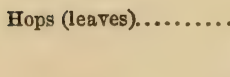 & & & & & & & $\begin{array}{l}5.07 \\
6.45 \\
8.74\end{array}$ & $\begin{array}{l}1.10 \\
0 \quad 89 \\
0.54\end{array}$ & $\begin{array}{r}7.16 \\
6.08 \\
4.26\end{array}$ & $\begin{array}{l}4.70 \\
412 \\
3.15\end{array}$ & & $\begin{array}{l}3.66 \\
2.73 \\
1.18\end{array}$ \\
\hline & $\begin{array}{l}\text { med } \\
\text { min }\end{array}$ & $\begin{array}{l}4 \\
5 \\
1\end{array}$ & $\begin{array}{l}5.10 \\
4.85 \\
3.87\end{array}$ & & $\begin{array}{r}2.51 \\
4.04 \\
10.17\end{array}$ & $\begin{array}{l}32.97 \\
3088 \\
22.94\end{array}$ & $\begin{array}{r}4.20 \\
6.68 \\
16.61\end{array}$ & $\begin{array}{l}0.47 \\
0.88 \\
2.51\end{array}$ & $\begin{array}{l}10.22 \\
10.75 \\
12.93\end{array}$ & $\begin{array}{l}3.04 \\
3.26 \\
4.14\end{array}$ & $\begin{array}{l}8.7^{4} \\
8.46 \\
7.46\end{array}$ & $\begin{array}{l}8.59 \\
9.07 \\
7.99\end{array}$ \\
\hline 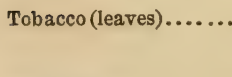 & & & & & & & $\begin{array}{r}9.69 \\
11.72 \\
13.19\end{array}$ & $\begin{array}{l}3.40 \\
3.07 \\
2.83\end{array}$ & $\begin{array}{l}3.05 \\
3.16 \\
3.24\end{array}$ & $\begin{array}{l}3.91 \\
386 \\
4.22\end{array}$ & $\begin{array}{r}10.62 \\
8.92 \\
7.71\end{array}$ & 5.32 \\
\hline Wine (must)........ & $\begin{array}{l}\max \\
\text { med } \\
\text { min }\end{array}$ & & $\begin{array}{l}0.030 \\
0.277 \\
0.162\end{array}$ & & $\begin{array}{c}1.21 \\
1.04 \\
-\end{array}$ & \begin{tabular}{|l}
4.77 \\
5.05 \\
5.68
\end{tabular} & $\begin{array}{r}4.61 \\
5.47 \\
10.62\end{array}$ & $\begin{array}{c}0.43 \\
0.37 \\
-\end{array}$ & $\begin{array}{l}15.86 \\
17.23 \\
25.43\end{array}$ & $\begin{array}{l}3.16 \\
3.56 \\
5.93\end{array}$ & $\begin{array}{l}1.84 \\
1.62 \\
0.37\end{array}$ & $\begin{array}{l}1.66 \\
1.42 \\
-\end{array}$ \\
\hline 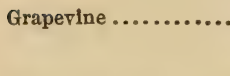 & & $\begin{array}{r}8 \\
19 \\
11\end{array}$ & $\begin{array}{l}2.97 \\
2.89 \\
2.72\end{array}$ & & & & $\begin{array}{l}3.19 \\
5.19 \\
6.65\end{array}$ & $\begin{array}{l}1.17 \\
1.31 \\
1.41\end{array}$ & & $\begin{array}{l}1.67 \\
2.13 \\
2.47\end{array}$ & $\begin{array}{l}2.00 \\
1.66 \\
1.39\end{array}$ & $\begin{array}{l}0.63 \\
0.89 \\
1.05\end{array}$ \\
\hline Mulberry (leaves).. & $\begin{array}{l}\max \\
\text { min }\end{array}$ & $\begin{array}{r}5 \\
15 \\
10\end{array}$ & $\begin{array}{l}10.43 \\
10.89 \\
11.12\end{array}$ & & $\begin{array}{l}2.15 \\
1.36 \\
0.85\end{array}$ & & $\begin{array}{l}7.40 \\
6.34 \\
5.81\end{array}$ & \begin{tabular}{|l|}
1.02 \\
1.13 \\
1.19
\end{tabular} & $\begin{array}{l}7.67 \\
7.84 \\
7.93\end{array}$ & $\begin{array}{l}2.48 \\
1.84 \\
1.52\end{array}$ & $\begin{array}{l}18.98 \\
26.71 \\
31.88\end{array}$ & $\begin{array}{l}1.6 \\
1.2 \\
1.0\end{array}$ \\
\hline esse & $\min$ & . $\begin{array}{r}4 \\
11 \\
7\end{array}$ & $\begin{array}{l}3 . \\
3 \\
3\end{array}$ & & & & $\begin{array}{l}5.10 \\
6.52 \\
7.75\end{array}$ & $\begin{array}{l}2.77 \\
3.05 \\
8.21\end{array}$ & & $\begin{array}{l}3.27 \\
3.33 \\
8.37\end{array}$ & $\begin{array}{l}6.90 \\
7.72 \\
8.18\end{array}$ & \\
\hline
\end{tabular}


COMPARATIVE STATEMENT, \&c--continued.

\begin{tabular}{|c|c|c|c|c|c|c|c|c|c|c|c|c|}
\hline \multirow[b]{2}{*}{ DESCRIPTION. } & & \multirow[b]{2}{*}{ 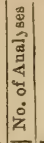 } & \multirow[b]{2}{*}{ 这 } & \multicolumn{9}{|c|}{ IN 10C PARTS OF PURE ASHE:. } \\
\hline & & & & 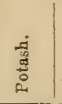 & 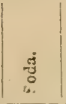 & 离 & 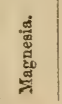 & 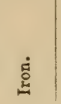 & 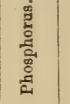 & 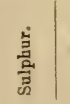 & 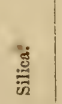 & 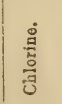 \\
\hline Sugar Beets (molasses) & $\begin{array}{l}\max \\
\text { med. } \\
\text { min. }\end{array}$ & $\begin{array}{l}3 \\
6 \\
3\end{array}$ & $\begin{array}{l}9.98 \\
9.97 \\
9.96\end{array}$ & $\begin{array}{l}71.69 \\
69.85 \\
68.63\end{array}$ & $\begin{array}{l}11.44 \\
12.17 \\
12.00\end{array}$ & $\begin{array}{l}5.35 \\
5.70 \\
6.05\end{array}$ & $\begin{array}{l}0.31 \\
0.31 \\
0.31\end{array}$ & $\begin{array}{l}0.29 \\
0.28 \\
0.26\end{array}$ & $\begin{array}{l}0.42 \\
0.60 \\
0.77\end{array}$ & $\begin{array}{l}2.10 \\
2.04 \\
1.95\end{array}$ & $\begin{array}{l}0.15 \\
0.41 \\
0.67\end{array}$ & $\begin{array}{r}9.58 \\
10.26 \\
10.94\end{array}$ \\
\hline Peach (leaves)........ & $\begin{array}{l}\max \\
\min \end{array}$ & $\begin{array}{l}3 \\
6 \\
3\end{array}$ & $\begin{array}{l}7.68 \\
6.83 \\
6.21\end{array}$ & $\begin{array}{l}6.13 \\
3.98 \\
1.73\end{array}$ & $\begin{array}{l}1.09 \\
0.63 \\
0.18\end{array}$ & $\begin{array}{l}46.36 \\
45.1 S \\
43.99\end{array}$ & $\begin{array}{l}5.22 \\
5.93 \\
6.30\end{array}$ & $\begin{array}{l}1.07 \\
1.04 \\
1.01\end{array}$ & $\begin{array}{l}4.77 \\
4.14 \\
3.51\end{array}$ & $\begin{array}{l}2.823 \\
3.643 \\
4.463\end{array}$ & $\begin{array}{l}31.56 \\
33.69 \\
35.82\end{array}$ & $\begin{array}{l}0.28 \\
0.59 \\
0.49\end{array}$ \\
\hline Moss............. & $\begin{array}{l}\max . \\
\text { med. } \\
\text { min. }\end{array}$ & $\begin{array}{l}4 \\
7 \\
3\end{array}$ & $\begin{array}{l}2.34 \\
2.56 \\
2.86\end{array}$ & $\begin{array}{r}19.35 \\
13.50 \\
5.69\end{array}$ & $\begin{array}{l}791 \\
838 \\
8.96\end{array}$ & $\begin{array}{r}1320 \\
11.55 \\
9.35\end{array}$ & $\begin{array}{l}8.00 \\
5.88 \\
2.72\end{array}$ & $\begin{array}{l}12.94 \\
11.83 \\
10.36\end{array}$ & $\begin{array}{l}6.93 \\
4.54 \\
1.01\end{array}$ & $\begin{array}{l}6.141 \\
5.032 \\
3.524\end{array}$ & $\begin{array}{l}13.76 \\
28.77 \\
48.79\end{array}$ & $\begin{array}{l}5.00 \\
5.05 \\
5.11\end{array}$ \\
\hline Ferns (brake) . ........ & $\begin{array}{l}\max . \\
\text { med. } \\
\text { min. }\end{array}$ & $\begin{array}{l}5 \\
8 \\
3\end{array}$ & $\begin{array}{l}6.76 \\
6.76 \\
6.76\end{array}$ & $\begin{array}{l}43.13 \\
35.57 \\
22.94\end{array}$ & $\begin{array}{l}4.24 \\
4.04 \\
3.71\end{array}$ & $\begin{array}{r}14.07 \\
12.28 \\
9.30\end{array}$ & $\begin{array}{l}7.76 \\
6.91 \\
5.58\end{array}$ & $\begin{array}{l}0.84 \\
1.64 \\
2.98\end{array}$ & $\begin{array}{l}9.69 \\
8.18 \\
5.68\end{array}$ & $\begin{array}{l}4.85 \\
3.45 \\
1.20\end{array}$ & $\begin{array}{r}6.06 \\
2032 \\
44.10\end{array}$ & $\begin{array}{l}10.01 \\
7.89 \\
3.95\end{array}$ \\
\hline Heath.. & $\begin{array}{l}\max \\
\operatorname{med} \\
\min \end{array}$ & $\begin{array}{r}5 \\
11 \\
6\end{array}$ & $\begin{array}{l}1.91 \\
2.08 \\
2.42\end{array}$ & $\begin{array}{r}20.59 \\
12.89 \\
7.89\end{array}$ & $\begin{array}{l}6.22 \\
6.59 \\
6.84\end{array}$ & $\begin{array}{ll}23 & 79 \\
21.49 \\
16.88\end{array}$ & $\begin{array}{r}11.10 \\
9.35 \\
7.90\end{array}$ & $\begin{array}{l}3.14 \\
4.08 \\
4.80\end{array}$ & $\begin{array}{r}10.00 \\
6.74 \\
4.03\end{array}$ & $\begin{array}{l}3.931 \\
4.09 \\
4.22\end{array}$ & $\begin{array}{l}13.22 \\
29.66 \\
39.99\end{array}$ & $\begin{array}{l}2.67 \\
2.11 \\
2.23\end{array}$ \\
\hline Seaweed... & $\begin{array}{l}\max \\
\operatorname{med} \\
\min \end{array}$ & $\begin{array}{r}9 \\
17 \\
8\end{array}$ & $\begin{array}{l}15.70 \\
14.91 \\
13.91\end{array}$ & & $\begin{array}{l}24.32 \\
22.95 \\
21.26\end{array}$ & $\begin{array}{l}10.65 \\
13.62 \\
15.84\end{array}$ & $\begin{array}{l}6.75 \\
8.15 \\
9.71\end{array}$ & $\begin{array}{l}0.29 \\
0.77 \\
1.32\end{array}$ & $\begin{array}{l}3.21 \\
3.14 \\
3.04\end{array}$ & $\begin{array}{ll}20 & 85 \\
21 & 54 \\
22 & 31\end{array}$ & $\begin{array}{l}0.86 \\
2.07 \\
3.44\end{array}$ & $\begin{array}{l}17.67 \\
17.92 \\
18.19\end{array}$ \\
\hline
\end{tabular}




\title{
STATEMENT ILLUSTRATING BY ANALYSIS
}

\author{
THZ \\ PREDOMINANCE OF POTASH, LIME AND PHOSPHORUS
}

IN THE GREAT MAJURITY OF

VEFETABLES, FRUTTS AND OTHER SUBSTANCES.

\begin{tabular}{|c|c|c|c|c|c|c|c|c|c|c|c|}
\hline \multirow[b]{2}{*}{ DESCRIPTION. } & \multirow{2}{*}{$\left|\begin{array}{c}x \\
0 \\
z \\
z \\
z \\
z \\
z \\
0 \\
0 \\
0 \\
z \\
z\end{array}\right|$} & \multirow[b]{2}{*}{$\frac{\dot{d}}{\stackrel{d}{d}}$} & \multicolumn{9}{|c|}{ IY 100 PARTS OF PUEE ASHES. } \\
\hline & & & 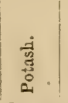 & ஜึં & 音 & 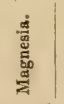 & Б્ & 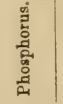 & 葛 & 青 & $\frac{\frac{d}{2}}{\frac{d}{0}}$ \\
\hline agar-cane.. & 5 & 7.70 & 3940 & 8.24 & 2.26 & 3.80 & - & 7.12 & 7.70 & 17.04 & 14.33 \\
\hline nfoin, Clover & 4 & 550 & 28.47 & 3.28 & 36.61 & 649 & 1.15 & 9.94 & 3.40 & 7.28 & 8.83 \\
\hline otton Seed... & 2 & 4.00 & 36.00 & 1.10 & 6.021 & 14.02 & 006 & 3.72 & 4.01 & -1 & 005 \\
\hline "Straw... & 8 & 3.01 & 29.06 & -4 & 42.01 & 8.01 & 0.06 & 18.06 & 3.05 & 3.02 & 0.07 \\
\hline Fibre... $\ldots \ldots \ldots \ldots$ & 1 & 1.0 & 4108 & 6.01 & 12.081 & 11.02 & 2.04 & 6.04 & 402 & 0.03 & 7.08 \\
\hline "Oil-cake, decoriated... & 1 & 6.6 & 47.00 & - & 4.58 & 15.26 & 1.87 & 45.00 & 1.13 & 3.97 & - \\
\hline Flaxseed Oil-cake .......... & 3 & 5.84 & 24.33 & 1.46 & 8.40 & 15.83 & 2.61 & 31.62 & 3.95 & 12.50 & 0.71 \\
\hline Tea Leaves................... & 5 & 548 & 24.67 & 19.42 & 8.87 & 6.18 & 2.39 & 13.28 & 7.00 & 2.82 & 1. 79 \\
\hline Coffee Bean.............. & 9 & 3.19 & 62.47 & 1.64 & 6.29 & 9.69 & 0.65 & 13.29 & 3.80 & 0.54 & 0.91 \\
\hline Apples, . fresh fruit....... & 1 & 1.41 & 35.68 & 26.09 & 403 & 8.75 & 1.40 & 13.59 & 6.09 & 4.32 & - \\
\hline Pears, $\quad$ "6 $\quad 66 \ldots$ & 1 & 1.97 & 54.69 & 8.53 & 7.98 & 5.23 & 1.04 & 15.20 & 5.69 & 1.49 & \\
\hline Cherries, & 1 & 2.20 & 51.85 & 219 & 7.47 & 5.46 & 1.98 & 15.97 & 5.09 & 9.04 & 1.85 \\
\hline Plums, & 1 & 1.82 & 59.21 & 0.54 & 10.04 & 5.46 & 3.20 & 15.10 & 3.83 & 2.36 & \\
\hline Gooseberries, & 1 & 8.39 & 38.65 & 9.92 & 1220 & 5.85 & 4.56 & $19.6 \mathrm{~S}$ & 5.89 & 2.58 & 0.75 \\
\hline Strawberies, & 1 & 3.40 & 21.07 & 28.43 & 14.21 & - & 5.89 & 13.82 & 3.15 & 12.05 & 1.69 \\
\hline $\begin{array}{c}\text { Meat, } \\
6 \\
\text { Veef }\end{array}$ & 2 & 7.60 & $48.91 i$ & - & 0.91 & 2.30 & 0.82 & 36.08 & 3.84 & 2.47 & 6.04 \\
\hline 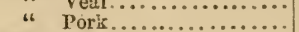 & $\frac{1}{1}$ & 0.20 & 34.40 & 7.26 & 1.99 & 1.45 & 0.27 & 48.18 & - & 0.81 & 6.43 \\
\hline 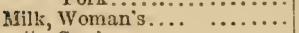 & 1 & 2.00 & 38.08 & 5.69 & $\begin{aligned} 0.53 \\
18.78\end{aligned}$ & $\begin{array}{l}4.85 \\
0.87\end{array}$ & 0.11 & 19.10 & 2.64 & - & 19.06 \\
\hline 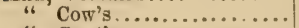 & 4 & 1.75 & 29.77 & 8.60 & 17.81 & 1.90 & 0.33 & 29.13 & 1.13 & 0.09 & 14.37 \\
\hline "Goat's .............. & 1 & - & 43.62 & 9.14 & 4. 59 & 2.42 & - & 14.17 & 2.05 & - & 31.05 \\
\hline Blood, Human ............. & 2 & - & 11.35 & 36.10 & 1.87 & 1.27 & 8.76 & 11.20 & 1.66 & -1 & 84.69 \\
\hline IIen's Egg, the Albumen.... . & $\delta$ & 4.36 & $31 \quad 41$ & 26.72 & 315 & 356 & 0.62 & 4.27 & 1.50 & 2.31 & 32.82 \\
\hline i6 66 "6 Yolk..... & 3 & 3.08 & 3. 8.93 & 5.12 & 12.21 & 2.07 & 1.45 & 6953 & - & 0.55 & $1-$ \\
\hline Cabbage, white......... & 4 & 13.92 & 39.55 & 5.41 & 19.58 & 3.81 & 1.00 & 1673 & 14.81 & 1.32 & 7.46 \\
\hline 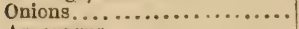 & 1 & - & 43.00 & 1.79 & 28.77 & 4.01 & - & 19.67 & 5.90 & 0.28 & 2. 15 \\
\hline 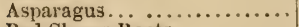 & 1 & 5.30 & 51.71 & - & 21.33 & -7 & 0.31 & 12.36 & 4.49 & 3.74 & 784 \\
\hline Red Clover Roots......... & - & 8.41 & 10.42 & 7.17 & 17.45 & อ.71 & 4.23 & 10.92 & 6.85 & 36.25 & 1.30 \\
\hline 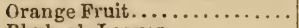 & - & 8.40 & 38.72 & 7. 64 & 22.99 & 6.55 & 0.92 & 14.99 & 2.25 & 5.24 & - \\
\hline Rhubarb Leaves.............. & |- & 8.72 & 14.47 & 81.77 & 3.95 & 5.59 & 1.28 & 31.14 & 9.52 & 2.23 & - \\
\hline
\end{tabular}




\title{
A N A L Y S IS
}

of $\mathrm{TrR}$

\section{COMPARATIVE QUANTITIES OF POTASH, LIME, PHOS- PHORIC ACID, AND NITROGEN}

\author{
In an Average Crop of the Principal Agricultural Productions \\ of Germany.
}

The subjoined analysis was prepared by Count Von Lippe-Weihenfeld, and shows the main ingredients of which average crops of the leading agricultural products in Germany are composed.

When it is desired to double or treble the crops, it is, therefore, only needful to add, in a proportionate degree, to these four articles, as it is shown they are the dominating ingredients in the composition of the various crops mentioned.

\section{ANALYSIS.}

\begin{tabular}{|c|c|c|c|c|c|c|}
\hline \multicolumn{3}{|c|}{$\begin{array}{l}\text { Average Crop per Acre. } \\
\text { Bushels. }\end{array}$} & $\begin{array}{c}\text { Potash. } \\
\text { Pounds, } \\
41\end{array}$ & $\begin{array}{l}\text { Lime. } \\
\text { Pounds. } \\
55\end{array}$ & $\begin{array}{l}\text { Phos. Acid. } \\
\text { Pounds. } \\
33\end{array}$ & $\begin{array}{l}\text { Nitrogen. } \\
\text { Pounds. } \\
58\end{array}$ \\
\hline Wheat..... & 32 & & 31 & 11 & 26 & ธ5 \\
\hline Potatoes.... & 110 & & 82 & 12 & 27 & 53 \\
\hline Oats ...... & 54 & & 37 & 14 & 17 & 58 \\
\hline Vetches ... & 24,800 & U. S. lbs. & 158 & 18 & 48 & 115 \\
\hline Rye ....... & 32 & & 43 & 13 & 25 & 45 \\
\hline Sugar Beets & 40,000 & $\$ 6$ & 206 & 40 & 39 & 105 \\
\hline Barley.... & 38 & & 24 & 9 & 17 & 38 \\
\hline Red Clover. & 42,000 & sc & 146 & 161 & 41 & 168 \\
\hline & & & & & $(57)$ & \\
\hline
\end{tabular}


The foregoing table is calculated for the surface of a $U$. S. acre, from good average crops, as generally produced in Germany, for the express purpose of showing the amount of the four most important ingredients contained in good average crops-viz., potash, lime, phosphorous, and nitrogen. Their dominating power over the second group of inorganic matters and gases, predisposes them for the assimilation of the plants, and therefore, in well-prepared soils, we may be nearly certain that, in doubling or trebling these four ingredients, the crops will be doubled or trebled. This has been proved by_a number of trials which have taken place. 


\section{WHY AMERICAN AGRICULTURISTS OBJECT TO CHEMICAL FERTLLIZERS.}

It must be admitted that very many intelligent farmers have great objections to the use of chemical fertilizers, on the ground that they are not found beneficial to the extent that might be expected; and in many cases they have had very good reasons for the opinions they have formed. The explanation, however, is that the proper standard of quality has not been maintained by American manufacturers, and hence the failure of the manures to produce the desired results. I have no hesitation in stating this to be the case, not only as the result of my own experience, but on the authority of two eminent gentlemen, well known amongst agriculturists-Mr. James Bennett Chynoweth and Dr. William H. Bruckner-in whose "Farmers' and Planters' Guide," published in 1871, a series of analyses are given (which have never been disproved), showing that the fertilizers of American manufacture are not of the quality necessary to produce satisfactory results. This will probably continue to be the case until a law is passed fixing a standard of quality, which all manufacturers shall be required. strictly to obsepve. In Europe such a law was also found necessary, and is now carried out under a system of governmental inspection. By this means the quality can be kept up, and the manures will be found fully satisfactory in America, as they have been proved to be in England, France and Germany. 
The manufacture of these fertilizers is every day becoming of greater importance. In consideration of our exhaustive system of cultivation, more especially in the Southern States, and that farm-yard manure is not produced in the same abundance as in European countries, an adequate supply of chemical fertilizers of the best quality becomes absolutely necessary. It will not be advisable to depend for this supply upon importation solely, as already the foreign producers find great demand for these manures in their own immediate surroundings; so that I think it will be readily seen as most desirable and beneficial to have the manufacture of chemical fertilizers carried on here under such regulations and supervision. as I have hinted at. It will also be most advantageous to make the raw materials necessary for the manufacture of fertilizers free of import duty, so that there may be every opportunity for home producers to compete with importers as to price and quality.

If such legislation as I have suggested cannot be readily obtained, the next best plan would be for Granges and farmers' societies to buy up the materials wholesale, and mix for themselves as the manures were needed; by this means a better quality of manure would be obtainable. 


\section{APPROXIMATE EXHAUSTIVE TIME TABLE}

Of different kinds of Manures and Fertilizers, showing their state of Exhaustion, or Assimilation, in one, two or three years' time, as proved by a number of Experiments made for the purpose of investigating the subject.

BY COUNT VON LIPPE-WEIHENFELD.

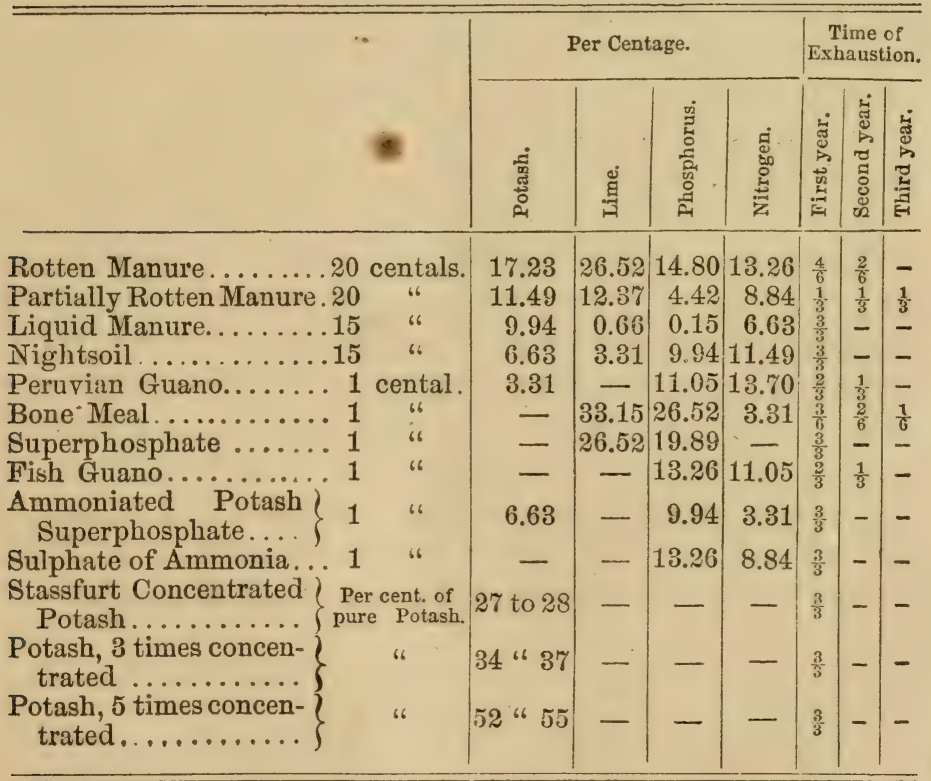




\section{STASSFURT POTASH SALTS}

CONSIST OF

Muriate of Potash.................. 80 per cent.

Sulphate of Potash................. 90 per cent.

They are used as special manures in connection with stable manure, and are rarely applied in larger quantities than about $200 \mathrm{lbs}$. of the higher grades, 300 to $400 \mathrm{lbs}$. of the lower grades per acre. In case they have to be applied as top-dressing, for instance, upon meadows, etc., they have to be mixed with at least three to four times their volume of soil, compost, etc. They are usually applied together with guano, superphosphate of lipne, ground bone, etc., (ir are incorporated with barn-yard manure. The best results regarding the same crops have been noticed upon a loamy soil, less favorable upon a stiff, wet, clayey, or marshy soil, or upon sandy soil without retentive subsoil. When the Stassfurt potash salts were first introduced, their true ralue was greatly underestimated on account of the potash being in its rough state, and mixed with other foreign article; such as magnesia and common salt. The proportions of ingredients given above are recommended as best suited for agricultural purposes. I do not recommend the description known as kinate, as that has not generally given satisfaction. 


\section{ARTIFICIAL PLASTER, OR SULPHATE OF LIMIE.}

Fine pulverized Sulphur............... 10 pounds. Fine pulverized fresh-burned Lime (not slacked)... 100 pounds.

These to be mixed together as carefully as possible. In a few days the pale yellow color of the mixture will change to white, and then through the action of the oxygen is formed sulphate of lime. The quantities stated above produce 133 pounds of plaster, in a mixture of 180 pounds total weight. Plaster is exceedingly useful, not only for the soil, but in fermenting the manure, and sprinkling freely in stables, its action being to fix the ammonia. As ammonia is very volatile, it is fixed effectually by the application of plaster. Probably this was the object of Mr. Ville in using such a large quantity of plaster in his artificial manures. 


\section{FERMENTATION OF MANURES AND NITRI- FICATION OF THE SOIL.}

What is the most advantageous mode of fermenting manure? and when are the best times for the application?

These are questions continually asked in the agricultural papers. Messrs. Deherain and Thenard give the best answer in their trials with nitrated glucose, which holds about the same ingredients as a well rotten manure. If a rich moist manure-heap is kept in a medium state of temperature, not only no ammonia is lost, but 15 to 21 per cent. of the atmospheric nitrogen is absorbed by the manure. If alkalies, phosphates, carbonate and sulphate of lime are added, the greater will be the efficacy of the absorbing power of the manure; but in all cases where a quick return is not wanted, the sooner the fresh manure can be mixed with the soil, the more nitrates will be formed, and the action of the fermenting power of the manure on the insoluble inorganic matters in the soil will be the more effective. It is proved to-day that nitrogen and the inorganic ingredients are the predominating elements in vegetable life; and it is not less clearly proved, that though we can produce very large crops with artificially-rendered soluble nitrogenized mineral matters, the most fertile cultivated soils, which produce large crops without manure, are eminently rich in both organic and inorganic matters in a soluble state. This confirms the impressions formed from soil analyses, where 
it was found in two soils equally rich in mineral matters, that the one contained a good deal of humus or organic matter, and was very fertile, while the second, which was devoid of organic matter, produced a good crop only when heavily manured, the reason being that through the action of the humus, the first soil held soluble inorganic matter, while in the latter it was insoluble.

The best time and mode for manuring is in summer, on a plowed soil-the manure well mixed with the surface, because it is proved that the best conditions for the process of nitrification are a warm temperature with a moist soil, and a mellow fermenting surface. These are just the conditions in the tropical countries (where the moisture is supplied by heavy night dews), under which all the commercial nitrates are prodnced; in these countries the nitrification of the soil goes on the whole year-never ceasing; whereas, in the temperate countries, there is little or no nitrification in the winter-it ceases altogether for a longer or shorter time. Thus science explains the well-proved practical fact (which has long been extensively known and appreciated on the continent of Europe), that manure should be mixed in summer with a well-plowed soil, stirring it several times, by this means producing a double action-the nitrifying action of the atmospheric nitrogen combining with the decomposition of the carbonaceous matter of the manure. This action and reaction has a dissolving effect on the insoluble matters in the soil, and helps to render them soluble; the greater the amount of the soluble nitrifiable mineral salts present, and the higher the temperature of the summer, the greater will be the richness of the nitrates produced by the soil. These are facts which cannot be too often repeated to farmers. 


\section{DEEP AND SHALLOW PLOWING.}

Deep plowing is always a great benefit in rich alluvial soils, where the subsoil is permeable and of an even quality with the surface soil, and also in nearly all the soils which contain a great quantity of organic and inorganic matter. In such soils deep plowing and a continual stirring is stfficient to keep them fertile tor a long time; because, through the decomposing action of the air on the organic matters, nitrification takes place, and at the same time dissolves the inorganic matters, and renders them capable of being assimilated by the plant; but in all other cases, with thin surface soils and defective, poor or impervious subsoils, it would be poor economy to mix the surface soil with a part of the subsoil (except gradually), because, without a continual manuring, the damaging effect would be felt for a long time. Such improvements are of little value, except where the subsoil holds some organic or inorganic matters; but in exceptional cases, as in turfy soils, where the surface soil consists of too much organic matter, the subsoil must be brought up, no matter what kind of soil; but the burning of such a soil, as is generally done in Europe, would convert it when drained into a permanent fertile soil forever. We therefore draw the following

\section{Conclusions:}

(1.) That all zaturally rich soils, holding in a soluble state and in great quantities the inorganic matter needed as plant-food, should always be deeply cultivated.

(2.) That all good deep soils, to which some of the prin- 
cipal inorganic matters have to be added to produce heavy crops, should also be deeply cultivated.

(3.) In all soils of medium quality, where the subsoil is poorer in inorganic matters and in an insoluble state, as is generally the case, deep plowing wonld not be profitable, except where continual manuring could take place, which would ferment the soil, and render the inorganic matters soluble.

(4.) It is now proved that a great deal of heary clay soil, very rich in inorganic matters, but without organic mattur's, is nearly unproductive, unless heavily manured, so as to render the inorganic matters soluble, because the organic matters act as a dissolvent and nitrifier; and, therefore, in the artificial nitre beds in hot climates, lime and organic matters are mixed with clay soil for the production of nitrates of potash.

(5.) In a greater part of the prairie soils of the West, there is too much organic matter in proportion to the inorganic; and application should be made of lime and alkalies for the burning and decomposition of the organic matters, as thereby the nitrogen of the air enters into combination with the carbonaceous alkaline ingredients to form nitrates.

In addition, I would say that the most approved principle in cultivation is to keep all the manuring matters, organic or inorganic, mixed with the surface soil, as it is a settled fact that decomposing organic matter in the presence of inorganic matter, and in contact with the air, leads to the formation of the greater amount of nitrates, particularly in the summer season. When mineral salts capable of nitrification are present, the higher the temperature, the greater will be the richness of the nitrates produced by the soil.

These are well established facts, which cannot be too often repeated and kept under the notice of the farmer. 


\section{WHY WET LANDS SHOULD BE PLOWED IN BEDS.}

Very frequently farmers with large tracts of low-lying flat lands suffer greatly from the effects of heavy rains and the melting of snow; and many persons argue that the only remedy in their case is the carrying out of a perfect system of drainage.

To drain land in the manner advocated would, in many instances-more especially in the Western States-be a very expensive, if not impracticable, process. I would advise in all impermeable subsoils that the land should be plowed in beds, of from four to six yards wide; and this plan, which has long been in operation in various parts of the continent of Europe, would be found to answer very much the same purpose as the more expensive drainage system.

Plowing in beds will, to almost the same extent as drainage, render highly productive land that would otherwise be unprofitable. One of the first necessities in the cultivation of land is to get it well drained, as wet subsoils will never nitrify to the extent necessary for rendering them productive, and hence the killing of winter wheats, of which Western farmers so often complain. But draining in many cases presents such insurmountable difficulties, that farmers will not attempt it, unless it can be done by some such simple and cheap process as that I have suggested. 


\section{AGRICULTURAL TRIALS MADE AT PROSKAU, GERMANY.}

A series of agricultural trials were made in 1869 , by the professors of the Trial School at Proskau, Germany. The following were among the results arrived at as to the beneficial effects upon the ground of the growth of certain crops :

\begin{tabular}{|c|c|c|c|c|c|c|}
\hline \multirow{3}{*}{ · } & \multicolumn{3}{|c|}{ STUBBLE AND ROOTS AFTER } & \multicolumn{3}{|c|}{ HARVEST, 10 INCIES DEEP. } \\
\hline & $\begin{array}{c}\text { Total Dry } \\
\text { Substances } \\
\text { per English } \\
\text { Acre. }\end{array}$ & $\begin{array}{l}\text { Organic } \\
\text { Matter. }\end{array}$ & Ashes. & Nitrogen. & Potash. & $\begin{array}{l}\text { Phosphoric } \\
\text { Acid. }\end{array}$ \\
\hline & No. of lbs. & No. of lbs. & No. of lbs. & No. of lbs. & No. of lbs. & No. of lbs. \\
\hline Lucerne. . . . . . . & 9,702 & 8,498 & 1,204 & 137 & 37 & 40 \\
\hline Red Clover..... & 8,953 & 7,026 & 1,927 & 193 & 82 & 75 \\
\hline Sanfoin ....... & 5,952 & 4,925 & 1,027 & 124 & 48 & 30 \\
\hline
\end{tabular}

In connection with these trials it is proper to draw attention to the disadrantages of climate for the growth of many plants, from which the American farmer suffers more, in comparison, than European agriculturists. The latter also, in addition to their extensive cultivation of clovers, roots and tubers, vetches and forage plants, possess the great benefits arising from the natural and artificially irrigated meadows, which produce large crops without manure and with very little labor. In the mountainons parts of Europe agriculture could hardly exist without these meadows, so important is their influence in increasing the productiveness of the land. 
There is an erroneous idea that irrigation has only a moistening and dissolving effect-instead of this being the case, all the water derived from cultivated soils holds in a soluble state all the ingredients necessary for vegetation, and hence the productiveness of this meadow land, to which I have referred, without the application of manure.

It will be observed that, in the above analysis, red clover occupies the medium place in the beneficial influence which its cultivation produces upon the soil. It is the only one of the three that has at present been at all extensively cultivated in America. Red clover cannot be too largely cultivated by the American farmer, and it will always be found of very great service in preparing the soil for other crops.

Lucerne is considered the best plant for soiling in Enrope, and I recommend it as the best for introduction here. It has not at present received any extensive notice; but there is no reason why it should not be used to a large extent. It needs a dry, rich land, as the quicker its growth the better is its quality.

Sanfoin is the best feed for cows, improving the quality and increasing the quantity of milk more than anything else. It requires a dry soil, either drained, plowed in beds, or a naturally dry land. Sanfoin does not require quite such rich land as lucerne.

The cultivation of each of these should receive the careful attention of all farmers' clubs, and it would be most desirable that prizes should be offered for competition, so that the best conditions for their growth might be definitely ascertained, and their advantages become better known.

In consideration of the importance of irrigation, I would also recommend that prizes should be offered, for general competition, with a view of obtaining the best and cheapest plans by which American farmers can be enabled to have all the information on that subject at their disposal. 


\section{GRASSES.}

I reconmend for cultivation the quick-growing natural grasses: (1) wild rice (zizania aquatica); (2) orchard-grass (dactylis glomerata), already grown extensively in the Southern States with great success; (3) tall oat-grass (arrhenatherum avenaceum). Each of these are excellent hay and pasture grasses, and even for green manuring. Their yield is nearly double that of timothy and red-top grasses; and they are very early and late growing grasses.

I would particularly recommend the sowing of other large-leafed and deep-rooted grasses, for the special purpose of green manuring, as these can be raised on wet and poor land, where clover would not succeed. This was the plan advocated by Charles L. Flint, the well-known Secretary of the Massachusetts State Board of Agriculture, in his work on "Grasses and Forage Plants," published in 1859, and if his advice had been more generally followed, beneficial results would have been seen therefrom:

On this point, as well as the cultivation of clovers and irrigation, I would again suggest that prizes should be offered by all farmers' clubs, so as to promote trials by farmers, and thus bring about a more general appreciation of the importance of selecting the right kinds of grasses. 


\section{POTATO TRIALS WITH TURF AND INOR- GANIC MATTER.}

MFado by Ph. Zoeller and Beichenbach, and published in Henneberg's "Journal of Agriculture" for 1866.

These trials were made in wooden boxes, each one filled with 720 litres of turf, equal to 760 quarts; and the turf contained, in each box, 25 kilogrammes (equal to 55 quarts) of ashes. In 100 parts of dry turf there were contained:

BOX Na. 1.-TURF, WITH ASHES.

Potash. Soda. Lime. Magnesia. Phosph. Sulph. Chlorine. Silica. Nitrog. Amm. $\begin{array}{llllllllll}0,110 & 0,(123 & 1,108 & 0,095 & 0,220 & 0,121 & 0,039 & 2,245 & 2,460 & 0,183\end{array}$ BOX No. 2, IN ADDITION TO ABOVE:

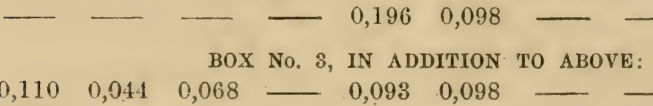

At the end of September the tops began to dry; the crop was gathered the $3 d$ of October, and the crop in each box was as follows.

\section{AIR-DRIED CROP.}

$\begin{array}{llcc}\text { Potatoes } \ldots \ldots \ldots \ldots \ldots \ldots \ldots \ldots \ldots \ldots & \begin{array}{c}\text { No. 1. } \\ \text { Grammes. } \\ 2,520\end{array} & \begin{array}{c}\text { No. 2. } \\ \text { Grammes. } \\ 3,062\end{array} & \begin{array}{c}\text { No. } 8 . \\ \text { Grammes. } \\ 7,201\end{array} \\ \text { Tops } \ldots \ldots \ldots \ldots \ldots \ldots & 1,837 & 3,535 & 2,870\end{array}$

These crops, calculated on the surface of one quarter of a hectare, equal to five-eighths of an acre, are as follows:

\begin{tabular}{|c|c|c|c|}
\hline$\ldots \ldots \ldots \ldots$ & $\begin{array}{l}\text { No. 1. } \\
\text { Pounds. } \\
7,000\end{array}$ & $\begin{array}{c}\text { No. } 2 . \\
\text { Pounds. } \\
8,506\end{array}$ & $\begin{array}{l}\text { No. } 3 . \\
\text { Pounds. } \\
20,003\end{array}$ \\
\hline & 5,013 & 9,320 & 7,972 \\
\hline
\end{tabular}


These potatoes were all sound at the digging, but six weeks after Nos. 1 and 2 began to rot, while No. 3 remained sound until spring time.

These experiments confirmed the belief which has been ndranced, that potash and the mineral salts not only produce a healthy crop, but by judicious application are capable of doubling or even trebling the crop, as No. 3 gave 530 bushels to the acre.

\section{Potato Trials.}

By T. H. Anderson, published in the "Journal of the Highland Society," in 1862.

Two kinds of potatoes-Dalmahoy and Regent-were raised on a rich and heavy clay soil, and the conditions under which the eight distinct trials were made were as follows :

(a.) Dalmahoy: 'Trial No. 1, without manure; No. 3, superphosphate of lime, 5 cwt., and guano, 3 cwt. ; No. 5, farm-yard manure, 25 tons; No. 7 , farm yard manure, 35 tons.

(b.) Regents: Trial No. 2, without manure; No. 4, superphosphate of lime, 5 cwt., and guano, 3 cwt.; No. 6, farm-yard manure, 25 tons; No. 8 , farm-yard manure, 35 tons.

At the gathering of the crops, October 21st, the average weight of a single plant, in grains, was as follows:

$$
\text { DESCRIPTION OF POTATO. }
$$

(a.) Dalmahoy.

$-\frac{1}{3}-\frac{7}{5}$

Grains. Grains, Grains. Grains.

Sound Potatoes. . $\quad 6,683 \quad 12,383 \quad 12,200 \quad 10,550$

Sickly " " . $3,133 \quad 2,900 \quad 5,016 \quad 6,416$

$\begin{array}{llllll}\text { Tops } \quad \ldots & 1,816 & 1,640 & 1,750 & 1,566\end{array}$ (b.) Regent.

$\overbrace{24}^{4} \overbrace{8}$

Grains, Grains. Grains. Grains. $6,0148,1338,0147,616$ $2,700 \quad 7,916 \quad 4,433 \quad 3,941$

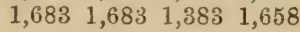

The result of these experiments confirms the general belief that no healthy crops of potatoes can be raised in heavy, rich soils, no matter what manure may be applied to the soil. 


\section{TRIALS ON SUGAR-BEETS WITH TURF AND FERTILIZERS.}

Made by Ph. Zoeller, and published in Henneberg's "Journal of Agriculture" for 1866.

These trials were made.in wooden boxes, and powdered turf was used as soil. The air-dried turf contained 20.83 per cent. of water, 7.60 of ashes, and 3.11 of nitrogen. The ashes contained, in 100 parts:

Potash. Soda. Lime. Magne. Phosph. Sulph. Chlor. Alumin. Silicon. Acid. Sand, \&c. $\begin{array}{llllllllll}0,924.1,928 & 31,470 & 2,660 & 0,960 & 0,058 & 0,000 & 13,250 & 7,910 & 0,000 & 38,242\end{array}$

There were six trial-boxes, and each box held 600 litres of turf, equal to 632 quarts.

No. 1 contained only turf.

No. 2. The same turf, with 4,389 grammes of potash, 366 grammes of ammonia, and 246 grammes of phösphoric acid.

No. 3 . The same turf, with 366 grammes of ammonia, 246 grammes of phosphoric acid.

No. 4. The same turf, with 366 grammes ammonia, 246 grammes of phosphoric acid, 438 grammes of potash, and 250 grammes of common salt.

No. 5. 'ithe same turf, with 438 grammes of potash and phosphoric acid.

No. 6. The same turf, with 438 grammes of potash, 250 grammes of common salt, and 246 grammes of phosphoric acid. 
Besides, there was added to each box (No. 1 excepted), 100 grammes of magnesia. As the No. 2 was shaded by a tree, it cannot well be compared with the others. In each box there were nine beets grown, which gave, on the 4 th of November, the following results:

$\begin{array}{crrrrrr} & \begin{array}{c}\text { No. 1. } \\ \text { Gram. }\end{array} & \text { No. 2. } & \text { No. 3. } & \text { No. 4. } & \text { No. 5. } & \text { No. 6. } \\ \text { Gram. } & \text { Gram. } & \text { Gram. } & \text { Gram. } \\ \text { Air-dried Roots... } & 1,552 & 3,935 & 3,322 & 8,518 & 7,691 & 7,723 \\ \text { " Leaves. } & 2,717 & 6,625 & 7,583 & 7,901 & 5,706 & 8,697 \\ \begin{array}{c}\text { Per cent. of Sugar } \\ \text { in the Roots... }\end{array} & 7.46 & 5.86 & 8.34 & 6.50 & 7.32 & 4.42\end{array}$

The results of the six boxes are calculated on the surface of one quarter of a hectare to $\frac{5}{8}$ of an acre:

\begin{tabular}{|c|c|c|c|c|c|c|}
\hline & $\begin{array}{l}\text { No. 1. } \\
\text { Pounds. } \\
7,964\end{array}$ & $\begin{array}{l}\text { No. } 2 . \\
\text { Pounds. } \\
20,192\end{array}$ & $\begin{array}{l}\text { No. 3. } \\
\text { Pounds. } \\
17,047\end{array}$ & $\begin{array}{l}\text { No 4. } \\
\text { Pounds. } \\
43,695\end{array}$ & $\begin{array}{l}\text { No. } 5 \text {. } \\
\text { Pounds. } \\
39,4666\end{array}$ & $\begin{array}{l}\text { No. } 6 . \\
\text { Pounds. } \\
39,610\end{array}$ \\
\hline & & 33,996 & 38,912 & 40,544 & 29,280 & 44,6 \\
\hline
\end{tabular}

The general conclusion to be dratrn from these trials is, that ammonia and chlorine develop the blade more than the roots.

Potash is needed for the production of nearly every crop, but particularly for potatoes and sugar-beets. In the case of potatoes, it develops the starch, and improves both quantity and quality; while, in sugar-beets, it increases the percentage of saccharine matter. Farm-yard manure is damaging for both of these; it will injure the taste of potatoes and produce rot, and if used with sngar-bests, the quality will deteriorate, in consequence of foreign matters destructive of the saccharine qualities being thereby introduced.

Large potatoes should always be selected for the purposes of seed; cut the tops (not too thin) between the fall and spring, and keep dry until planting time.

It is proved that nearly all seeds are the best and soundest when they contain the largest quantity of inorganic matters. 


\section{METHOD FOR DETERMINING THE QUANTITY OF STARCH IN POTATOES,}

As practiced by the Slarch Manufacturers in Germany. .

The process is as follows:

Take seren large glasses, and put in each one half a pound of water, then add to the first glass 480 grains of well-roasted common salt; to second glass, 540 grains; to third, 600 grains ; to fourth, 660 grains; to fifth, 720 grains ; to sixth, 780 grains; and to seventh, 840 grains. If the salt is all dissolved, then put the potato that is to be tried in No. 7 ; if it swims, put it into No. 6, and so on, until the glass is found where it sinks, and the water is, therefore, lighter than the potato. Note the number, and then continue trying six to eight of the same kind of potatoes, marking the number of each potato, and the glass in which it sinks. Then add all these numbers together, and the average, or mean, will indicate the approximate quantity of starch contained in any kind of potato tried, as is shown by the annexed table:

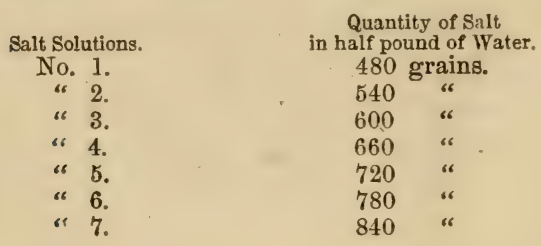

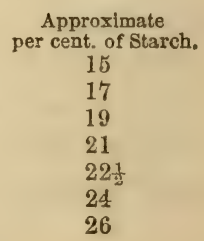


If the potato swims in No. 1 , then it has less than 15 per cent. of starch; and if it sinks in No. 7, then it has more than 26 per cent. Though these trials give only approximate results, it is proved that different sorts of potatoes may vary between 14 and 27 per cent. in starch. 'The fact that any body can at any time make these experiments, is of the greatest importance for farmers, starch manufacturers and dealers to know, as the percentage of starch in a potato determines its quality. 


\section{A D D RES}

\section{OF \\ BARON JUSTUS VON LIEBIG \\ TO $2 \mathrm{H}$}

ACADENY OF SCIENCES AT MUNICH.

During last year, experiments relative to the establishment of laws on the nutrition of plants have been pursued by the Institute of Physiology of Plants, under direction of Professor Nægali and $D_{1}$. Zoller. Their experiments were made upon the potato, as the plant most important for food after the cereals (corn). Three fields were prepared for experimenting on; the first composed of mold (pulverized peat) from the turf-beds of Kolb; the second, of the same soil, mixed with ammoniacal salts, as the principal agent in animal manure; and the third, of the same mold, to which was added the fixed elements constituting the ashes of the potato. An equal number of tubers of the same kind were planted in each field.

Without detailing the various stages of development, I will confine myself to calling attention to the differences between the crops. That from the land manured with the ammoniacal salts was 20 per cent. larger than that of the field No.1, which had received no addition; but that of the third field (which had the manure of phosphate of lime and of potash) was nearly triple. The proportion of the three crops ran thus: 100, 120 and 285 . The quantity of potatoes gathered on field No. 3, to which had been furnished 
the elements composing the ashes of the plant, was 282 hundred-weight to each workman-nearly double the crop given by the best arable land.

The results, so very different, of the three experiments can only be attributed to the difierent composition of the land of the three fields, all other conditions being identically alike. In the two first, a number of circumstances were to produce in the subterranean organs as many organic substances (or tubercles) as in the third; or rather, which is the same, to take from the air a sum equal to their constituent elements.

These indications, although important enough in themselves, are, nevertheless, not the most remarkable results of the experiments ; for here is the precious information they give us: All the potatoes gathered from the two fields which, by the composition of their soil, presented the elements necessary for the development of the plants only in insuficient quantity, or in false proportions, were the prey of disease. From the straws, which became black, decomposition spread, and at the end of a few weeks had thoroughly gone through the interior. In opposition, the potatoes in the third field, manured with the fixed elements of the plants, are now (Dec. 1st, 1865) perfectly sound: in not one is seen traces of the ravages commonly attributed to the oidium. Hence, from these observations, we see that, undoubtedly, the conditions favorable to the normal development of plants are those which prevent disease, and that, in consequence, the first cause of the disastrous epidemic should be songht in the land. If the land present in sufficient quantity the elements indispensable to organic life, or the growth of the plant, the latter receives the power of opposing resistance great enough to paralyze completely all hurtful influences which can affect it from outside. 


\section{WHLAT TRIALS}

By Messrs. Lawes and Gilbert, in England, between the years 1845 and 1854, showing the Average Crop per acre from Unmanured Land, with the use of Ammonia Salts alone, and of Mineral Manure combined with Ammonia Salts. These trials were continued for twenty consecutive yeurs on the same field, the results being always about the same.

AVERAGE CROP PER ACRE.

Unmanured Land. Pounds.

2856
Ure of Ammonia Salts alone. Pounds. 4,808
Use of Mineral Manure

with Ammonia Salts.

Pounds. 


\section{EFFECT OF VARIOUS KINDS OF MANURE ON OATS AND BARLEY.}

Table showing the comparative quantity of starch and albumen contained in 100 pounds of oats, barley and wheat grown on the same kind of soil, but with different kinds of manure-an equal quantity of manure for each kind of grain :

\begin{tabular}{|c|c|c|c|c|c|c|c|}
\hline \multirow{3}{*}{\multicolumn{2}{|c|}{$\begin{array}{l}\text { DESCRIPTION OF } \\
\text { MANURE. }\end{array}$}} & \multicolumn{2}{|c|}{ BARLEY. } & \multicolumn{2}{|c|}{ OATS. } & \multicolumn{2}{|c|}{ WHEAT. } \\
\hline & & \multicolumn{2}{|c|}{ Percentage of } & \multicolumn{2}{|c|}{ Percentage of } & \multicolumn{2}{|c|}{ Percentage of } \\
\hline & & Starch. & Albumen. & Starch. & Albumen. & Starch. & Albumen, \\
\hline \multirow{3}{*}{\multicolumn{2}{|c|}{$\begin{array}{l}\text { Blood .............. } \\
\text { Poudrette... . . . . . . } \\
\text { Sheep Manure...... }\end{array}$}} & $66 \frac{1}{2}$ & $6 \frac{1}{2}$ & 60 & $5 \frac{1}{2}$ & 41 & 54 \\
\hline & & $66^{2}$ & $6 \frac{1}{2}$ & 60 & 5 & - & - \\
\hline & & $66 \frac{1}{2}$ & $6 \frac{1}{2}$ & 61 & $4 \frac{1}{2}$ & 42 & 33 \\
\hline Horse "6 & $\ldots \ldots$ & 66 & $6 \frac{1}{2}$ & $61 \frac{1}{2}$ & $4 \frac{1}{2}$ & 62 & 14 \\
\hline Cattle & & 69 & $3 \frac{1}{2}$ & 62 & $3 \frac{2}{2}$ & 62 & 12 \\
\hline Green "6 & $\ldots \ldots$ & 69 & 3 & $66 \frac{1}{2}$ & $2 \frac{1}{4}$ & 66 & 10 \\
\hline Without " & $\ldots \ldots$ & $69 \frac{1}{3}$ & 3 & $66 \frac{1}{2}$ & $2 \frac{1}{2}$ & - & - \\
\hline
\end{tabular}

This table shows that very rich nitrogenized manures have little beneficial influence on the grain of oats and barley; and therefore it was an error on the part of Mr. Ville to recommend such a free application of nitrogen in the cultivation of those crops. 


\section{MISCELLANEOUS TOPICS.}

\section{Plow and Cart-horses.}

A question which must yet receive careful attention on the part of American agriculturists is, as to the best method of procuring and retaining a class of useful, solid plow and cart-horses. The mere importation of a good race of horses is not sufficient, unless the type shall be kept pure. In Europe the same difficulty has had to be met; and it has been proved by the experience of the past that the character of horses soon deteriorates if mixed with a breed of a different class. What is greatly needed here is to obtain a class of agricultural horses fitted to the country and to the especial work for which they are intended, and then let the race be kept pure and distinet, introducing, when necessary, oriental horses for giving more vigor and improving the type. I would advise, also, as likely to prove advantageous, the production of a class of larger mules.

\section{Lrve-stock, Feeding, Butter and Cheese Factories, do.}

My advice to Western farmers is, to keep an improved class of live-stock, and to use all their corn for the purposes of feeding, as this will, in the end, be found more profitable, and a large quantity of manure will thus be produced.

Farmers should also combine for the purpose of establishing butter and cheese factories, slaughter and smoke- 
houses; if they do this, I believe they will have the advantage over all the farmers of the world.

\section{Canals for Irrigation and Transportation.}

In another part of this work, I have suggested a method by which farmers who cannot afford the expense of carrying out a system of drainage or irrigation, may promote the fertility of their land by plowing in beds; yet I cannot too strongly enforce the need for irrigation and that the making of canals be more generally attended to. It is only by these means that much of the land can be continued fertile; and the canals made for the purpose of irrigation may afford the means of transportation, as well as refreshing the land during the summer months. This is what England is doing on a very extensive scale in her Indian possessions; and the same idea has commended itself to the large bodies of practical agriculturists assembled in the various Granges recently formed in this country, by whom the question of transportation has been discussed with a view to the discovery of the most practical method of surmounting the difficulties in the way of successful farming in the Western States.

All Seeds for Planting shodld be Imported Free of Duty.

In Russia a special arrangement is made, under government authority and superintendence, for the production of flaxseed exclusively for seeding. It is grown under the most favorable conditions possible, and is raised for the express purpose of exportation. Before leaving the exporters' hands it is packed and officially stamped. The quality is so remarkably good that it produces double the crop of fibre and 
seed as compared with other kinds of seed, and at the same time a crop of superior quality to any other.

The difficulty in the way of this seed being used in America is, that it is very high in price, by reason of the amount of import duty which has to be paid. There onght not to be any duty for the importation of seeds intended solely for the purposes of planting; but the actual fact is, they have to pay higher duty than any other descriptions of seed-just contrary to the practice in the leading European countries. 


\section{CONCLUSION.}

I would draw special attention to a few of the leading points presented in the foregoing pages, my desire being to make the hints I have given as practical and useful as possible to American farmers.

Agreeing, in the main, with the lecture of Mr. Ville, I cannot omit to mention that, in my view, some of the opinions advanced by that gentleman are too extreme and sweeping.

In contrasting the influence of farm-yard manure with chemical fertilizers, for instance, his estimate of the value of the former is not fair or just, as sufficieut importance is not attached to the four inorganic matters found therein.

His statement that the worst soils possess secondary mincrals in abundance is wide of the truth, as that is not the case ; and in one instance the experiments on which his argument is based are contradictory, it being proved in one experiment that the plant did not die when there was no phosphate, while in another place he affirms that it did.

Still, taken as a whole, the lecture is an important aid to the discussion of the question at issue, even though the opinions advanced in favor of the excellences of artiticial manures are a little inclined to be extreme.

The first principle needed to be understood, in order to successful farming, is as to the nature and qualities required to make a soil productive; and the analysis of three kinds of land will throw light upon that point, showing, as it does, that the presence of a great quantity of inorganic matters 
of every kind is absolutely necessary to render a soil thoroughly fertile and productive.

The theory of M. Deherain, as to absorption of atmospheric nitrogen by vegetation, I hold to be correct. The question as to the proportionate quantity of nitrogen drawn by plants direct from the air had certainly never been settled by the experiments of Boussingault, Laws and Gilbert, or the writings of Jeaunel, Thenard, and others; but M. Deherain's experiment is very clear, and his theory may, perhaps, be considered almost conclusive.

The investigations by Mr. Nicholls in East India, and the experiments of M. Bartholomy, as to the passage of gases through the vegetable colloidal membrane, are valuable, as furnishing confirmatory evidence as to the correctness of M. Deherain's theories.

Among agriculturists there has always been a wide difference of opinion upon this important subject-the action of the air in the nitrification of the soil ; and I have, therefore, thought it advisable to bring together in this work the thoughts and arguments of several eminent men, with a view of elucidating the whole question, and showing the present position of the discussion as plainly and clearly as possible.

The analytical tables of Dr. Emile Wolf are, probably, the most complete and authentic of any analyses ever published on the particular question to which they refer, namely, the percentage of ashes found in the principal agricultural crops, and the effects produced by alkalies upon the other inorganic matters; the latter being given with a view of proving that potash, lime, phosphorus and nitrogen are the four dominating ingredients, upon whose presence in the soil depends, in a great measure, the value of the crops produced. 
The analysis by Count Von Lippc-Weihenfeld, showing the four dominating ingredients in an average crop of the leading agricultural products of Germany, confirms the correctness of the calculations of Dr. Wolf, and also of the opinions to which I have given prominence.

I wish to draw marked attention to the importance of using a greater quantity of nitrates in farming operations in this country. More lime and alkalies should be employed, as nitrifiers, in conjunction with organic matters in the shape of green manures; in that way obtaining, to the greatest extent possible, the beneficial effects which follow the natural nitrification of the scil in hot climates. To this end, I have very earnestly recommended to farmers to adopt the cultivation of lucerne, sanfoin and red clover, and also the large-leafed, deep-rooted natural grasses.

In the latter part of this work I have given details of various trials made by eminent agriculturists, for the double purpose of disseminating valuable information on practical questions interesting to all agriculturists, and also with a view of inciting American farmers to make experiments of a similar nature themselves. 


\section{FRENCH KILOGRAMMES}

\section{REDUCED TO UNITED STATES POUNDS.}

\begin{tabular}{|c|c|c|c|c|c|c|c|c|c|}
\hline F. K. & ర. S. P. & r. $\mathrm{E}$. & U. S. P. & F. K. & U. S.P. & g. . & U. S. F. & F. K. & c. S. P. \\
\hline 1 & 2.21 & 20 & 44.20 & 300 & 663 & 3000 & 6630 & 30000 & 66300 \\
\hline 2 & 4.42 & 30 & 66.30 & 400 & 884 & 4000 & 8840 & 40000 & 88400 \\
\hline$\delta$ & 6.63 & 40 & 88.40 & 500 & 1105 & 5000 & 11050 & 50000 & 110500 \\
\hline 4 & 8.84 & ธо & 110.50 & 600 & 1326 & 6000 & 13260 & 60000 & 132600 \\
\hline 5 & 11.05 & 60 & 132.60 & 700 & 1547 & 7000 & 15470 & 70000 & 154700 \\
\hline 6 & 13.26 & 70 & 154.70 & 800 & 1768 & 800 & 17680 & 80000 & 176800 \\
\hline 7 & 15.47 & 80 & 176.80 & 900 & 1989 & 9000 & 19890 & 90000 & 198900 \\
\hline 8 & 17.68 & 90 & 198.90 & 1000 & 2210 & 10000 & 22100 & 100000 & 221000 \\
\hline 9 & 19.89 & 100 & 221.00 & 1100 & 2431 & 11000 & 24310 & 110000 & 24310 \\
\hline 10 & 22.10 & 110 & 243.10 & 1200 & 2652 & 12000 & 26520 & 120000 & 265200 \\
\hline 11 & 24.31 & 120 & 265.20 & 1300 & 2873 & 13000 & 28730 & 130000 & 287300 \\
\hline 12 & 26.52 & 130 & 287.30 & 1400 & 3094 & 14000 & 30940 & 140000 & 309400 \\
\hline 13 & 28.73 & 140 & 309.40 & 1500 & 3315 & 15000 & 33150 & 150000 & 331500 \\
\hline 14 & 30.94 & 150 & 331.50 & 1600 & $3536^{\circ}$ & 16000 & 35360 & 160000 & 353600 \\
\hline 15 & 33.15 & 160 & 353.60 & 1700 & 3757 & 17000 & 37570 & 170000 & 375700 \\
\hline 16 & 35.36 & 170 & 375.70 & 1800 & 3978 & 18000 & 39780 & 180000 & 397800 \\
\hline 17. & 37.57 & 180 & 397.80 & 1900 & 4199 & 19000 & 41990 & 190000 & 419900 \\
\hline 18 & 39.78 & 190 & 419.90 & 2000 & 4420 & 20000 & 44200 & 200000 & 442000 \\
\hline 19 & 41.99 & 200 & 442.00 & & & & & & \\
\hline
\end{tabular}

HEOTARE, EQUAL TO 2/子 ACRES; HECTOLITRE, EQU.1L TO 2 84-100 BUSHELS. 


\section{R E C A P I T U L A T $10 \mathrm{~N}$.}

(1.) It is to-day an established fact that nitrogen, potash, phosphor, and lime, are the four principal ingredients in vegetable life; and farmers should therefore be induced, by all possible means, to produce, naturally and artificially, such articles themselves, so far as practicable.

(2.) That, in Europe, the limestone rubbish of old buildings was lixiviated for the nitrate of potash.

(3.) That clay, holding from two to four per cent. of potash, was mixed with lime, animal and organic matters, as an artificial nitre bed, for the lixiviation of nitrates of potash.

(4.) That a well-mixed compost heap is but an artificial nitre bed.

(5.) That Professor Grandeau, of Nancy, France, proved by dissolving, that soils rich in inorganic matters were not productive, except by copious manuring; but that other soils not richer in inorganic matters, were productive without manuring; the real cause of this being proved to be that the first mentioned soils holding no organic matter, their inorganic matters were in a state of insolubility, whereas the latter soil, holding a great quantity of organic matters, their inorganic matters were more or less soluble. 
(6.) That Boussingault proved that permanently wet land cannot nitrify; that dry air and a dry soil are very slow in coming under nitrifying conditions; but that the best results of nitrification have been a moistening and drying process of the soil, and that he used only lime, magnesia, and a little potash as a nitrifier in his nitrifying trials.

(7.) That Jeaunel proved that soils containing humus and lime produce either nitric or nitrous acid, and that by the moistening and drying of the soil the most nitrates are formed.

(8.) That E. Nicholls, as an analytical chemist in East India, shows how easily the nitrates are formed in the black, humic soil of that hot country; also how the different kinds of acids act and react on each other as dissolvents; thereby Mr. Nicholls shows the absence of nitrates of soda and potash, and that all nitrates at that place were deliquescent nitrates of lime and magnesia, and very easily lost by rain (see page 39 ).

(9.) That in the analysis of Sprengel and Mulder, is it not clearly shown that the large amount of organic matter and acid carbonic produced the great amount of soluble inorganic matter in the lower fertile soils?

(10.) That on the mediocre quality of soil on the continent of Europe, where the three and four years' rotation plan is yet in operation, the fallow land-is all plowed in spring; then the manure is spread broadcast over the soil, then turned by the plow and the harrow during the summer; and so the farmers, witnessing the good effects of such a process, without understanding the dissolving and nitrifying chemical process of the soil. The proof that such soils have not deteriorated is, that potatoes are always planted the second year after the manuring, as a general rule; and if the 
average crop of an acre is under 300 bushels of good, sound potatoes in a good soil, then that year is considered as a bad potato season.

(11.) That, fifty or sixty years ago, on the continent of Europe, the black humus-holding soils, with impervious subsoils, were considered as of little value, as they produced only a bad crop of oats; but after a perfect superficial drainage, in plowing the land in beds, with copious application of lime and manure, they were made to produce the heaviest crops in such land. Therefor'e, the fact that nearly all the plowed land of the continent of Europe is superficially drained in beds, and also that only a small percentage of subsoil drainage is yet executed, proves the satisfactory effects of superficial drainage during centuries, and the advocates of superficial drainage claim :

1st. That the work can De done by the farmer himself, without any expense;

2d. That it can be changed at any time;

3d. That the beds shed the rain water on both sides, without soaking the soil of the soluble matters, and particularly in mellow soils;

4th. That in all clay land, particularly if flat, the soils in beds are less tenacious and lose less of soluble matter's than flat plowed;

5th. The great cost of a subsoil drainage, and the loss if not well executed.

(12.) That J. Ville ignored purposely the fermenting and the nitrifying quality of the stable manure in the soil, in recommending the use of chemical fertilizers exclusively, and the reduction and the fixation of the nitrogenized matters in his mixtures of the chemical manures (by the 
action of the sulphuric acid in the plaster) was done under the pretence for the supposed greater solubility of the lime in the plaster; but the sulphate of lime or plaster is not so valuable, on account of his 32 per cent. of lime, as for his 46 per cent. of sulphuric acid, as a fixing medium of nitrogen and ammonia, and it cannot be used too copiously by farmers in manures and in the stable to prevent any loss of ammonia.

(13.) That the richest natural and artificial nitre beds are those holding the greatest amount of inorganic and organic matters in a decomposed state; but that subsoils, rich in insoluble inorganic matters, were unproductive till a copious broadcast of stable manuring had taken place; that in mixing clay, lime, organic or animal matters together, inorganic matters get soluble, and nitrates are formed; that in a compost heap the same thing takes place, and therefore, in a well-manured and cultivated soil, of necessity the same takes place.

In consideration of all this, is it a wonder that such a great quantity of American soil has been exhausted? But a partially plowed, overcropped, and never manured soil may not, in my opinion, be exhausted, but is only starved out of its soluble inorganic matters, for the want of a dissolving power being applied to it in time to prevent all this. Money and time expended upon such soil would have the effect of 'restoring it to its primitive fertility. Therefore, I advise that you do not compost your manure with soil, but compost all your plowed land with your manure-with green manure, and with lime-to convert it all into an "artificial nitre bed," as Boussingault calls it. As the natural production of your stable manure will not be sufficient, use fertilizers in the beginning, till you have 
doubled or trebled your crops, and you will thus show that farming pays, because the cost of producing a minimum crop is about the same as the cost of a maximum crop.

Many people speak of inorganic matter, or of the great amount of nitrogen in the air, as if those ingredients could be eaten by the plants with spoons. Carbonate of lime and magnesia are not only valuable plant food, and, as decomposers of organic, and inorganic matter; but they are as great nitrifiers as the alkalies, though their nitrates are of a more deliquescent nature. Neither lime nor alkalies should, however, be used in a caustic state to any manure or composition of manures where actual ammonia or nitrates are present, because there would be loss of ammonia and nitrogen; and as for lime in the soil requiring a great deal of water and time for its dissolving action and reaction on the soil, the fact is that lime should never be applied immediately to plowed land, that has to be seeded immediately.

It is only by closely studying nature's laws that any one can succeed in discovering their secrets.

After great consideration of the controversy as to the proper estimated value of the different kinds of guano, as shown by various analyses, my conclusion is that the Peruvian guano has proved always the best-it is the highest in value, especially if it be obtained from the first hands. For a reliable estimate of the value of Peruvian guano, the reader is referred to the analytical table of Count Von Lippe-Wiehenfeld, given on page 61 . 


\section{H. J. BAKER \& BRO.,}

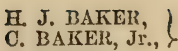

F. WILEY.

215 Pearl St., NEW YORT, IMPORTERS AND DEALENS IN

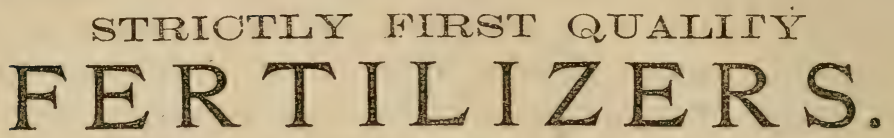

We Compound Special Fertilizers for Parficular Crops.

GEORGE B. FORRESTER, Manager of this Department.

ENGLISH SULPHATE OF AMMONL, in casks.

SUPER-PHOSPHATE OF LIME, high grade, in barrels.

GERMAN POTASU SALTS, German test 35 per cent. Sulphate of Potash, in bags.

40 per cent. ACTUAL POTASH, in casks or barrels.

MURIATE OF POTASH, or CHLORIDE OF POTASSTUH, in bags, not below 80 per cent.

NITRATE OF POTASH, in barrels, either Crude or Refined.

STRICTLY PURE GROUND BONE, in barrels. (Purity guaranteed.) SULPHATE OF SODA, ground, in barrels.

NITRATE OF SODA, in original bags, as imported.

AGRICULTURAL SALT.

SALT CAKE, in bulk.

FITRE CAKE, in bulk.

IAAND PLASTER, in barrels.

SULPHATE OF MAGNESIA.

ORGANIC NITROGENOUS HATTER.

PELUVIAN GUANO purchased on commission.

POTATO FERTLLIER, prepured expressly for the Potato Crop, under the formula of Geo. B. Forrester. This article is put up in barrels.

COTION FERTLIZER, in barrels, under formula of GEo. B. ForRESTER.

WINTER WHEAT FERTILZER, in barrels, uncler formula of GEO. B. Forrester.

Our SPECIAL FERTILIERS for particular crops have given excellent satisfaction.

DSF We sell only prime goods.

\section{H. J.}




\title{
PURE BONE DUST,
}

\section{FOR FERTILIZING.}

For Sale by Peter Cooper's Glue Factory,

$$
\text { No. } 17 \text { BURLING SLIP, }
$$

\author{
Now York City.
}

W. M. HABIRSHAW, F. C. S.,

\section{CHEMICAL ENGINEER

ANALYTICAL CHEMIST,

No. 36 NEW STREET,

New York City, 


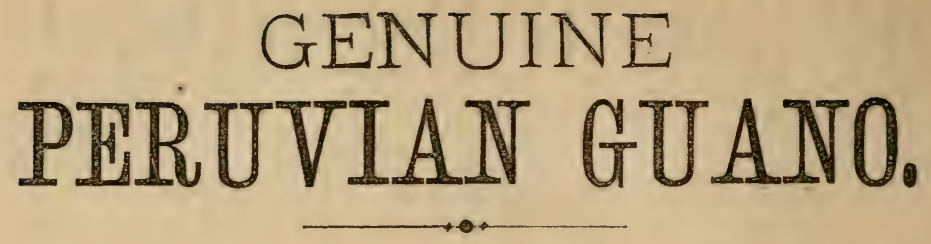

New York, Septeimber 1st, 1874.

I have the pleasure to inform the agricultural community that the special agency established for the sale of Genuine Peruvian Guano, in small or large lots, at the same price at which it may be sold by Messrs. Hobson, Hurtado $\&$ Co., the sole agents of the Peruvian Government in this country, has met with great success so far.

Verbal reports and numerous letters, received daily at this Agency, subject to the perusal of those interested, express entire satisfaction with the Guano sold by me last spring. Farmers and country dealers are finding out that the Guano imported now is as good as it was until adulterated by unscrupulous jobbers in such a manner that many consumers were obliged to abandon its use. As, however, the knowledge of this Agency has spread, they are availing themselves of this opportunity to obtain again the genuine article.

By instructions of the Peruvian Government, their Agents here have advanced the price of Guanape Guano from this date to sixty-two dollars and fifty cents ( $\$ 6250)$, gold, per ton of $2240 \mathrm{lbs}$, gross, establishing at the same time a new scale of discounts, the lowest being of $50 \mathrm{c}$. on parcels from 50 to 100 tons, and the highest $\$ 400$ on 500 tons and over. As usual, they will not sell in lots of less than ten tons.

Under this new arrangement I am enabled to fill orders for lots of Ten Tons and upwards, at less price. than the Agents of the Peruvian Government, I will, as heretofore, supply quantities under Ten Tons at the same rate as chal'gea by them.

Full particulars given in circular mailed free on application.

P. O. Box 120 .

R. BACAZAR, No. 53 Beaver St.; New York.

\section{REFERENCES BY PERMISSION}

Messrs. Hobson, Hurtado \& Co., Financial Agents of the Peruvian Government, $\check{2} 2$ Wall Street, New York.

Moses TAYLor, Pres. National City Bank, 52 Wall Street, New York.

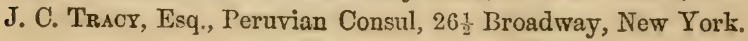




\title{
A BOOK OF INSTRUCTION FOR EVERY FARMER AND HORTICULTURIST.
}

\section{THE NEW FARMER'S GUIDE:}

\author{
SHOWIYG $\mathrm{BX}$
}

EXPERIMENTS OF THE TRIAL FARMS IN EUROPE, TIIAT WITI A JEDICIOUS APPLICATION OF

\section{CHEMICAL FERTILIZERS,}

THE YIELD OF THE PRINCIPAL AGRICULTURAL CROPS MAY BE DOUBLED OR TREBLED;

ALSO GIVIXG

SIMPLE AND EASY METHODS

FOR TIIE

NITRIFICATION OF THE SOIL.

MATHIAS SCHROEDER.

NEW YORK:

BAKER \& GODWIN, PRINTERS, No. 25 PARK Row. 



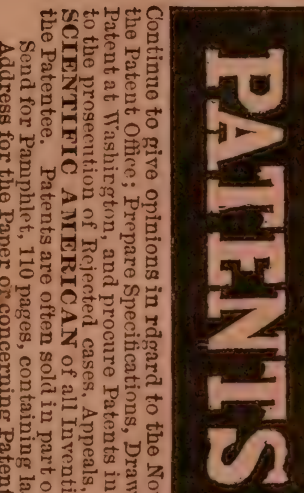

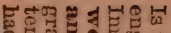
品吉过

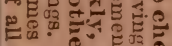

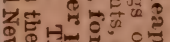
告 ๓

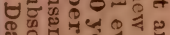

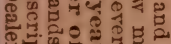

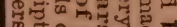

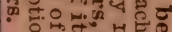

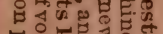
울. $\Phi_{0}$ -

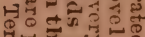
봉ำ

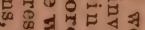
답

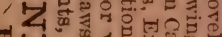
壮

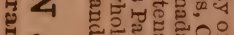

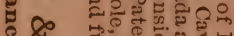

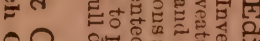

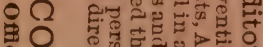

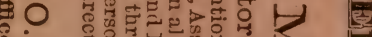
8 \& W

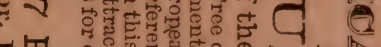
$\Rightarrow$ है

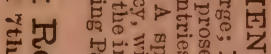

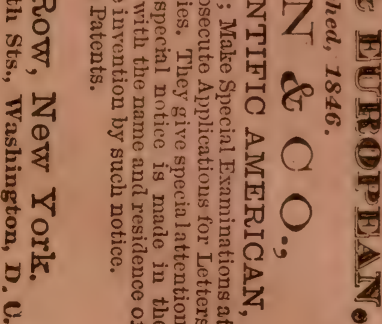

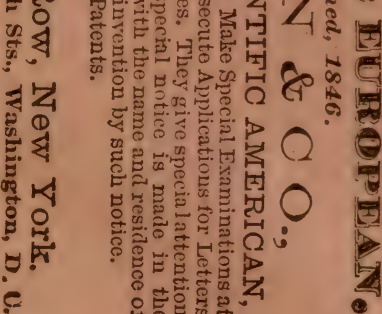
की is 35 政 o: ?. के क्ष

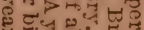

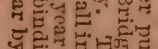

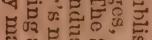

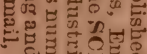

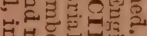

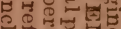

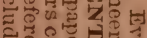

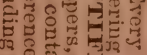

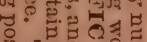

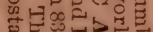
कै

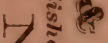

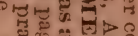

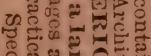

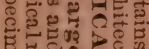

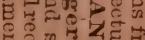
हैं क्ष की

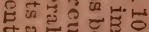
둔 कृ ? स द्ध 당.

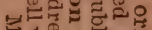

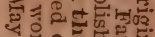

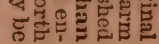

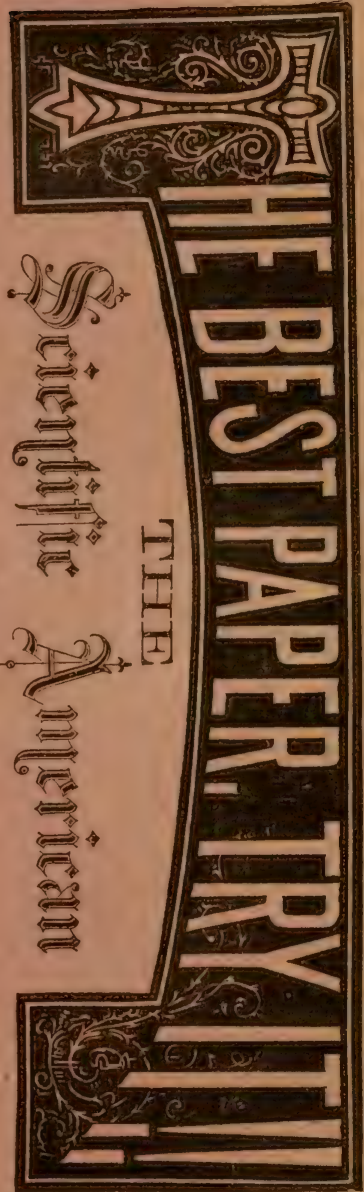









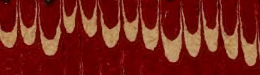

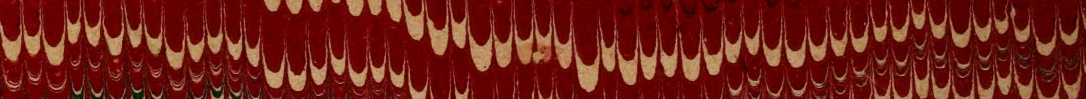
Co $y=-2=0$ Gy 20. are and

ar w How

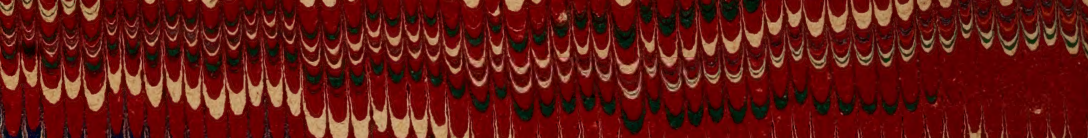
ger a. _. . .

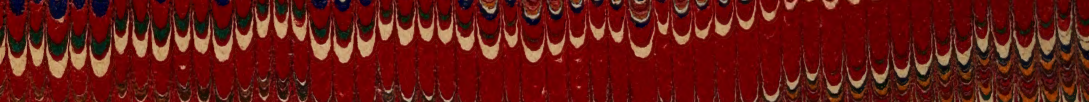
Whallow

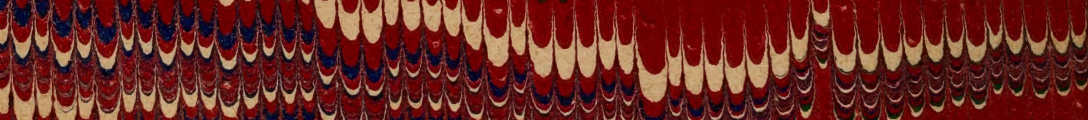

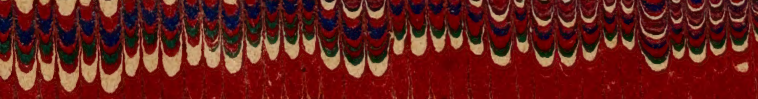

Whall minnmovila Ee 
a

Meres

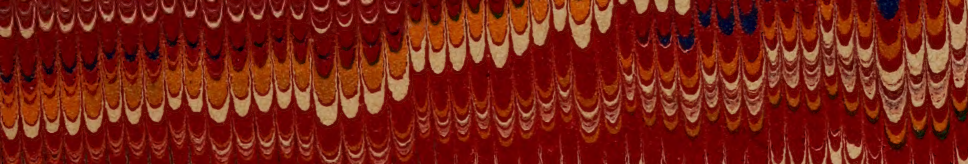

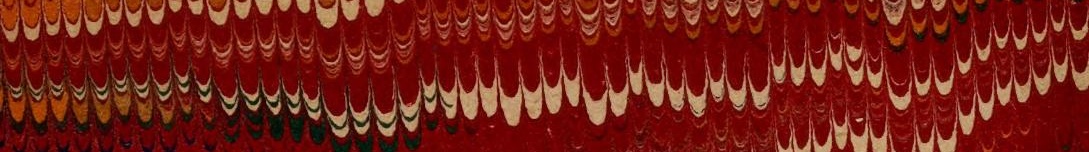

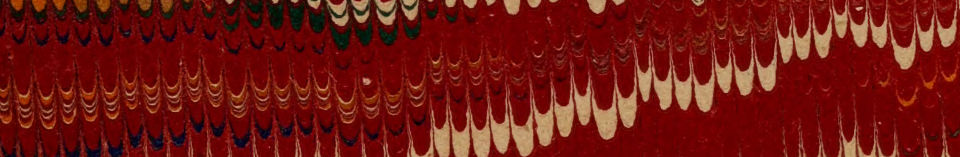

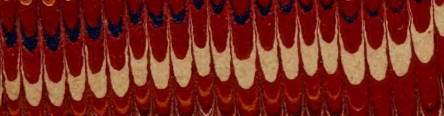

WNO ce

why or Ceveve ger $y=9$

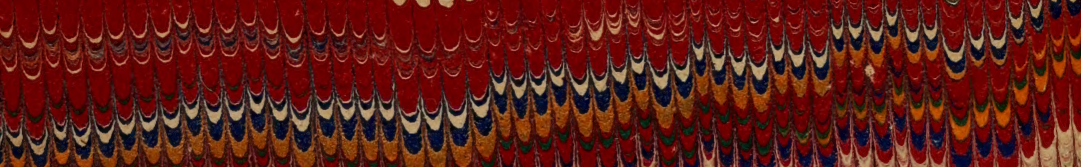
Y T. boy ge y a

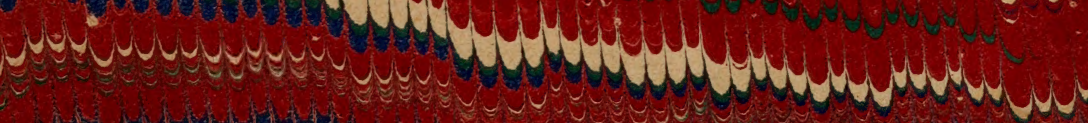




\section{LIBRARY OF CONGRESS}

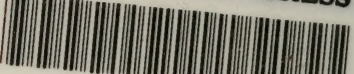

$$
0002755576 \text { ? }
$$

